\title{
Integrated chemo- and biostratigraphic calibration of early animal evolution: Neoproterozoic-early Cambrian of southwest Mongolia
}

\author{
M. D. BRASIER*, G. SHIELDS $\dagger$, V. N. KULESHOV $\ddagger \&$ E. A. ZHEGALLO \\ * Department of Earth Sciences, Oxford University, Parks Road, Oxford OX1 3PR, UK \\ $\dagger$ Geologisches Institut, Sonneggstrasse 5, ETH-Zentrum, CH-8092, Switzerland \\ $\ddagger$ Geochemical Institute, Russian Academy of Sciences, Moscow, Russia \\ $\S$ Palaeontological Institute, Russian Academy of Sciences, Moscow, Russia
}

(Accepted 18 March 1996)

\begin{abstract}
Five overlapping sections from the thick Neoproterozoic to early Cambrian sediments of western Mongolia were analysed to yield a remarkable carbon-isotope, strontium-isotope and small shelly fossil (SSF) record. Chemostratigraphy suggests that barren limestones of sequences 3 and 4, which lie above the two Maikhan Uul diamictites, are post-Sturtian but pre-Varangerian in age. Limestones and dolomites of sequence 5, with Boxonia grumulosa, have geochemical signatures consistent with a postVarangerian (Ediacarian) age. A major negative $\delta^{13} \mathrm{C}$ anomaly (feature 'W') in sequence 6 lies a short distance above an Anabarites trisulcatus Zone SSF asemblage with hexactinellid sponges, of probable late Ediacarian age. Anomaly ' $\mathrm{W}$ ' provides an anchor point for cross-correlation charts of carbon isotopes and small shelly fossils. Trace fossil assemblages with a distinctly Cambrian character first appear in sequence 8 (Purella Zone), at the level of carbon isotopic feature 'B', provisionally correlated with the upper part of cycle $\mathrm{Z}$ in Siberia. A paradox is found from sequence 10 to 12 in Mongolia: Tommotian-type SSFs continue to appear, accompanied by Nemakit-Daldynian/Tommotian-type ${ }^{87} \mathrm{Sr} /{ }^{86} \mathrm{Sr}$ ratios but by increasingly heavy $\delta^{13} \mathrm{C}$ values that cannot be matched in the Tommotian of eastern Siberia. The steady rate of generic diversification in Mongolia also contrasts markedly with the Tommotian 'diversity explosion' in eastern Siberia, which occurs just above a major karstic emergence surface. One explanation is that sequences 10 to 12 in Mongolia preserve a pre-Tommotian portion of the fossil record that was missing or removed in eastern Siberia. The Mongolian sections certainly deserve an important place in tracing the true course and timing of the 'Cambrian radiation'.
\end{abstract}

\section{Introduction}

Over the last decade, increasing interest in events across the Precambrian-Cambrian boundary has highlighted the need for a high-resolution chronostratigraphic framework. At present, this framework is often taken from sections on the Siberian platform, despite the selection of the Precambrian-Cambrian boundary stratotype in southeastern Newfoundland (Landing, 1994; Brasier, Cowie \& Taylor, 1994). These Siberian sections have the advantage of being relatively flat-lying and undeformed, with richly fossiliferous carbonates amenable to carbon and strontium isotope stratigraphy. Recent work has certainly illustrated the potential of the Siberian carbon isotopic record as a standard for global correlation of lower Cambrian stages (e.g. Magaritz, Holser \& Kirschvink, 1986; Magaritz, 1989; Magaritz et al. 1991; Kirschvink et al. 1991; Pokrovsky \& Missarzhevsky, 1993; Bowring et al. 1993; Brasier, Khomentovsky \& Corfield, 1993; Brasier et al. 1994a; Brasier et al. 1994b; Ripperdan, 1994; Knoll et al. 1995a; Pelechaty, Kaufman \& Grotzinger, in press). Latterly, it has also been shown that the Siberian Platform carries an important ${ }^{87} \mathrm{Sr} /{ }^{86} \mathrm{Sr}$ record (Derry et al. 1994; Nicholas, 1996; Kaufman et al. 1996).

Evidence is emerging, however, for a substantial break in the stratigraphic record of the Siberian Platform, at the base of the Tommotian Stage (Knoll et al. 1995b). An erosional, karstic surface can be traced in dolostones beneath this level across much of Siberia (Khomentovsky \& Karlova, 1993). This karstic surface is followed by an abrupt change in lithology that variously includes richly fossiliferous basal Tommotian (Khomentovsky \& Karlova, 1993; Rozanov, 1992) or middle Tommotian (Vidal, Moczydłowska \& Rudavskaya, 1995), and even volcaniclastic conglomerates (Bowring et al. 1993). Carbon isotopic values show a very abrupt negative shift across this disconformity in eastern Siberia (Brasier, Khomentovsky \& Corfield, 1993) though deposition may have continued in northern Siberia, to lay down carbonates with very positive values (Knoll et al. 1995b). Further evidence for this gap in eastern Siberia includes a rapid shift in ${ }^{87} \mathrm{Sr} /{ }^{86} \mathrm{Sr}$ towards less radiogenic values across the Nemakit-Daldynian/Tommotian boundary (Derry et al. 1994; Nicholas, 1996).

The carbonate-dominated successions of the Zavkhan basin in western Mongolia hold potential for testing, correlating and complementing this Siberian Neoproterozoic and Cambrian record. This region is suggested to have lain adjacent to the Siberian Platform in the terminal Neoproterozoic to Cambrian (Şengör, Natal'in \& Burtman, 1993), and the sedimentary and 
palaeontological records of the two areas appear broadly similar (Khomentovsky \& Gibsher, 1996, this issue). There are some important distinctions, however. (1) Mongolian strata previously assigned to the NemakitDaldynian to Tommotian are some ten times thicker than those seen in the eastern or northern Siberian Platform. (2) The Mongolian rocks can also be traced downwards, through a continuous succession of carbonates, to the top of a Neoproterozoic diamictite (Maikhan Uul Member: Lindsay et al. 1996b, this issue). (3) Archaeocyathan sponges first appear in the early Tommotian of Siberia but are unknown until putative late Atdabanian in southwest Mongolia (Voronin et al. 1982; Astashkin et al. 1995). (4) Biomineralized trilobites radiated in the early Atdabanian of Siberia but are as yet unreported from the lower Cambrian of southwest Mongolia (Astashkin et al. 1995).

Russian palaeontologists have provided a wealth of fossil data that allow correlation between successions in western Mongolia and Siberia (e.g. Amantov, 1963; Bezzubetsev, 1963; Markova, Korobov \& Zhuravleva, 1972; Markova, 1975; Korobov \& Missarzhevsky, 1977; Missarzhevsky, 1977; Korobov, 1980). A pilot study of the Salaany Gol section suggested correlations with the base of the Tommotian, Atdabanian and Botomian stages in Siberia (Voronin et al. 1982). Subsequent work on other sections (e.g. Voronova et al. 1986; Endonzhamts \& Lkhasuren, 1988; Gibsher \& Khomentovsky, 1990; Gibsher et al. 1991; Dorjnamjaa \& Bat-Ireedui, 1991; Dorjnamjaa et al. 1993; Esakova \& Zhegallo, 1996; Ushatinskaya, 1995) has allowed further characterization, including recognition of the earlier, NemakitDaldynian Stage of Siberia (Dorjnamjaa \& Bat-Ireedui, 1991, p. 124; see also Khomentovksy \& Gibsher, 1996, this issue). In this paper, we add further data to the fossil record and consider objective methods for correlations into Siberia and beyond.

It has recently been suggested that the base of the Nemakit-Daldynian stage may approximate to the base of the Cambrian System in the Newfoundland stratotype (e.g. Brasier, 1992; Bowring et al. 1993). The position of the Precambrian-Cambrian boundary in Mongolia and elsewhere is, however, still open to debate for two main reasons: the stratotype in Newfoundland is unsuitable for carbon or strontium isotopic correlation (Brasier, Anderson \& Corfield, 1992); and the Phycodes pedum ichnofossil assemblage which defines it cannot be correlated with precision (Goldring \& Jensen, 1996, this issue; Lindsay et al. $1996 a$, this issue). We have, provisionally, taken the base of the Cambrian System at the first appearance of Cambrian-type ichnofossil assemblages in sequence 8 , but we acknowledge that it may lie lower.

\section{Field work}

The well-exposed gorge and mountain sections of the Zavkhan basin were sampled on two separate excursions: during the 21 st Joint Soviet-Mongolian Palaeontological Expedition (Zhegallo \& Zhuravlev, 1991) and again

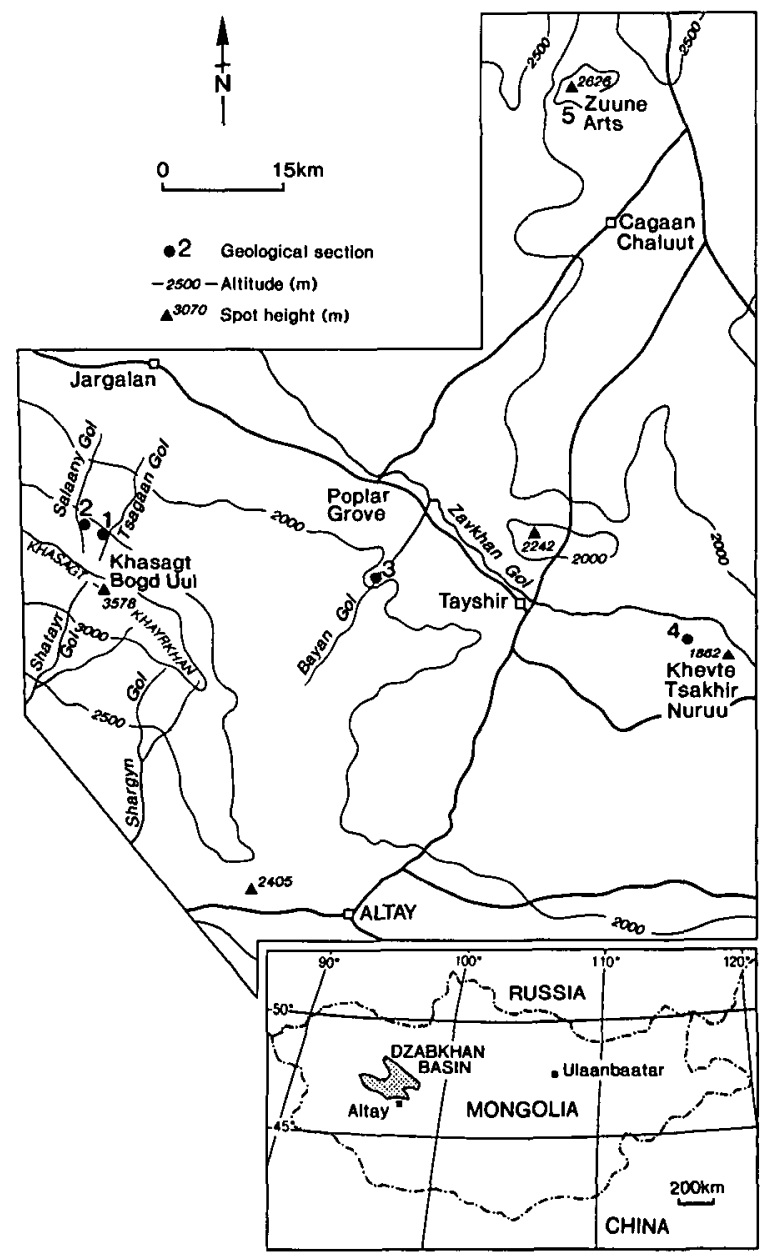

Figure 1. Map showing the location of sampled sections 1 to 5 , in relation to major physiographic features and human settlements. (1) Tsagaan Gol gorge, which lies close to (2) Salaany Gol ridge; (3) Bayan Gol gorge, which lies c. $35 \mathrm{~km}$ east; (4) Khevte-Tsakhir-Nuruu ridge, which lies c. $30 \mathrm{~km}$ eastsoutheast of Tayshir; (5) Zuune Arts ridge, which lies $c .70 \mathrm{~km}$ north of Tayshir and $65 \mathrm{~km}$ southwest of Uliastay.

during the Joint IGCP Project 303-Mongolian Academy of Sciences expedition (Dorjnamjaa et al. 1993). Five previously documented sections were selected for research (see Fig. 1). Correlation in the field was achieved using the lithological markers outlined by Gibsher et al. (1991, fig. 3), the maps of Khomentovsky \& Gibsher (1996, this issue) and the sequence boundaries of Lindsay et al. (1996a, this issue).

\section{Samples and methods}

\section{3.a. Carbon isotopes}

In this study we report on some 319 carbon isotope analyses from the Oxford laboratory and a further 123 from Moscow. The Moscow laboratory used a stepwise decomposition of carbonates in orthophosphoric acid to separate the extraction of $\mathrm{CO}_{2}$ from calcite and dolomite. Each sample was ground to powder, and then plunged into the acid and decomposed for one hour at $25^{\circ} \mathrm{C}$. The 
liberated $\mathrm{CO}_{2}$ gas was then collected and removed for isotopic analysis. This portion of gas was assumed to correspond, broadly, to the product of calcite decomposition (Walters, Claypool \& Phillip, 1972). The decomposition temperature was then heightened to $100^{\circ} \mathrm{C}$ and the sample was kept in for a further one hour to complete the decomposition process. The second portion of the gas was assumed to correspond, broadly, to the product of decomposition of less soluble materials, in this case, of dolomite (e.g. Rosenbaum \& Sheppard, 1986). Massspectrometry measurements were performed using a domestically manufactured MI-1201B mass spectrometer. Reproducibility of replicant measurements was no lower than $0.25 \%$. Relative amounts of calcite and dolomite were then determined by the volume of the rejected gas. Measurements were made against the PDB standard for $\delta^{13} \mathrm{C}$ and SMOW scale for $\delta^{18} \mathrm{O}$, calibrated against an in house standard. Conversion of the oxygen isotopic results, from SMOW to the PDB scale, was therefore necessary for comparison with results from the Oxford laboratories and earlier results, using the following formula derived from Friedman \& O'Neill (1977):

$$
\delta^{18} \mathrm{OPDB}=\frac{\delta^{18} \mathrm{OSMOW}-30.86}{1.03086}
$$

Samples returned to Oxford were largely studied as stained thin sections to determine composition. Wellpreserved rock chips were submitted to the Age Laboratory for preparation by Julie Cartlidge. Fine-grained micrite or microspar was selectively drilled from the most homogeneous regions (to avoid mixed components, veins and vugs) to form a powder, which was then cleaned using $\mathrm{H}_{2} \mathrm{O}_{2}$ and $\left(\mathrm{CH}_{3}\right)_{2} \mathrm{CO}$ and dried for 30 minutes at $60^{\circ} \mathrm{C}$. The samples were then reacted with purified orthophosphoric acid at $90^{\circ} \mathrm{C}$, using a VG Isogas PRISM mass spectrometer, attached to an on-line VG Isocarb preparation system. This method is rapid and easy to use, but no discrimination is possible between calcite and dolomite components in a mixed sample. Reproducibility of replicant standards was better than $0.1 \%$. Calibration to the PDB standard via NBS 19 and Cambridge Carrara Marble was performed daily using the Oxford in-house (NOCZ) Marble Standard.

\section{3.b. Strontium isotopes}

Over two hundred samples were collected by GS in 1993 in parallel with collection for carbon isotope analysis by MDB. Stained thin-sections were made for all samples and studied petrographically. Some 100 samples were then chosen for preparation and analysis. With a few exceptions, dolostones, impure limestones (that is, $<85 \%$ acetic acid soluble) and samples with oxygen isotopic values more negative than $-10 \%$ PDB were considered unsuitable for analysis and avoided. The exceptions included stratigraphic intervals where more suitable carbonates were not available. Here, a few dolostones were examined by dissolution in $<5 \% \mathrm{HCl}$. Trace element concentrations of $\mathrm{Sr}, \mathrm{Rb}, \mathrm{Mn}, \mathrm{Fe}$ and $\mathrm{Mg}$ in carbonates were measured using a Perkin Elmer atomic absorption spectrometer on weak acetic acid soluble fractions. The same acetic acid leachates were also used for the Sr isotope work. Samples whose $\mathrm{Sr}$ contents were unusually low for any particular stratigraphic level were not routinely analysed for their strontium isotope composition because low $\mathrm{Sr}$ content was considered to give the best indication of excessive diagenetic exchange of strontium. Such a selection procedure helped to ensure that only those samples most likely to have retained a sea-water $\mathrm{Sr}$ isotopic signature were measured at each stratigraphic level.

Reproducibility for $\mathrm{Mn}$ and $\mathrm{Fe}$ ppm was good $(<5 \%)$ whereas that for $\mathrm{Sr}$ was irregular $(<10 \%)$. All ${ }^{87} \mathrm{Sr} /{ }^{86} \mathrm{Sr}$ ratios were corrected for the decay of ${ }^{87} \mathrm{Rb}$ based on the decay constant of $\mathrm{Rb}\left(1.42 \times 10^{-11}\right.$ : Steiger \& Jaeger, 1977). This had only a minor influence on the final ratio, due to the low concentrations of $\mathrm{Rb}$ and the relatively high concentrations of $\mathrm{Sr}$ in the carbonates. Only one sample, Bay S1a, was significantly affected by this correction. Results were largely obtained in two laboratories (Institute of Geology, ETH Zürich and CGS, Strasbourg, CNRS), although a small number of reconnaisance samples were also run for us by Martin Whitehouse in the Department of Earth Sciences, Oxford. No significant difference could be detected between these laboratories with respect to standard values or double measurements of the same sample. Sr isotopes were measured on a Finnegan MAT 261 multicollector at the ETH Zürich, (long-term mean NBS 987: $0.710245 \pm 7 ; n=13,2$ s.e.) and at the CGS, Strasbourg on a VG Sector multicollector, (long-term mean NBS 987: 0.710254 $\pm 4, n=73,2$ s.e., and short-term mean over the period of measurement: $0.710249 \pm 6 ; n=4,2$ s.d.). At Oxford, a few samples were measured on a VG 54E single collector; NBS 987 gave $0.710257 \pm 6, n=10,2$ s.e., with comparable errors and reproducibility to those above. All our values are close to 0.710242 and 0.710246 obtained from NBS-987 by Nicholas (1996) and slightly higher than 0.710171 obtained by Derry et al. (1994). Data mentioned in the text have been normalized to the relatively common NBS 987 standard value of 0.71025 and are cited to the fourth decimal place only.

Isotopic results and other geochemical or petrographic data are made available in tabular form in the Appendix: Table 1 shows data for strontium isotopes, Tables 2 to 7 data for carbon and oxygen isotopes.

\section{Component and diagenetic signals}

\section{4.a. Carbon isotopes}

Variability in $\delta^{13} \mathrm{C}$ may be due not only to temporal changes in sea-water chemistry but also to changes in carbonate components and lithofacies through time (see, e.g. Grant, 1992). To test this, we sampled the Zuune Arts section, where rhythmic alternations occur between four limestone biofacies (Fig. 2; see Wood, Zhuravlev \& 
Chimed Tseren, 1993). These show no correlation with $\delta^{13} \mathrm{C}$ values, though $\delta^{18} \mathrm{O}$ values do tend to be heaviest in oolitic limestones.

A separate concern involves the admixture of dolomite and calcite components in many carbonates from the Tsagaan Oloom Formation. Dolomite may be enriched by as much as $2 \%$ at $25^{\circ} \mathrm{C}$ relative to calcite in empirical experiments (Sheppard \& Schwarcz, 1970), but in practice the differences are generally much smaller than this (see Kaufman \& Knoll, 1995). As mentioned above, some attempts were made by the Moscow laboratory to separate these components. The data do not suggest, however, that carbonate mineralogy has a major influence upon the $\delta^{13} \mathrm{C}$ record.

A related concern is that temporal variation in $\delta^{13} \mathrm{C}$ may be masked by carbonate heterogeneity, brought about by mixing between 'primary' signals from the sediment matrix and diagenetic signals from vugs, veins and cement. To test for heterogeneity, we drilled pairs of subsamples from the matrix, each some $10 \mathrm{~mm}$ or more apart, on specimens from the Tsagaan Gol, Salaany Gol and Bayan Gol sections (see, e.g. Fig. 3). A good correla- tion was found between the sample pairs for $\delta^{13} \mathrm{C}$ (Fig. 3a) and $\delta^{18} \mathrm{O}$, though there is a wider dispersion in the latter (Fig. 3b). Such results suggest that carbon isotopic variation within each sample of matrix is, for the most part, relatively minor.

Previous studies have shown that oxygen isotopes are relatively prone to isotopic exchange with meteoric and burial waters during diagenesis, since these contain more of the lighter isotope ${ }^{16} \mathrm{O}$ and are likely to have a higher temperature (see, e.g. Hudson, 1977). Carbon isotopes are less vulnerable, but exchange may also take place, with isotopically lighter ${ }^{12} \mathrm{C}$ liberated by the decay of organic matter in meteoric waters or within the sediment (see, e.g. Irwin, Curtis \& Coleman, 1977). This problem has proven greatest in nodular-concretionary limestones, argillaceous limestones, and thin limestone beds within clastic strata (e.g. the 'temperate' carbonates of southeastern Newfoundland: Brasier, Anderson \& Corfield, 1992). None of the sampled Mongolian carbonates are of this type. Carbonates associated with phosphorites may also show ${ }^{13} \mathrm{C}$ depletion (see, e.g. Brasier et al. 1990). While such horizons do occur at intervals through the

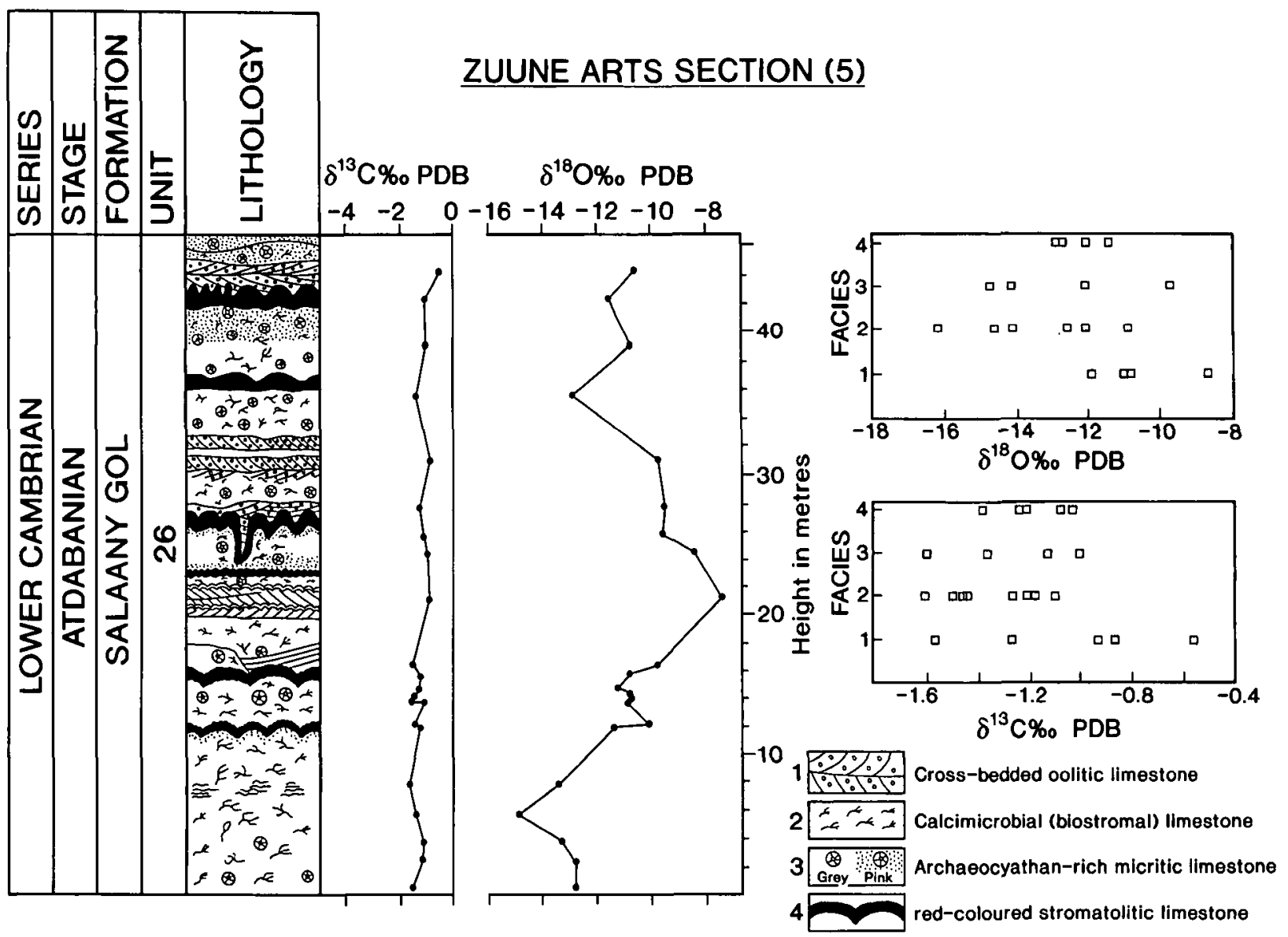

Figure 2. Carbon- and oxygen-isotope stratigraphy of the lower Salaany Gol Formation at Zuune Arts ridge. At right are shown plots of carbon- and oxygen-isotopic ratios in relation to facies divisions 1 to 4 , which correspond to shallowing upward cycles from subtidal oolite banks to peritidal stromatolites (see Wood, Zhuravlev \& Chimed Tseren, 1993, for detailed account). There is no clear relationship between lithofacies and $\delta^{13} \mathrm{C}$ values; ${ }^{18} \mathrm{O}$ tends to be depleted in some limestones beneath shallow to emergent horizons. Unit numbers from Zhegallo \& Zhuravlev (1991). Key as for Figure 5. 
lower Cambrian in Mongolia, only one yielded a highly discordant negative result and this has been excluded from the $\delta^{13} \mathrm{C}$ summary curve.

Diagenetic modification of the $\delta^{13} \mathrm{C}$ signal may be indicated by plotting the covariance between $\delta^{13} \mathrm{C}$ and $\delta^{18} \mathrm{O}$ values in a given section (see, e.g. Brasier, Khomentovsky \& Corfield, 1993). Figure 3c provides such a plot for the Tsagaan Gol data set. Such a wide scatter does not indicate a systematic modification of the whole section by diagenesis. Figure $3 d-h$ represents finer scale studies on adjacent samples, intended to explore the influence of diagenesis during emergence at sequence boundaries. Some covariant shifts are apparent on a minor scale, and these are noted below. Allen \& Matthews (1982) have shown that not only ${ }^{13} \mathrm{C}$ depletion but also ${ }^{18} \mathrm{O}$ enrichment takes place beneath karstic surfaces. In the Mongolian samples, there is a tendency for $\delta^{18} \mathrm{O}$ to increase through a sequence towards its upper boundary and then suffer depletion just below and above the boundary. This can best be explained, however, by a greater influence of burial diagenesis on the more-clastic and therefore more-porous sediments in the lower parts of each sequence. With some exceptions discussed below, the carbon signals do not appear to have been reset by sequence-related diagenesis.

Although examples with strongly negative $\delta^{18} \mathrm{O}$ values appear to be numerous in Mongolia, the $\delta^{18} \mathrm{O}$ and $\delta^{13} \mathrm{C}$ fluctuations are seldom correlated through time (e.g. Figs $5,7-10)$. This is so, even in samples which yield extremely negative $\delta^{18} \mathrm{O}$ values $(>-15 \%$ ). Even so, we regard the following kinds of sample as likely to yield 'suspect', diagenetically modified $\delta^{13} \mathrm{C}$ values: those with $\delta^{18} \mathrm{O}$ values below $-15 \%$, with $\delta^{13} \mathrm{C}$ values below $-6 \%$, or showing conspicuous ferroan carbonate phases in the matrix (Brasier, Anderson \& Corfield, 1992; Brasier et al. 1994b). Such 'suspect' samples are separately noted in Figures 11 to 13 and Tables 2 to 7 . Inspection of the data shows that such 'suspect' values have little impact on the overall stratigraphic trends and that the $\delta^{13} \mathrm{C}$ values discussed below are likely to reflect, for the most part, initial variations in the $\delta^{13} \mathrm{C}$ of Neoproterozoic to Cambrian seawater.

\section{4.b. Strontium isotopes}

No single geochemical or textural indicator has proved to be an infallible test for the degree of preservation of primary $\mathrm{Sr}$ isotopic signatures in ancient carbonates. In addition to petrographic and stable isotopic screening, the relative abundances of $\mathrm{Mn}, \mathrm{Fe}$ and $\mathrm{Sr}$ have been used as indicators of post-depositional alteration (see, e.g. Brand \& Veizer, 1980; Derry, Kaufman \& Jacobsen, 1992; Derry et al. 1994; Nicholas, 1996). Such studies have taken the greatest confidence in ${ }^{87} \mathrm{Sr} /{ }^{86} \mathrm{Sr}$ values obtained from samples that are not dolomitized (that is, with low $\mathrm{Mg} / \mathrm{Ca}$ ratios), that have $<0.6 \mathrm{Mn} / \mathrm{Sr},<3.0 \mathrm{Fe} / \mathrm{Sr}$ and that yield the lowest ratio for a given interval. In this study, we follow these guidelines with the caution that the $\mathrm{Mn} / \mathrm{Sr}$ and $\mathrm{Mg} / \mathrm{Ca}$ concentrations do not appear to be consistent indicators of post-depositional alteration (e.g. Fig. 4a, e).

In order that only calcite and not dolomite (where present) was measured, weak $<5 \%$ acetic acid was used to dissolve the calcite and the reaction was carried out very rapidly. It was regarded as unnecessary that all the calcite present should dissolve. This 'rapid reaction' technique was intended to avoid excess leaching of dolomite or clay minerals. Previous studies have shown that dolomite may be dissolved by acetic acid and that this dolomite can have a significant effect on the strontium isotopic composition of the soluble fraction (Derry et al. 1994). A further check on this was made by analysing the concentration of $\mathrm{Mg}$ in the soluble fraction. In general, $\mathrm{Mg}$ concentrations were below $4000 \mathrm{ppm}$ and hence well within the region of normal content for calcite; there was no correlation of ${ }^{87} \mathrm{Sr} /{ }^{86} \mathrm{Sr}$ ratios with $\mathrm{Mg}$ (see, e.g. Fig. 4e).

Strontium may also be incorporated into calcite from surrounding clay minerals during diagenesis. To have some control over this possible effect and the general problem of leaching from non-carbonate detrital minerals, it is important to determine the amount of insoluble residue in the sample. Figure $4 d$ shows a plot of the percentage of sample dissolvable in acetic acid against the $\mathrm{Sr}$ isotopic composition. A few samples showing low percentages of soluble components also display high ${ }^{87} \mathrm{Sr} /{ }^{86} \mathrm{Sr}$ ratios. No sample measured contained more than $2 \mathrm{ppm} \mathrm{Rb}$ in the soluble fraction. This helps us to exclude the possibility that there was any significant leaching of $\mathrm{Rb}$ or $\mathrm{Sr}$ from clay minerals or other detritus. In a few cases to be mentioned later, selected components were drilled and measured to assess sample homogeneity. This did not produce any significant differences in isotopic signal (see Section 5.b.2). Although samples with over $70 \%$ insoluble residue have been regarded as yielding acceptable strontium isotope ratios (e.g. Nicholas, 1996), we have set the rejection level at a more cautious $15 \%$ (Fig. 4d, Table 1).

Interpretation of 'least-altered' samples in the following account must be somewhat arbitrary. Many of the Mongolian samples show remarkably high Srppm concentrations when compared with coeval carbonates studied elsewhere (Fig. 4b; cf. Derry et al. 1994; Nicholas, 1996). We find that those samples with $>550$ Sr ppm tend to plot entirely within the 'least-altered' field for $\mathrm{Fe} / \mathrm{Sr}$ (Fig. 4c, f). Even so, samples with low $\mathrm{Fe} / \mathrm{Sr}$ and high Sr ppm may plot outside the 'least-altered' fields for $\mathrm{Mn} / \mathrm{Sr}$ (Fig. 4a) and for percentage of dissolvable components (Fig. 4d). Perhaps the best indication of a reasonably well-preserved $\mathrm{Sr}$ isotope signature at any one stratigraphic level, therefore, is the clustering of samples with high strontium concentrations (>550 ppm) and low $\mathrm{Fe} / \mathrm{Sr}$ ratios $(<3.0)$ around relatively low ${ }^{87} \mathrm{Sr} /{ }^{86} \mathrm{Sr}$ ratios. Of the 74 samples analysed here, thirty are regarded as satisfying all the rejection criteria discussed above and shown in Figure 4 and Table 1. The others, including those without adequate trace element data, are regarded as yielding 'suspect' values. 

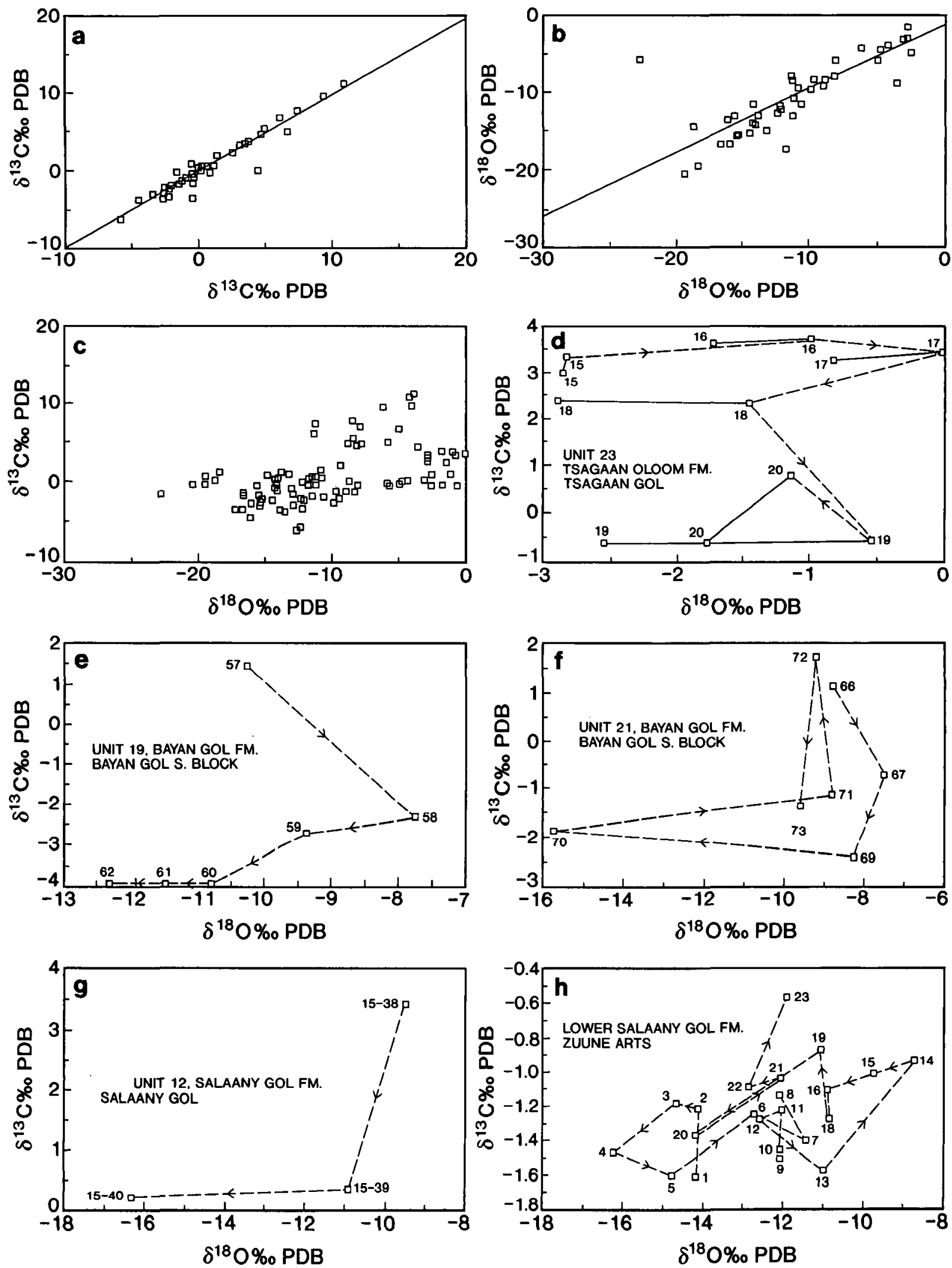

Figure 3. Studies of carbon and oxygen isotopic variation in the Mongolian sections, as described in the text. (a-c), studies of intrasample variability within the Tsagaan Gol-Salaany Gol succession. (a) $\delta^{13} \mathrm{C}$ variation in 48 pairs of samples drilled from carbonates in the Tsagaan Gol-Salaany Gol sections; this shows a strong correlation between sample pairs $\left(r^{2}=0.921\right)$. (b) $\delta^{18} O$ sample pairs from the same sections; this also shows a good correlation between pairs $\left(r^{2}=0.701\right)$. (c) carbon-oxygen isotopic covariance between samples; this shows no clear correlation between carbon- and oxygen-isotopic values $\left(r^{2}=0.241\right)$. $(d-h)$ studies of $C-O$ covariance between adjacent samples at levels associated with suspected emergence. Sample numbers and arrows indicate younging direction in each section. (d) from the upper $24 \mathrm{~m}$ of the Boxonia unit (unit 23) at Tsagaan Gol; sample pairs show great variability of $\delta^{18} \mathrm{O}$, with no clear C-O trend between sample sets $\left(r^{2}=0.001\right)$. (e) from the upper $20 \mathrm{~m}$ of unit 19 , Bayan Gol southern block; samples 60 and 61 are from 


\section{Integrated stratigraphy}

\section{5.a. Tsagaan Gol gorge}

\section{5.a.I. Lithostratigraphy and biostratigraphy}

This gorge section lies about $6 \mathrm{~km}$ north of Khasagt Bogd Uul mountain and $4 \mathrm{~km}$ east-northeast of the Salaany Gol ridge. It exposes a largely unbroken succession from volcanic rocks of the Dzabkhan Formation to carbonates of the lower Bayaan Gol Formation (Fig. 5). An outline of the geology and stratigraphy can be found in Voronin et al. (1982), Gibsher \& Khomentovsky (1990) and Khomentovsky \& Gibsher (1996, this issue).

The Dzabkhan Formation comprises up to $2500 \mathrm{~m}$ of riftogenic calcalkaline volcanic rocks, which elsewhere are known to lie unconformably upon Archaean-Lower Proterozoic crystalline basement (Dorjnamjaa \& BatIreedui, 1991). A Riphean age for these volcanic rocks has been inferred from correlation with the Dunzhugur and Darkhat-Sarkhoy island-arc suites of northern Mongolia and eastern Sayan ( $\mathrm{Rb}-\mathrm{Sr}$ isochrons of 752 Ma: Ilyin, 1982; and 718 $\pm 30 \mathrm{Ma}$ : Buyakayte \& Kuz'michev, 1989). Riphean $\mathrm{Rb}-\mathrm{Sr}$ ages have also been obtained from putative fore-arc and arc-related ophiolite complexes in adjacent domains, as for example at Khantayshir (740 $10 \mathrm{Ma}$ : Lesnov, 1993) and in the Darib region (695 \pm 15 Ma: Baikova \& Amelin, 1994). Younger, Vendian, ages have been obtained from Sm-Nd studies of ophiolite suites at Khan Dharbi (Coleman, 1990 ) and Bayan Khongor (569 Ma Sm-Nd isochron: Kepezhinskas, Kepezhinskas \& Pukhtel, 1991). Poorly substantiated radiometric ages of 777,732 and $725 \mathrm{Ma}$ have been cited for the Dzabkhan volcanic rocks (Dorjnamjaa \& Bat-Ireedui, 1991). Although a middle Riphean age is also inferred by the Dorjnamjaa \& BatIreedui (1991) from intercalated oncolite assemblages, their value for dating is questionable (see Khomentovsky \& Gibsher, 1996, this issue).

Only the upper part of the Dzabkhan Formation is seen in this section, which comprises about $180 \mathrm{~m}$ of acidic to intermediate volcanic rocks, with intercalations of sandstone and conglomerate. These are overlain by the Tsagaan Oloom Formation, which has the Maikhan Uul Member (295 m thick) at its base. The latter comprises lower and upper diamictites with intervening shales, of probable Sturtian or Varangerian age (Lindsay et al. $1996 b$, this issue). A thin bed of mudstones $(0.5 \mathrm{~m})$ marks the relatively abrupt change to carbonates within the Tsagaan Oloom Formation $(c .900 \mathrm{~m}$ ). The lower part comprises organic-rich, fine-grained, laminated limestones and limey dolomites, which pass up into crys- talline limestones in the upper part of unit 19, along with collapse breccias suggestive of karstic dissolution and replacement. Units 20 to 23 are mainly dolomitic carbonates, of which the latter yields the characteristic Vendian stromatolite Boxonia grumulosa (Lindsay et al. 1996a, this issue), and an Ediacaran age is generally inferred (Dorjnamjaa \& Bat-Ireedui, 1991; Khomentovsky \& Gibsher, 1996, this issue). We note, however, that this species is known from below Varanger diamictites in Svalbard (Raaben \& Zabrodin, 1969) and closely related species occur through the Cryogenian (Preiss, 1976). This unit is succeeded by dark, laminated shales, with thin dolomitic, phosphatic and cherty interbeds (unit 24) suggestive of deeper waters, and then by a return to shelf and peritidal carbonate deposition.

Here we report, for the first time, the discovery of hexactinellid sponge spicule assemblages in cherts that lie some $15 \mathrm{~m}$ above the base of unit 25 in Tsagaan Gol (Brasier et al. unpub. data). This early record can be integrated with other published small skeletal fossil (SSF) records from the Salaany Gol, Bayan Gol and Orolchayn Gol sections by means of the lithological and sequence stratigraphic correlations discussed by Khomentovsky \& Gibsher (1996, this issue) and Lindsay et al. (1996a, this issue). In Figure $6 a$ and $b$ we have built upon the synthesis of Khomentovsky \& Gibsher (1996, this issue) by adding records on SSF assemblages outlined in Zhegallo \& Zhuravlev (1991) and Astashkin et al. (1995) and documented in Esakova \& Zhegallo (1996) and Ushatinskaya (1995). As can be seen from Figure 6a, the sponge spicules near the base of unit 25 at Tsagaan Gol correlate with the first appearance datum (FAD) of Anabarites trisulcatus and Cambrotubulus decurvatus in the Orolchayn Gol section (Endonzhamts \& Lkhasuren, 1988). The calcimicrobe Renalcis sp. first appears within unit 25, while calcimicrobe Korilophyton inopinatum appears in unit 27 (Dorjnamjaa et al. 1993). These fossils, and correlation across the region (Khomentovsky \& Gibsher, 1996, this issue), suggest that the start of the Anabarites trisulcatus Zone lies close to the base of unit 25 .

The top of unit 27 contains Osagia oncoids, which are characteristic of the top of the Tsagaan Oloom Formation. The base of the Bayan Gol Formation is marked by shales and thin-bedded, grey to pink argillaceous limestones in the interval between beds 29 and 35 . Numerous small burrows occur in unit 29, while SSFs of the Purella Zone appear in strata correlated with units 34 to 35 (cf. Khomentovsky \& Gibsher, 1996, this issue). Massive limestones of unit $36(103 \mathrm{~m})$ provide a prominent marker, traceable onto the Salaany Gol ridge (Gibsher \& Khomentovsky, 1990). Tommotia sp. and other fossils

\footnotetext{
the same level, $100 \mathrm{~m}$ apart; no overall $\mathrm{C}-\mathrm{O}$ correlation is seen $\left(\mathrm{r}^{2}=0.121\right)$ but samples $58-60,62$ show a stronger correlation $\left(r^{2}=0.877\right)$. (f) from the upper $35 \mathrm{~m}$ of unit 21 at Bayan Gol, southern block; sample 70 shows extreme alteration of $\delta^{18} \mathrm{O}$; overall correlation between $\mathrm{C}$ and $\mathrm{O}$ is poor $\left(\mathrm{r}^{2}=0.076\right)$. (g) from the top $32 \mathrm{~m}$ of unit 12 , Salaany Gol; alteration of $\delta^{18} \mathrm{O}$ is suspected at the top of the bed, but $\delta^{13} \mathrm{C}$ is less affected $\left(r^{2}=0.478\right)$. (h) from the lower $50 \mathrm{~m}$ of the Salaany Gol Formation at Zuune Arts ridge (see Fig. 2); some covariant shifts are apparent but there is no clear trend $\left(r^{2}=0.212\right)$.
} 

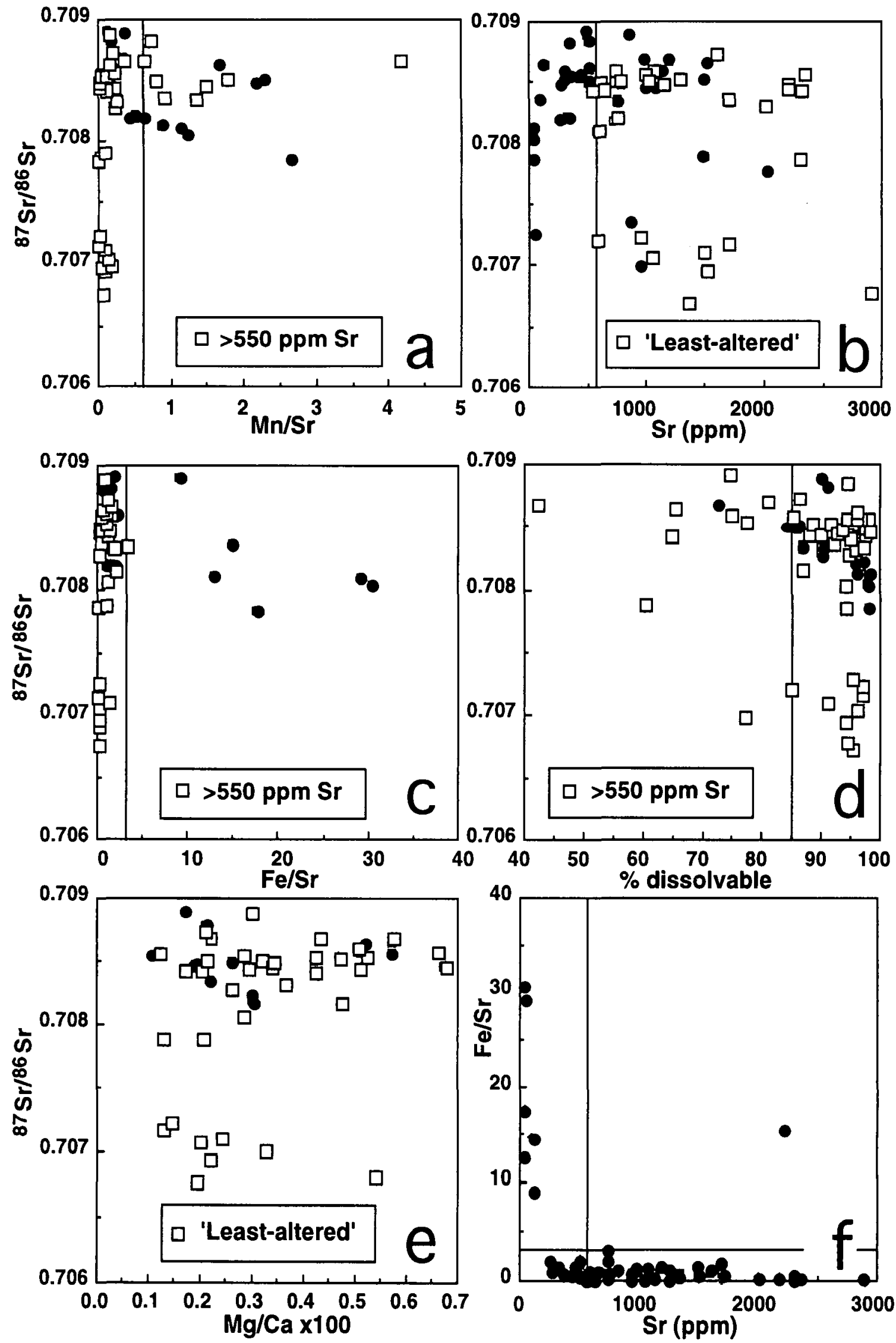

Figure 4. Studies of strontium isotopic variation in the Mongolian sections. (a) $\mathrm{Mn} / \mathrm{Sr}$ versus ${ }^{87} \mathrm{Sr} /{ }^{86} \mathrm{Sr}$ values. (b) $\mathrm{Sr}$ (ppm) versus ${ }^{87} \mathrm{Sr} /{ }^{86} \mathrm{Sr}$ values. (c) $\mathrm{Fe} / \mathrm{Sr}$ versus ${ }^{87} \mathrm{Sr} /{ }^{86} \mathrm{Sr}$ values. (d) per cent dissolvable components versus ${ }^{87} \mathrm{Sr} /{ }^{86} \mathrm{Sr}$ values. (e) $\mathrm{Mg} / \mathrm{Ca}$ ratio versus ${ }^{87} \mathrm{Sr} /{ }^{86} \mathrm{Sr}$ values. (f) $\mathrm{Sr}$ (ppm) versus $\mathrm{Fe} / \mathrm{Sr}$. Straight lines drawn on the diagrams mark an arbitrary division between samples considered more and less likely to contain strontium with sea-water ${ }^{87} \mathrm{Sr} /{ }^{86} \mathrm{Sr}$ ratios. Hence, those samples with $\mathrm{Sr}>550 \mathrm{ppm}, \mathrm{Fe} / \mathrm{Sr}<3.0$, $\mathrm{Mn} / \mathrm{Sr}<0.6$, and per cent dissolvable components $>85 \%$ are considered to be 'least-altered' as opposed to 'suspect' samples. The 
previously thought to be characteristic of the lower Tommotian in Siberia, occur from this level upwards in correlated sections (Voronin et al. 1982; Esakova \& Zhegallo, 1996; Khomentovsky \& Gibsher, 1996, this issue). This problem of the basal Tommotian Stage is discussed in Section 7.

\section{5.a.2. Carbon isotope results}

This succession was sampled for isotopes on two occasions. In 1991, VK sampled using the unit numbers of Voronin et al. (1982) and Zhegallo \& Zhuravlev (1991). This scheme was established for exposures at the foot of the Salaany Gol ridge, however, and not for Tsagaan Gol. Gibsher \& Khomentovsky (1990) have argued that a fault cuts out most of beds 26 to 35 at Salaany Gol. In 1993, MDB therefore followed the latter scheme, and these more recent collections are here used to characterize beds 27 to 35. The two separate sets of results have been collated to give an overall picture of the isotopic record (Fig. 5).

The carbon isotope profile shows a number of features, here identified by capital letters. $\delta^{13} \mathrm{C}$ values rise from negative values (negative anomaly ' $R$ '), to positive values above the top of the upper Maikhan Uul diamictite, in the limestones of sequence 3 (Tsagaan Gol Formation). Relatively stable and very positive values (feature ' $S$ ') occur through the limestones of sequence 4, reaching up to $+11.4 \%$ o near the top. Extremely high $\delta^{18} \mathrm{O}$ values (for the Precambrian) rise through sequences 3 and 4 to a maximum of around zero. A sharp fall in $\delta^{13} \mathrm{C} \%$ (to +2.8$)$ occurs in the lower part of sequence 5 (feature ' $T$ '), which lies above the putative zone of karstic emergence. Slightly higher positive $\delta^{13} \mathrm{C}$ values characterize higher dolomites and limestones (feature ' $U$ '), declining upwards towards the Boxonia unit $(-0.5 \%$; Fig. 5 , fossil marker ' $a$ '). Although changes take place in dolomite and calcite mineralogy at this level (Fig. 5, units 20-23), there is no consistent effect upon $\delta^{13} \mathrm{C}$ values. Nor does the major facies change at the base of sequence 6 have much effect upon $\delta^{13} \mathrm{C}$ (Fig. 5, units 24 to 25). There is, however, a sharp negative shift in $\delta^{18} \mathrm{O}$ at the base of unit 25 .

A continued fall is seen in $\delta^{13} \mathrm{C}$ between beds 25 and 26 , reaching minimal negative values for the EdiacarianCambrian interval ( $-5.3 \%$; negative anomaly ' $W$ '). This contrasts with the preceding fall in $\delta^{18} \mathrm{O}$ mentioned above, since it is part of a prolonged fall in values (rather than an abrupt shift), and it lies up to 150 metres higher in the section, that is, after the phosphatic shale interval rather than coincident with it. Hence it cannot be dismissed as the product of organic degradation associated with phosphogenesis. An oscillatory rise $(-3.9$ to $+1.0 \%$ o $)$ is seen between units 26 and 36 . Here, we provisionally label the positive features as ' $A$ ', 'B' and ' $C$ '. Some of the samples from units 30 to 36 could be regarded as 'suspect' $\left(\delta^{18} \mathrm{O}>-15.0 \%\right.$, Fig. 5, Table 1$)$, but the pattern of 'filtered' data remains similar.

\section{5.a.3. Strontium isotope results}

The Dzabkhan Formation at Tsagaan Gol lacks carbonates, but an opportunity was taken to sample limestones overlying the Lower Proterozoic crystalline basement at Kantayshir, some $240 \mathrm{~km}$ to the east of Govi-Altay. These have been compared in stratigraphic position with the base of the Dzabkhan Formation (Dorjnamjaa \& BatIreedui, 1991) and have yielded to us a single low ${ }^{87} \mathrm{Sr} /{ }^{86} \mathrm{Sr}$ ratio of 0.7057 . This sample contained 1230 ppm Sr, 10 ppm Mn and 123 ppm Fe, which would tend to indicate that little post-depositional trace element exchange has taken place.

Ten samples were collected by GS for strontium isotope analysis through some $50 \mathrm{~m}$ of limestones above the Maikhan Uul diamictite (units 16 to 17). Sr concentrations are very high here (950-2900 ppm) and there is little evidence for post-depositional trace element exchange (see Table 1). Least-altered ${ }^{87} \mathrm{Sr} /{ }^{86} \mathrm{Sr}$ values show a linear rise from 0.7067 to 0.7072 . Four samples were analysed in the Oxford laboratories across the zone of karstic emergence at the top of bed $19(0.7073)$ and into lower bed 20 ( 0.7072 rising to 0.7077$)$. These values are provisional and 'suspect' owing to the lack of trace element data. Six samples from limestones and dolostones beneath the top of the Boxonia grumulosa marker bed (units $20,22,23$ ) yielded 'suspect' ${ }^{87} \mathrm{Sr} /{ }^{86} \mathrm{Sr}$ ratios between 0.7079 and 0.7083 and a single 'least-altered' ratio of 0.7079 . Two samples from units 22 and 23 whose $\mathrm{Sr}$ concentrations were particularly high, but are otherwise 'suspect', also yielded ratios of 0.7079 . Three 'least-altered' samples from the lower part of the Bayan Gol Formation (units 25 to 36 ) yielded ${ }^{87} \mathrm{Sr} /{ }^{86} \mathrm{Sr}$ ratios of 0.7084 to 0.7086 .

\section{5.b. Salaany Gol ridge}

\section{5.b.l. Lithostratigraphy and biostratigraphy}

This section lies $20 \mathrm{~km}$ southwest of Jargalan village, on the northeast slope of the Khasagt-Khayr Khan range (section 2 of Fig. 1). The deep gorge of Salaany Gol defines the western margin of the section, which exposes the limb of a monocline dipping at $40-60^{\circ} \mathrm{SW}$, complicated by minor folds and low amplitude dislocations.

To the east, the succession can be traced down to the Tsagaan Oloom and Dzabkhan formations (Voronin et al. 1982) but, as mentioned above, equivalents of beds 26 to 35 appear to be cut out by a fault (Gibsher \& Khomentovsky, 1990; Khomentovsky \& Gibsher, 1996, this issue). The two sections can be correlated by means

efficacy of using $\mathrm{Sr}(\mathrm{ppm})$ is illustrated by the ornaments on the figures: white squares = samples with $\mathrm{Sr}>550 \mathrm{ppm}$; black dots = 'suspect' samples. 


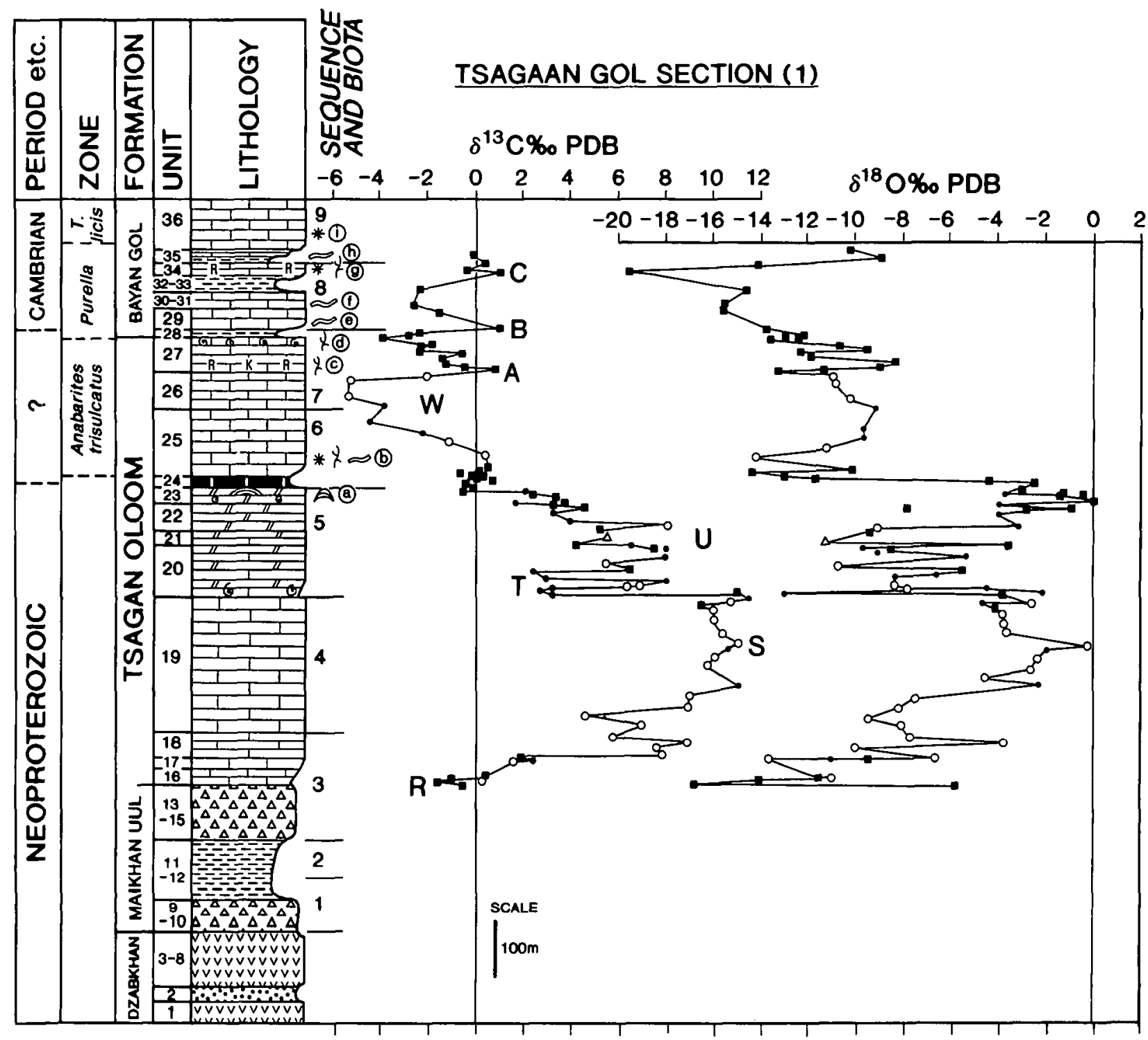

\begin{tabular}{|c|c|c|c|c|c|c|}
\hline 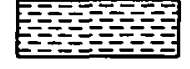 & Mudstone & (1, & Limestone & m & & MOSCOW DATA \\
\hline 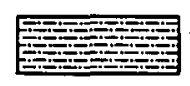 & $\begin{array}{l}\text { Sandstone } 8 \\
\text { Mudstone }\end{array}$ & 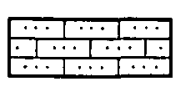 & $\begin{array}{l}\text { Sandy } \\
\text { limestone }\end{array}$ & $\begin{array}{l}6 \\
h\end{array}$ & $\begin{array}{l}\text { Oncoids } \\
\text { Calcimicrobial } \\
\text { algae }\end{array}$ & - Calcite matrix \\
\hline & Sandstone & 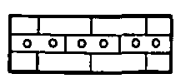 & $\begin{array}{l}\text { Ooolitic } \\
\text { limestone }\end{array}$ & $\begin{array}{l}\mathrm{B} \\
\mathrm{k}\end{array}$ & $\begin{array}{l}\text { Renalcis } \\
\text { Korilophyton }\end{array}$ & - Dolomite matrix \\
\hline : & Conglomerate & 年1 & $\begin{array}{l}\text { Cherty } \\
\text { limestone }\end{array}$ & $\begin{array}{l}\mathrm{E} \\
\otimes\end{array}$ & $\begin{array}{l}\text { Evaporitic } \\
\text { fabric } \\
\text { Archaeocyatha }\end{array}$ & $\begin{array}{l}\text { OXFORD DATA } \\
\text { - Carbonate matrix }\end{array}$ \\
\hline & Volcanics & 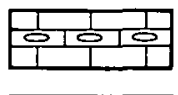 & $\begin{array}{l}\text { Carbonate } \\
\text { breccia }\end{array}$ & 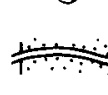 & $\begin{array}{l}\text { Section } \\
\text { omitted }\end{array}$ & $\begin{array}{l}\text { W,O, Isotope cycles } \\
\text { I,II etc }\end{array}$ \\
\hline IIIIII & Dolostone & 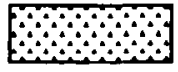 & Diamictite & & $\begin{array}{l}\text { Phosphatic } \\
\text { mudstone }\end{array}$ & * Small skeletal \\
\hline
\end{tabular}

Figure 5. Carbon- and oxygen-isotope stratigraphy of Tsagaan Gol. The suggested positions of carbon isotopic features ' $R$ ' to ' $W$ ' and 'A' to 'C' are shown. Sequence boundaries are from Lindsay et al. (1996a, this issue). Biota first appearance datum (FAD) points are from Dorjnamjaa et al. (1993), Khomentovsky \& Gibsher (1996, this issue), Lindsay et al. (1996a, this issue), as follows: (a) beds with stromatolite Boxonia grumulosa; (b) FAD (first appearance datum) of simple traces and hexactinellid sponge spicules; also SSFs Anabarites trisulcatus, Cambrotubulus decurvatus (both by correlation from Orolchayn Gol); calcimicrobes Botominella lineata, Renalcis; (c) calcimicrobes Renalcis, FAD of Korilophyton; (d) oncoids with Osagia; (e, f, h) simple traces; (g) FAD of SSFs Lopochites sp., Purella cristata, Archaeooides granulatus, Maikhanella multa, Protohertzina sp., Siphogonuchites sp., plus Renalcis; (i) FAD of SSF Tommotia sp. and others at nearby Salaany Gol. The zones are as shown in Figure 6. Unit numbers and lithostratigraphy are from Gibsher \& Khomentovsky (1990), except the Maikhan Uul Member of the Tsagaan Oloom Formation, informally named by Dorjnamjaa et al. (1993, p. 21) and defined by Lindsay et al. (1996b, this issue). 
of the prominent limestone of unit 5 (sensu Voronin et al. $1982=$ unit 7 of Zhegallo \& Zhuravlev, 1991), which is equivalent to unit 36 at Tsagaan Gol.

The western part of the section exposes the most complete and fossiliferous succession through the Bayan Gol, Salaany Gol and Khayrkhan formations. This part of the succession was described in detail by Voronin et al. (1982; palaeontology summarized in English by Brasier, 1989), whose fossil markers are shown in Figures 6 and 7. In this paper we have modified the zones, to take account of new SSF data brought together in Figure $6 a$ and $b$.

The Bayan Gol Formation consists predominantly of sandstones and siltstones, intercalated with three thick limestone beds (units 5, 7 and 12) and numerous thin limestone beds (units 9, 11 and the labelled fossil marker beds) that are traceable across the ridge. Phosphatic layers in the limestones preserve a variety of SSFs used to establish local biozones. The Tiksitheca licis to Ilsanella compressa-Anabarella plana Zones have usually been correlated with the Tommotian of Siberia (e.g. Voronin et al. 1982). Elements typical of the middle Tommotian appear in the lower part of unit 10, towards the top of the Bayan Gol Formation (Voronin et al. 1982; Khomentovsky \& Gibsher, 1996, this issue). Assemblages of the Watsonella crosbyi Zone have been compared with the middle Tommotian of Siberia (Missarzhevsky, 1982) or even the lower Atdabanian (Voronin et al. 1982; Astashkin et al. 1995). The latter interpretation appears to be based upon an isolated record of poorly illustrated acritarchs referred to Dictyotidium priscum, Goniosphaeridium varium and Asteridum tornatum. These would indicate assignment to the Heliosphaeridium dissimilare-Skiagia cilosa assemblage, which is now known to occur at least as low as the middle Tommotian in Siberia (Vidal, Moczydłowska \& Rudavskaya, 1995). Recent work has also shown that the associated SSFs Watsonella crosbyi and Stenothecoides sp. are both known from the basal Tommotian in eastern Siberia (Khomentovsky \& Karlova, 1993).

The top of unit 12 is reddened and overlain by conglomerates of unit 13 (c. $150 \mathrm{~m})$, containing siliceous and calcareous clasts that mark the base of the Salaany Gol Formation. The hiatus at the base of this formation is variously suggested to span the middle to upper Tommotian (Missarzhevsky, 1982) or the mid-Atdabanian (Astashkin et al. 1995). The Salaany Gol Formation is intruded near its base by a sill of pink, coarse-grained granite up to $5 \mathrm{~m}$ wide. The upper part of unit 13 marks a return to limestone deposition, and the first appearance of archaeocyaths of Atdabanian type (Voronin et al. 1982; Astashkin et al. 1995). Unit 14 comprises $270 \mathrm{~m}$ of massive, biohermal limestones with archaeocyaths, interpreted as late Atdabanian (Voronin et al. 1982; Wood, Zhuravlev \& Chimed Tseren, 1993; Astashkin et al. 1995). The formation is capped by up to $11 \mathrm{~m}$ of tabular-bedded limestones with archaeocyaths and SSFs taken to be of late Atdabanian age (e.g. Voronin et al. 1982).

The base of the Khayrkhan Formation (up to $500 \mathrm{~m}$ thick) is an uneven, angular unconformable surface that, elsewhere, cuts down into the Bayan Gol Formation (Voronin et al. 1982, fig. 4). Sediments are predominantly sandy with conglomeratic interbeds (including Neoproterozoic and lower Cambrian clasts) with subordinate siltstones, mudstones and limestones. Archaeocyaths and SSFs occur in the limestone bands (Voronin et al. 1982), but much of this biota appears to have been derived by erosion from underlying units, making it difficult to assess the age of this unit with precision. The appearance of SSFs Mongolodus rostriformis, Lapworthella dentata and Rhombocorniculum cancellatum (Korobov \& Missarzhevsky, 1977; Missarzhevsky, 1977) have suggested a Botomian age for the base (Astashkin et al. 1995).

\section{5.b.2. Carbon and strontium isotope results}

This section was sampled for carbon isotopes by MDB in 1991 and 1993, while the upper part was sampled for $\mathrm{Sr}$ isotopes by GS in 1993. The carbon isotopic profile (Fig. 7) is interrupted by thick units of sandstone. Even so, four broad phases can be distinguished. Positive $\delta^{13} \mathrm{C}$ values (up to $+2.3 \%$ o) are found in unit 5 (feature ' $D$ ') and midunit 7 (here separated as feature ' $E$ ' for reasons discussed below). A shift to negative $\delta^{13} \mathrm{C}$ values in mid-unit 7 is sustained through the thin limestone beds of beds 8 and 9 (down to $-1.9 \%$ ). Positive but oscillatory $\delta^{13} \mathrm{C}$ values are found in beds 10 to 12 (feature ' $F$ ', up to $5.1 \%$ ). Negative values predominate through the upper part of unit 14 and into 15 , although five samples outline a positive excursion (Fig. 7 , at top; -1.1 to $+2.5 \%$, here labelled as feature ' $G$ '). No data are available from beds 13 and lower 14, but this interval was sampled at Zuune Arts, which yielded stable, negative values (c. -0.6 to $-1.6 \%$, Fig. 2).

Seven 'least-altered' samples of carbonates from the lower part of the Bayan Gol Formation (units 5-7) show remarkably consistent ${ }^{87} \mathrm{Sr} /{ }^{86} \mathrm{Sr}$ values of around $0.7084 / 5$ (see Table 1). Five samples from the upper part of the Formation (units 8 to 12) lie between 0.7083 and 0.7088 . Of these, two 'least-altered' samples with very high $\mathrm{Sr}$ concentrations yield 0.7083 .

Two samples ( 5 analyses) from the upper part of the Salaany Gol Formation yielded consistent ${ }^{87} \mathrm{Sr} /{ }^{86} \mathrm{Sr}$ values of between 0.7081 and 0.7082 . An archaeocyath and early diagenetic cement (SG3r and SG3w respectively) were measured separately. Sample SG1 from the upper part of the Salaany Gol Formation was measured three times, to examine sample homogeneity and establish a suitable preparation technique. A further sample, from limestones in the lower part of the Khayrkhan Formation, was measured twice: $\mathrm{KHm}$ (micrite inside a broken archaeocyath) and $\mathrm{KHr}$ (a recrystallized archaeocyath). Both gave a ratio of 0.7083 . From field observations, it is possible that these components may have been reworked from the underlying Salaany Gol Formation. Trace element chemistries for these samples from the top two formations, where measured, cannot rule out the effects 


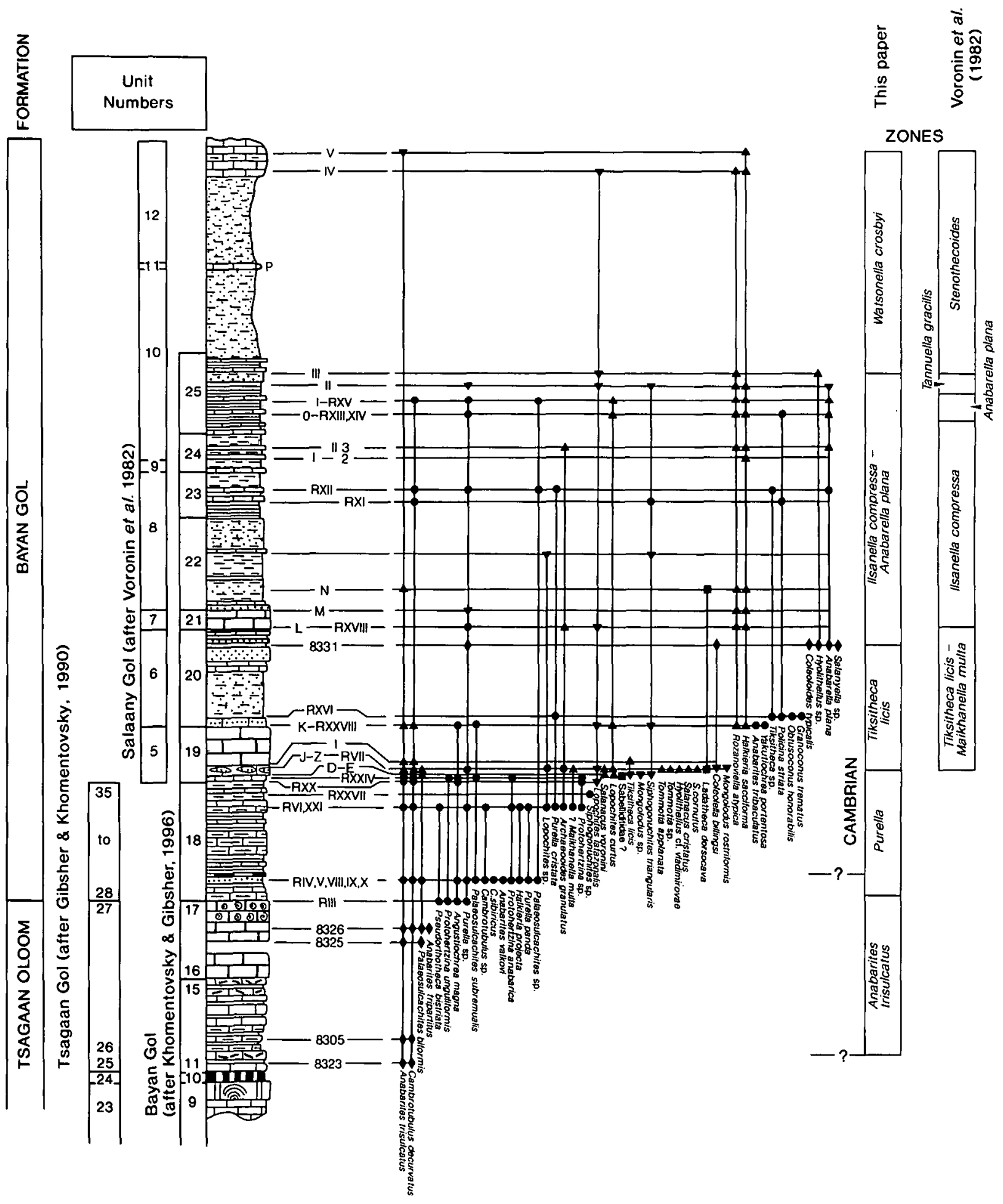

Figure 6. (a, b) Composite range charts for small skeletal fossils through the Neoproterozoic-Cambrian transition of western Mongolia; Anabarites trisulcatus to Tiksitheca licis Zones. These incorporate data from five separate collections: (1) Endonzhamts, in Endonzhamts \& Lkhasuren (1988); (2) Khomentovsky \& Gibsher (1996, this issue); (3) authors in Voronin et al. (1982); (4) Korobov \& Missarzhevsky (1977); (5) Zhegallo \& colleagues (Zhegallo \& Zhurvalev, 1991; Astashkin et al. 1995; Esakova \& Zhegallo, 1995; Ushatinskaya, 1995). The fossil horizons are collated according to the scheme of Khomentovksy \& Gibsher (1996, this issue). Correlation between the units numbers for Bayan Gol (after Khomentovsky \& Gibsher, 1996, this issue), Salaany Gol (after Voronin et al. 1982) and Tsagaan Gol (after Gibsher \& Khomentovsky, 1990) are shown at left. A revised zonal scheme is shown at right, alongside that put forward by Voronin et al. (1982). The first appearance of two main trace fossil assemblages is shown against the $\log$ (after Goldring \& Jensen, 1996, this issue). The Precambrian-Cambrian boundary is provisionally placed at the lowest level with a Cambrian-type trace fossil asemblage. 


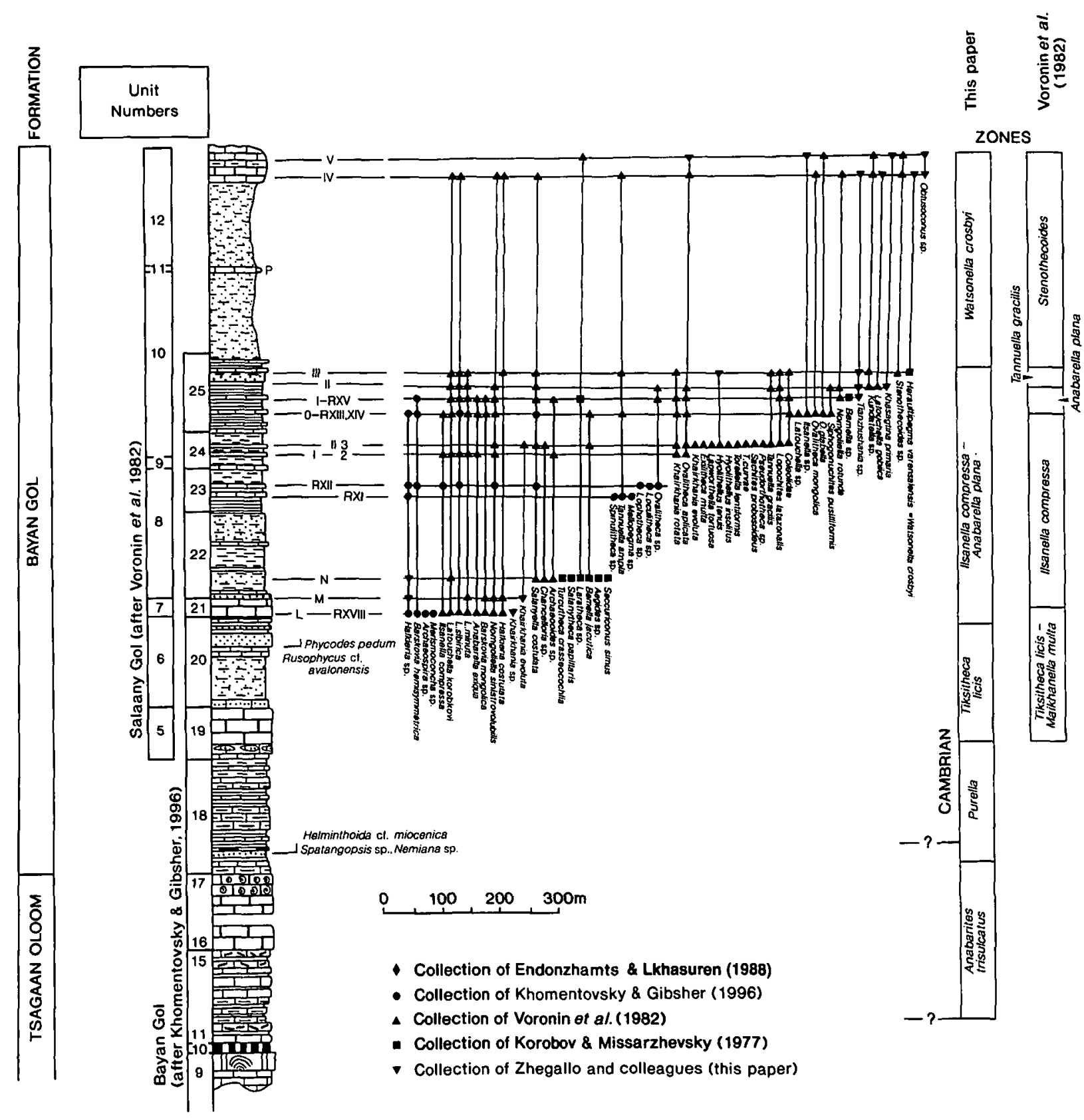

Figure 6. (b) For legend see facing page.

of post-depositional alteration (Table 1) and they are regarded as 'suspect', but the ${ }^{87} \mathrm{Sr} /{ }^{86} \mathrm{Sr}$ values show a broadly consistent picture.

\section{5.c. Bayan Gol gorge}

\section{5.c.I. Lithostratigraphy and biostratigraphy}

The section along Bayan Gol gorge provides a long but much faulted section through the following units: acid volcanic rocks of the Dzabkhan Formation; thin diamictites of the basal Tsagaan Oloom Formation (Maikhan Uul Member); overlying carbonates of the Tsagaan Oloom Formation; and terrigenous-carbonate intercalations of the Bayan Gol Formation. Two separate sets of unit numbering have been used: those of Zhegallo \&
Zhuravlev (1991); and those of Gibsher et al. (1991), followed by Khomentovsky \& Gibsher (1996, this issue).

The lower unit of the Maikhan Uul Member comprises beds of diamictite followed by a unit of coarse-grained arkosic sandstone ( $25 \mathrm{~m}$; Fig. 8, unit 1). The upper diamictite is not visible, either because of poor exposure or because of removal by an unmapped thrust fault (Lindsay et al. 1996b, this issue). The overlying, middle member of the Tsagaan Oloom Formation exposes a thick succession $(<550 \mathrm{~m})$ of interbedded dolomites varying from light-grey to almost black. In the upper member of this formation, dolomites are replaced by limestones (from dark- to light-grey) with black siliceous concretions. The conformably overlying Bayan Gol Formation includes various interbedded limestones (including are- 


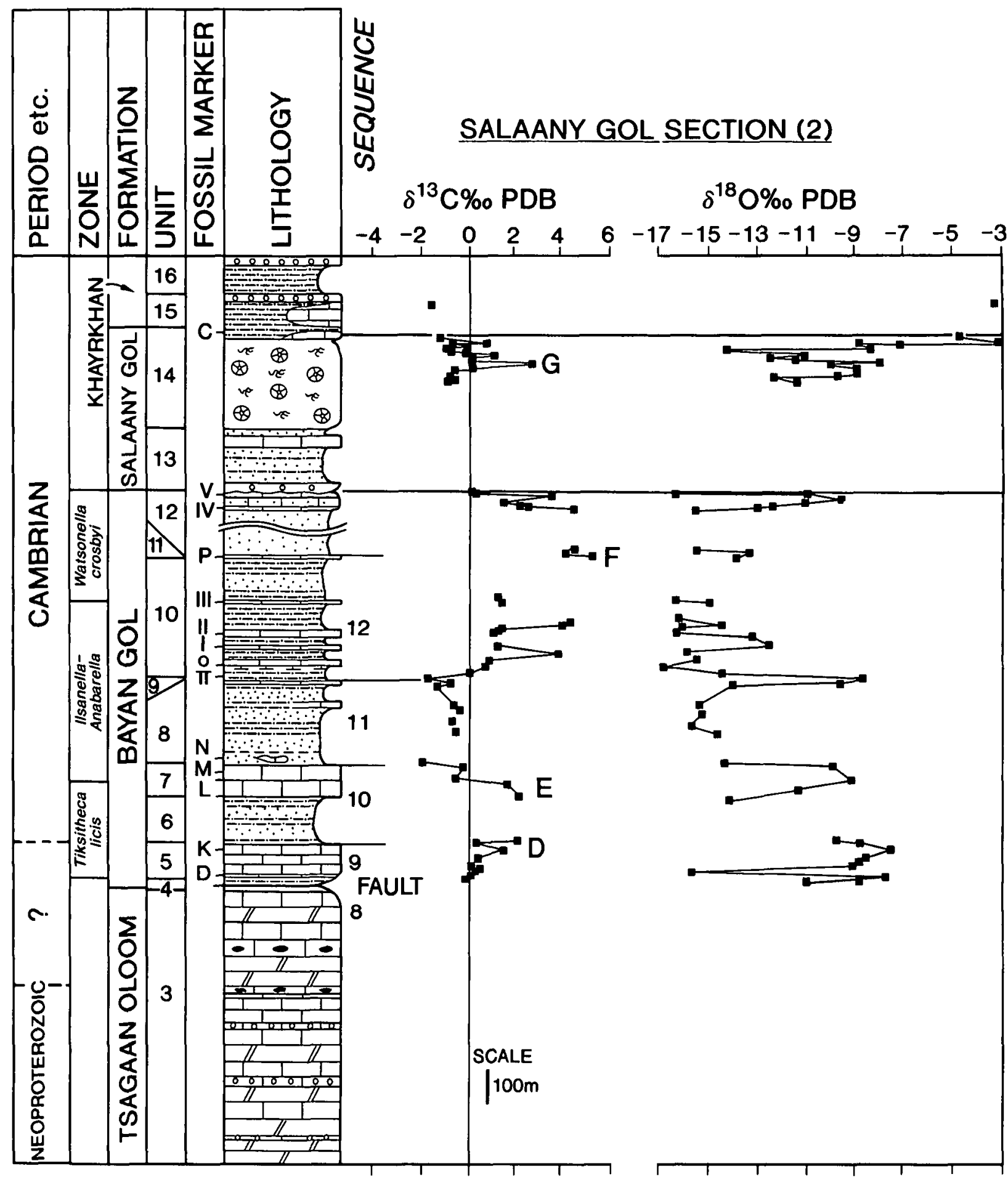

Figure 7. Carbon- and oxygen-isotope stratigraphy of the Salaany Gol ridge section. The suggested positions of carbon isotopic features ' $D$ ' to ' $F$ ' are shown. Sequence boundaries are from Lindsay et al. (1996a, this issue). Fossil markers, unit numbers and formations are from Voronin et al. (1982). Zones as in Figure 6. Key as for Figure 5.

naceous, argillaceous or dolomitic varieties), siliciclastic sandstones and siltstones.

\section{5.c.2. Carbon and strontium isotope results}

Samples from the 'northern block' of Bayan Gol gorge were collected by VK and MDB in 1991. These results are shown in Figure 8, using the ' $\mathrm{ZZ}$ ' unit numbers of Zhegallo \& Zhuravlev (1991). A return to the gorge in
1993 showed that faulting had disturbed the natural succession about their beds 12 and 13 and no reliance could be placed on the 1991 data from this point and above. Figure 8 shows the results of further collecting by MDB and GS in 1993. Beds 8-16 were collected from the 'northern block', up to the fault zone, using the maps and 'GK' unit numbers of Gibsher (in Khomentovksy \& Gibsher, 1996, this issue). Isotopic comparisons between 'GK' units 8-16 and 'ZZ' units 11-12 in Figure 8, suggest 


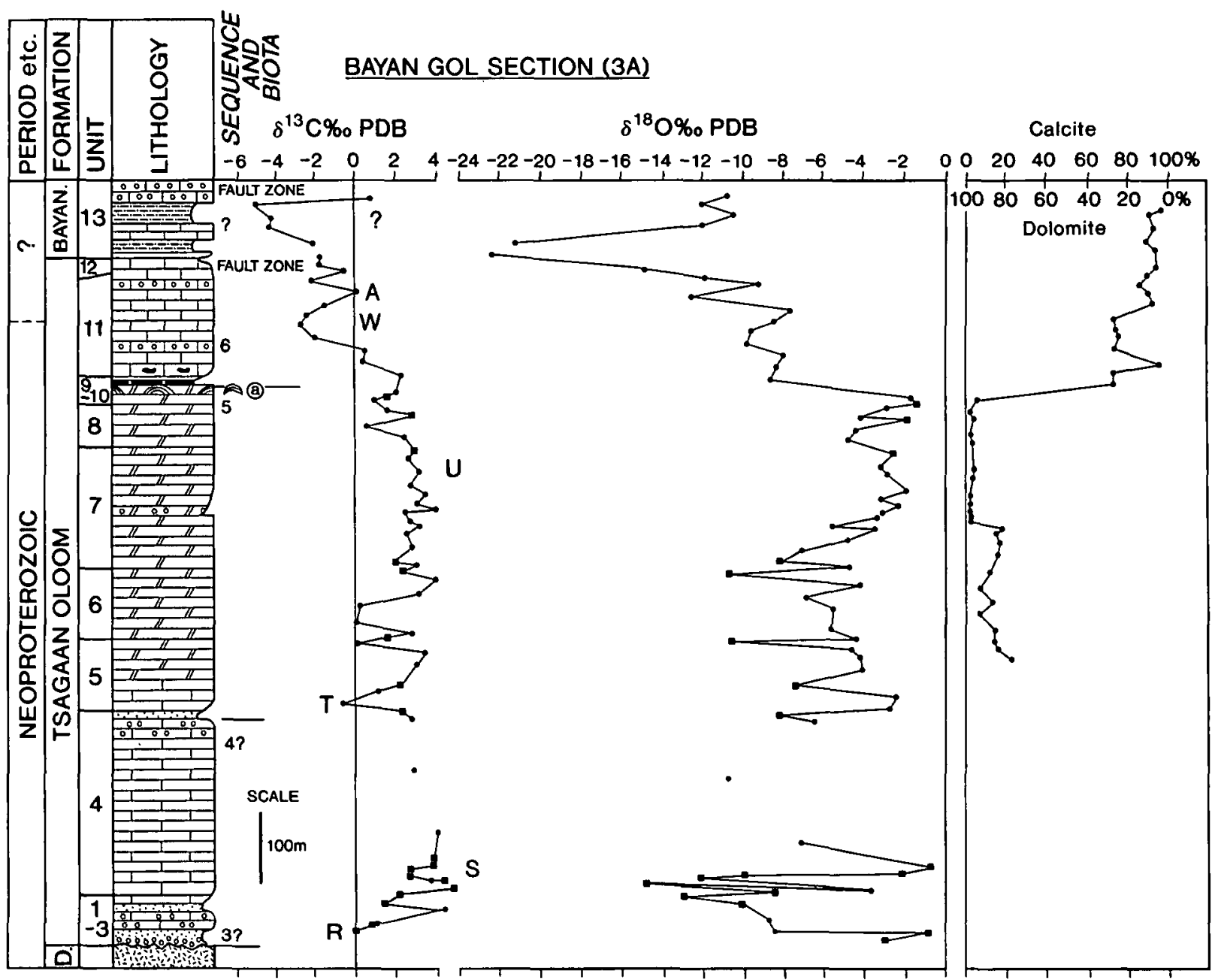

Figure 8. Carbon- and oxygen-isotope stratigraphy of the lower succession at Bayan Gol, northern block. The positions of carbon isotopic features ' $R$ ' to ' $A$ ' are shown. A fault zone disturbs the top of this section. Calcite and dolomite data are differentiated in the upper part only. Column at right shows the shift from dolomite- to calcite-dominant carbonates above the Boxonia grumulosa stromatolite unit (biota datum ' $a$ '). Sequence boundaries are from Lindsay et al. (1996a, this issue). Unit numbers and formations are after Zhegallo \& Zhuravlev (1991). D. = Dzabkhan Formation; BAYAN = Bayan Gol Formation. Key as for Figure 5.

that the isotopic profiles are comparable. The upper part of the section ('GK' units 17-21) was studied in the 'southern block', alongside researches on sequence stratigraphy and trace fossils (Lindsay et al. 1996a, this issue; Goldring \& Jensen, 1996, this issue).

The carbon isotope profiles (Figs 8, 9) show a number of distinct features. $\delta^{13} \mathrm{C}$ rises from low values $(c .0 \%$, top of negative anomaly ' $R$ ') just above the Maikhan Uul diamictite, to positive values ( $4.6 \%$, cf. feature ' $S$ ') in unit 4 of the Tsagaan Gol Formation, followed by values near to zero in units 5 and 6 (cf. feature ' $T$ '). Relatively stable and positive carbon values between 4.0 and $2.0 \%$ occur through units 7 to 9 (feature ' $U$ ').

Carbonates through this section contain a fine-scale mixture of dolomite and calcite grains, with the balance between these shifting abruptly from dolomite to calcite above the base of unit 11 (Fig. 8, at right). This change in mineralogy is accompanied by a negative shift in $\delta^{18} \mathrm{O}$, but there is no abrupt $\delta^{13} \mathrm{C}$ shift. Carbon isotopic ratios continue to decline above this level, reaching low values in negative anomaly ' $W$ ' (c. -2.8\%o). As at Tsagaan Gol, this anomaly comes well above the abrupt negative shift in $\delta^{18} \mathrm{O}$ (Figs 8, 9).

Above this, there is a fall in $\delta^{13} \mathrm{C}$ through the top of the Tsagaan Oloom Formation (top of feature ' $A$ ', unit 17, Fig. 9); a $\delta^{13} \mathrm{C}$ peak at the base of the Bayan Gol Formation (feature ' $\mathrm{B}$ ', unit 18); a drop from the top of unit 18 to the base of unit 19 (upper part of feature ' $\mathrm{C}$ '); and a rise in $\delta^{13} \mathrm{C}$ through unit 19 (feature ' $\mathrm{D}$ ', Fig. 9). The covariant trend in $\delta^{18} \mathrm{O}$ values (Figs $3 \mathrm{e}, 9$ ), and the presence of fenestral calcite, both suggest that meteoric diagenesis may have affected $\delta^{13} \mathrm{C}$ in the upper part of unit 19. No data are available through the thick clastic strata of unit 20 . A $\delta^{13} \mathrm{C}$ peak near the base of unit 21 declines upwards to negative values (feature ' $E$ ', Fig. 9).

With regard to ${ }^{87} \mathrm{Sr} /{ }^{86} \mathrm{Sr}$ values, dolomitic sample Bay Sla was the only sample whose ratio was significantly decreased by the $\mathrm{Rb}$ decay correction. It decreased from 0.7089 to 0.7086 , even though the sample contains little $\mathrm{Rb}$ (1.7 ppm). This $\mathrm{Sr}$ value is considered unreliable 


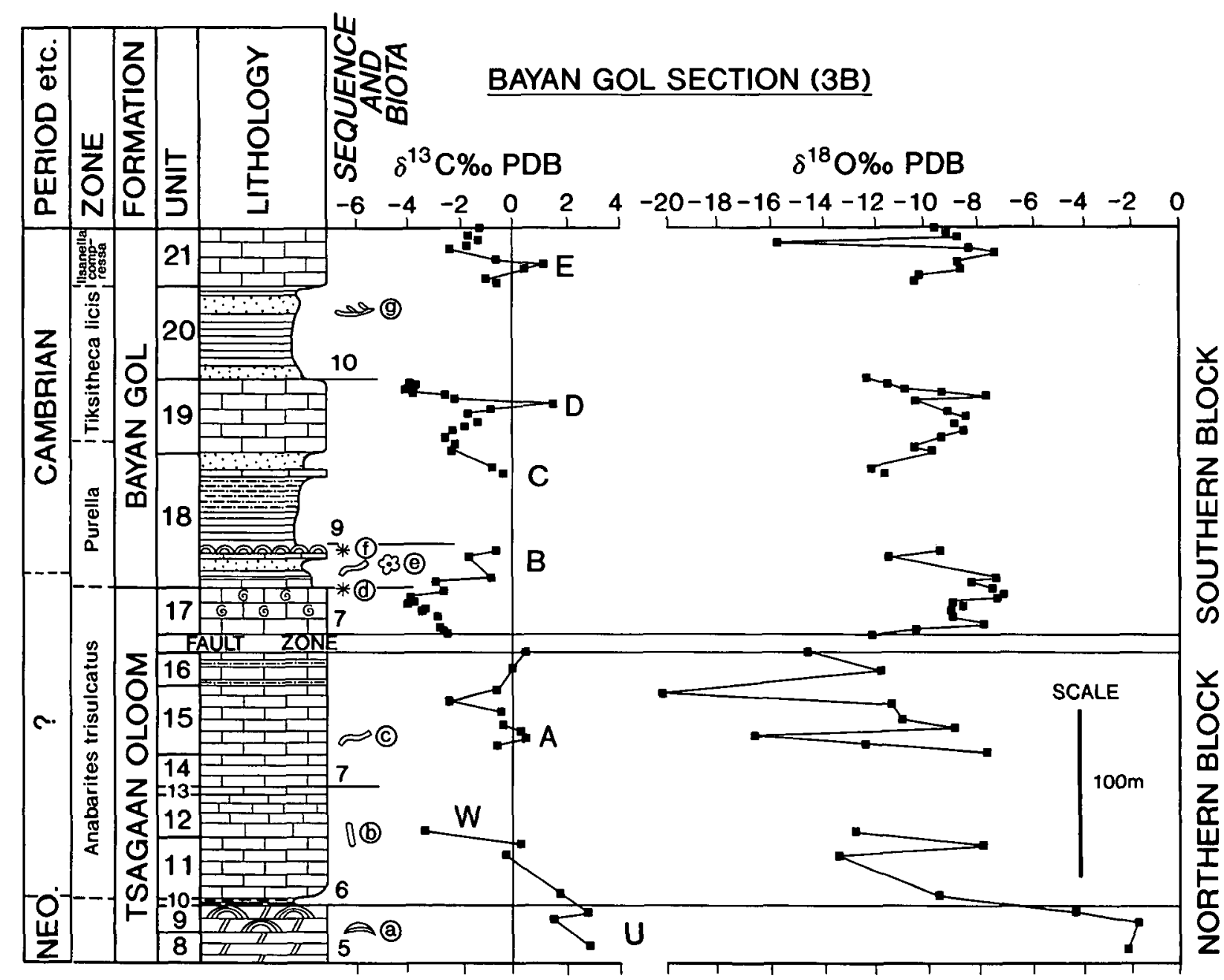

Figure 9. Carbon- and oxygen-isotope stratigraphy of the upper succession at Bayan Gol, northern and southern blocks (section 3 on Fig. 1). Carbon isotopic features ' $U$ ' to ' $W$ ' and 'A' to 'E' are shown. Sequence boundaries are after Lindsay et al. (1996a, this issue). Biota FADs are from Dorjnamjaa et al. (1993), Goldring \& Jensen (1996, this issue), Khomentovsky \& Gibsher (1996, this issue) and Lindsay et al. (1996a, this issue): (a) stromatolite Boxonia grumulosa; (b) FAD of simple burrows, including small, Skolithos-like spar-filled pipes preserved as tubular fenestrae; (c) horizontal meandering burrows; (d) FAD of SSFs Pseudorthotheca bistriata, Protohertzina unguliformis, Purella sp.; (e) FAD of trace fossils Didymaulichnus miettensis, Helminthoida cf. miocenica, Planolites isp., Spatangospsis isp.; (f) FAD of SSFs Cambrotubulus decurvatus, Angustiochrea magna; (g) FAD of trace fossils Cochlichnus isp., Monomorphichnus isp., Palaeophycus tubularis, Phycodes pedum, Rusophycus cf. avalonensis, Taphrhelminthoida cf. meandria. Unit numbers and lithostratigraphy are after Gibsher et al. (1991) and Khomentovsky \& Gibsher (1996, this issue). Zones as for Figure 6. Key as for Figure 5; calcite and dolomite samples undifferentiated.

because of the error associated with such a correction, together with evidence for unsuitable trace element chemistry and high amounts of insoluble residue (Table 1). Consistent, lower values (0.7084-0.7085) were found in samples through overlying units 11 to 14 . Of six samples through unit 17 , one 'least-altered' sample yields 0.7085 , while another from the middle of unit 19 also yields 0.7085 . Of six samples from unit 21 , one 'leastaltered' sample also yields 0.7085 .

\section{5.d. Khevte-Tsakhir-Nuruu (KTN) ridge}

\section{5.d.1. Lithostratigraphy and biostratigraphy}

This section is located c. $30 \mathrm{~km}$ southeast of Tayshir village, on the left bank of the River Zavkhan (section 4 on Fig. 1). Here is exposed a monocline, dipping southeast at $30^{\circ}$ to $40^{\circ}$ and broken into repeated successions by faults. A 'northern block' exposes a thick succession from beneath unit 1 to the top of unit 3. A 'southern block' repeats this succession up to unit 16 without major dislocation. Minor faulting was commonly observed at the boundary between units 1 and 2 (Zhegallo \& Zhuravlev, 1991).

The general succession is shown in Figure 10. The Dzabkhan Formation and the Maikhan Uul Member of the Tsagaan Oloom Formation are not exposed. The faulted base of the Tsagaan Oloom Formation here begins with an unbroken, 350-m-thick succession of dolomites, varying from light-grey to almost black in colour. The Boxonia grumulosa marker unit occurs in the upper part 


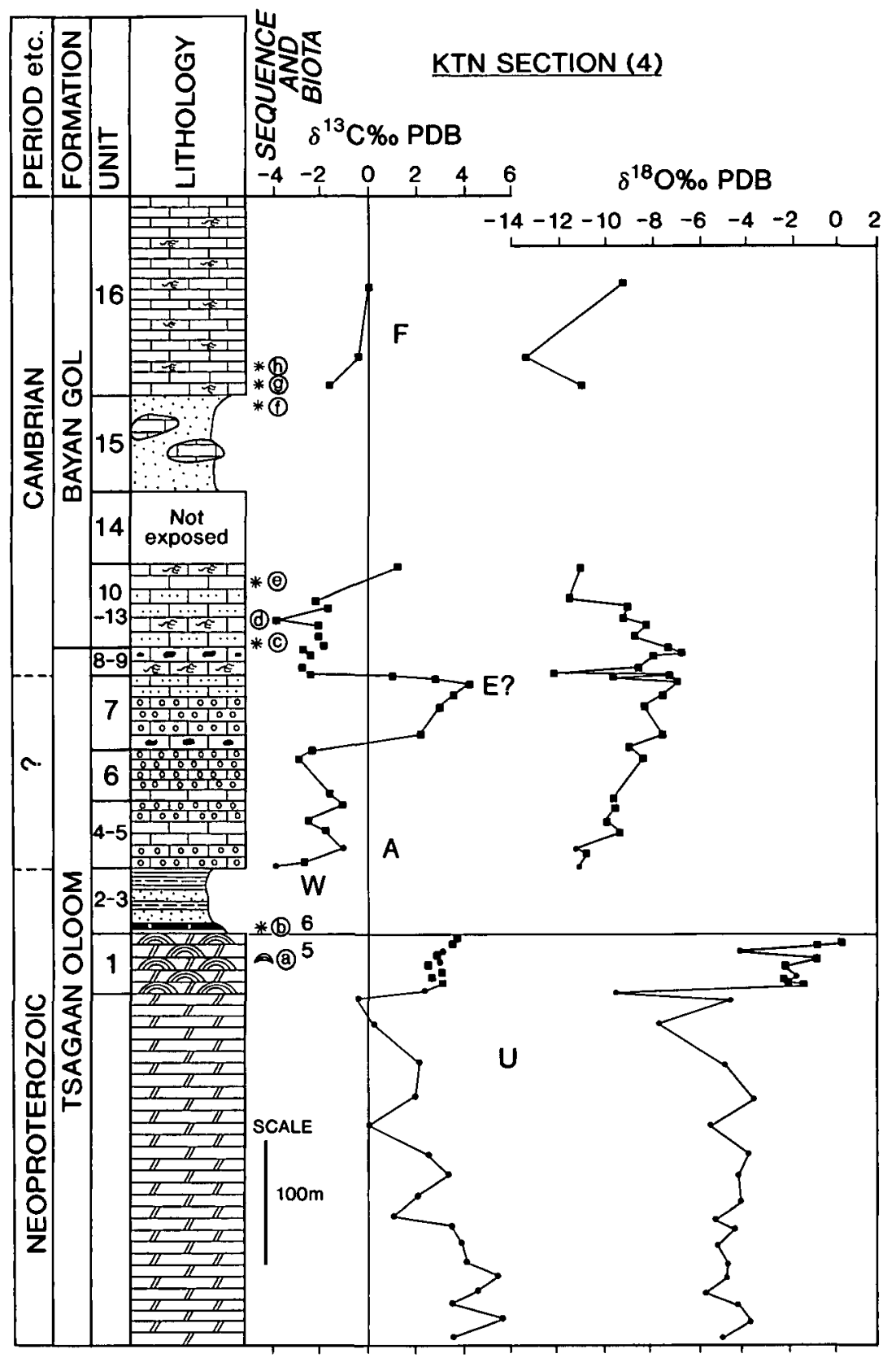

Figure 10. Carbon- and oxygen-isotope stratigraphy of the Khevte-Tsakhir-Nuruu (KTN) ridge section. The positions of carbon isotopic features 'U', 'W', 'A'. 'E?' and 'F' are suggested. Biota FADs are from Zhegallo \& Zhuravlev (1991), Dorjnamjaa et al. (1993) and Esakova \& Zhegallo (1995): (a) stromatolite Boxonia grumulosa; (b) supposed FAD of SSF Anabarites trisulcatus according to Dorjnamjaa et al. (1993); (c) FAD of SSFs Maikhanella multa, Rozanoviella atypica, Cambrotubulus decurvatus, Siphogonuchites sp., Lopochites cf. latazonalis, Archaeooides sp.; (d) FAD of SSFs Latouchella korobkovi, Khairkhania sp., Gonamella sp., Halkieria amorphe; (e) FAD of SSFs Nomgoliella sinistrovolubilis; (f) FAD of SSFs Tannuella sp., Spinulitheca sp., Hyolithellus tenuis; (g) FAD of SSFs Nomgoliella rotundata, Bemella jacutica, Ovalitheca glabella; (h) FAD of SSF Purella sp. Assemblages (d) to (g) have faunas that correlate best with the Ilsanella compressa-Anabarella plana Zone. The unit numbers and formation boundaries are those of Zhegallo \& Zhuravlev (1991). Key as for Figure 5; calcite and dolomite samples undifferentiated.

of the dolomites (unit 1). This is followed by thin siliceous phosphorite (unit 2) reported to contain Anabarites trisulcatus (Dorjnamjaa et al. 1993). Overlying mudstones, siltstones and sandstones (unit 3) are followed by limestones of light- and dark-grey colour, with ooliths and black chert concretions (units 4 to 7). Mixed terrigenous and carbonate rocks, perhaps to be correlated with the Bayan Gol Formation, follow above a local disconformity. Sediments consist of interbedded dark-grey limestones, siltstones and sandstones.

\section{5.d.2. Carbon and strontium isotope results}

Samples for isotopic analysis were collected for study at Moscow by VK, and independently for Oxford by Dr E. Zhegallo and Dr S. Bengtson in 1991. A discrep- 
ancy was found between results from these two samplings, thought to result from confusion over unit numbers. Further collection of the critical interval (unit 7) was therefore undertaken by MDB in 1993. The collated isotopic profiles are given in Figure 10. This easterly section is important for carbon isotope stratigraphy because unbroken carbonate deposition appears to have continued for longer than seen in the west.

Neither the extremely positive $\delta^{13} \mathrm{C}$ values of feature ' $S$ ' nor the low values of feature ' $T$ ' have been encountered in this section. Values up to $c .5 .8 \%$ in the lowest exposed part of the Tsagaan Oloom Formation are compared with feature ' $U$ ' of previous sections. Ratios tend to decline upwards, followed by a reversal of this trend through the Boxonia unit, much as seen at Tsagaan Gol.

A peak of negative $\delta^{13} \mathrm{C}$ values (c. $-3.9 \%$ ) occurs directly above the phosphatic shale, in unit 4 , correlated with negative anomaly ' $W$ '. A positive $\delta^{13} \mathrm{C}$ excursion in unit 7 (up to $+4.3 \%$ ) cannot be matched at this level in other sections. A rapid return to negative $\delta^{13} \mathrm{C}$ values is seen in upper unit 7 to unit 13. An isolated positive $\delta^{13} \mathrm{C}$ value is found in the top of unit 13 , and negative values occur in unit 16.

Four samples of dolomite (KTN1 to KTN4) were analysed for ${ }^{87} \mathrm{Sr} /{ }^{86} \mathrm{Sr}$, from $20 \mathrm{~m}$ below the appearance of Boxonia grumulosa to the top of this marker bed (unit 1). These samples give ${ }^{87} \mathrm{Sr} /{ }^{86} \mathrm{Sr}$ ratios of 0.7079 to 0.7081 . These dolomitic samples must be considered 'suspect', but their strontium isotopic ratios are broadly consistent with each other and concordant with the general stratigraphic trend.

\section{5.e. Zuune Arts ridge}

\section{5.e.1. Lithostratigraphy and biostratigraphy}

This section lies $65 \mathrm{~km}$ southwest of Uliastay, between the granite massifs of Zuune Arts and Barun Arts (section 5 on Fig. 1). The succession exposes a monocline, dipping at $20^{\circ}$ to $40^{\circ}$ and complicated by faults. Only the Salaany Gol Formation was studied here in 1991, although the Tsagaan Oloom Formation $(415 \mathrm{~m})$, with Boxonia grumulosa marker unit, and the Bayan Gol Formation, with Phycodes pedum near the base, are both present (Voronin et al. 1982). Study of this part of the succession was planned in 1993 but prevented by catastrophic flooding which destroyed bridges across the Zavkhan River.

The lower part of the Salaany Gol Formation comprises poorly exposed silty limestones and siltstones (27 $\mathrm{m})$. Above these lie rhythmically bedded units of oolitic, grey to pink archaeocyathan-microbial, and pink to red domal stromatolitic limestones (Fig. 2). The palaeontology of these rocks has been described by Drozdova (1980), Sayutina (1985), Ushatinskaya (1993, 1995), Wood, Zhuravlev \& Chimed Tseren (1993) and Esakova \& Zhegallo (1996). Archaeocyaths give evidence for a late Atdabanian age (Voronin et al. 1983; Wood, Zhuravlev \& Chimed Tseren, 1993). The lithofacies and palaeoecology give evidence for repeated shallowingupward cycles, from subtidal oolite banks, through subtidal calcimicrobial and archaeocyathan biostromes, to reddened stromatolites penetrated by neptunean dykes (see Wood, Zhuravlev \& Chimed Tseren, 1993).

\section{5.e.2. Carbon and strontium isotope results}

Carbon isotope results have been obtained by the Oxford Laboratory from collections made in 1991 (Fig. 2). The $\delta^{18} \mathrm{O}$ values vary widely, with some evidence for ${ }^{18} \mathrm{O}$ depletion in the shallower facies 2 to 4 . The $\delta^{13} \mathrm{C}$ values remain steady and negative throughout (c. -0.6 to $-1.6 \%$ PDB), despite rhythmic changes in facies. Comparable negative $\delta^{13} \mathrm{C}$ values were obtained from the upper part of the Salaany Gol Formation at Salaany Gol (Fig. 7). The only sample so far analysed for ${ }^{87} \mathrm{Sr} /{ }^{86} \mathrm{Sr}$ (ZA-8) yielded a 'least-altered' ratio of 0.7082 . This value is consistent with 'suspect' samples measured from slightly higher in this formation at Salaany Gol (Table 1).

\section{Regional synthesis}

\section{6.a. Carbon chemostratigraphy}

Carbon isotopic data from the sections described above are brought together in Figure 11, alongside correlation of major lithological marker units (Khomentovsky \& Gibsher, 1996, this issue) and sequence boundaries (Lindsay et al. 1996a, this issue).

Sequences 3 to 4 at Tsagaan Gol are characterized by a rise from negative to positive $\delta^{13} \mathrm{C}$ values, which reach up to $11.4 \%$ at one level (Fig. 11, features ' $R$ ' to ' $S$ '). Limestones predominate in this part of the Tsagaan Oloom Formation, and karst-like breccias near the top of sequence 4 may indicate an important episode of emergence. At Bayan Gol, comparable limestones extend through the lowest $350 \mathrm{~m}$ of the formation, and the low $\delta^{13} \mathrm{C}$ values of negative anomaly ' $R$ ' are seen above the Maikhan Uul diamictite, but values in sequence 4 do not exceed $4.6 \%$. This may be because wide sample spacing has led to our missing peak values. An alternative explanation is that erosion (or faulting?) at the top of sequence 4 (or perhaps above the diamictite) has removed feature ' $S$ ' with maximal $\delta^{13} \mathrm{C}$ values, but as yet there is no evidence for this.

The base of sequence 5 at Tsagaan $\mathrm{Gol}$ is marked by a sharp drop in $\delta^{13} \mathrm{C}$ values (to $2.8 \%$ ), followed, mainly, by dolomites whose values do not exceed $8.0 \%$. Much lower values are seen in dolostones to the east, at Bayan Gol $(<4.0 \%)$ and Khevte-Tsakhir-Nuruu (KTN) $(<5.8 \%$ ). This, and the clear differences in the profiles, are best explained by contrasting patterns of sediment accumulation. The interval with oscillatory and negative values (' $T$ ') is thicker at Bayan Gol, thinner at Tasgaan Gol and apparently not sampled at KTN. While the decline in values towards the Boxonia grumulosa bed (' $U$ ') is seen in each section, there are distinct contrasts at the level of this marker: the positive shift at Bayan Gol 


\section{Basal congolomerate}

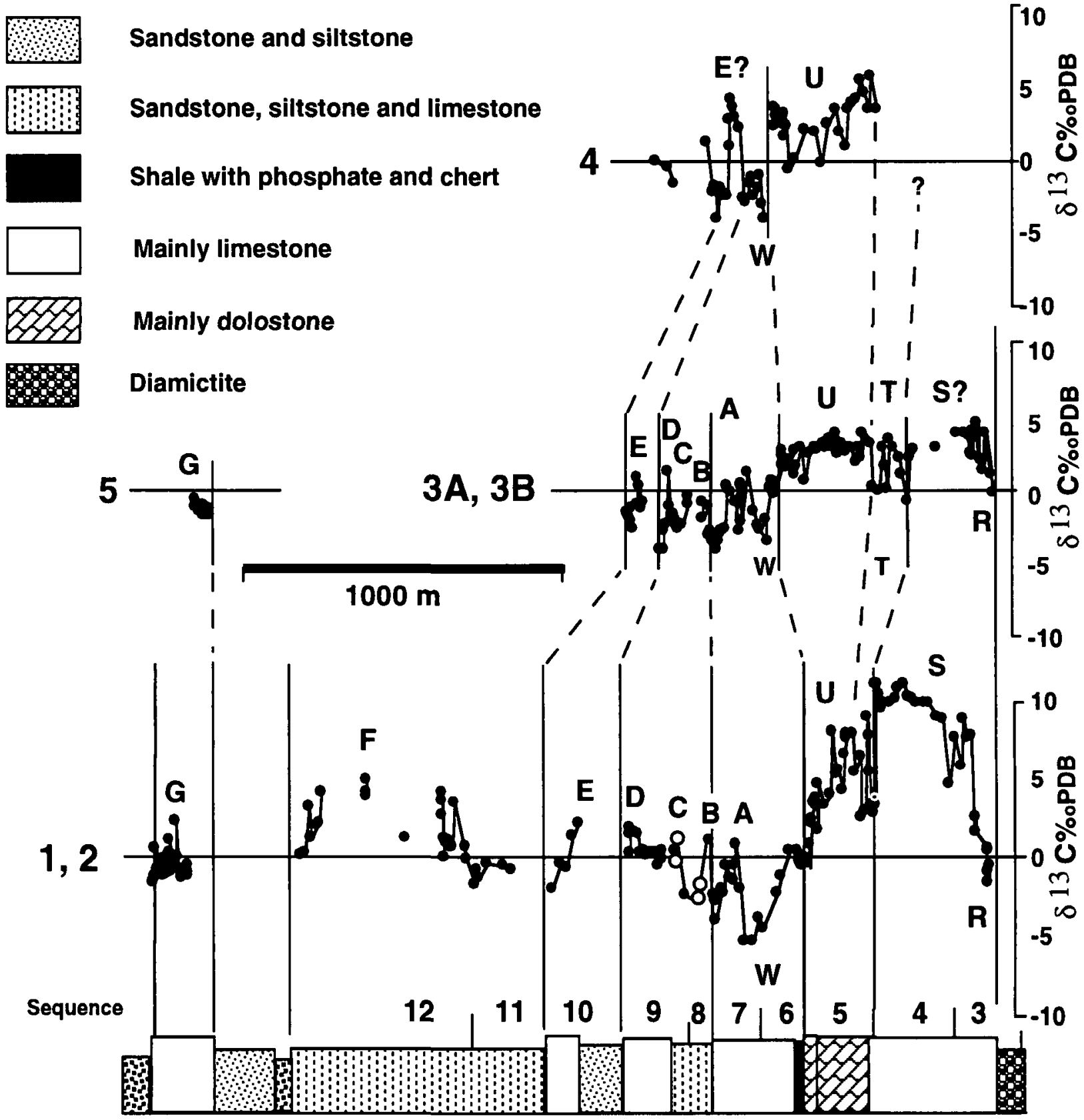

\begin{tabular}{|c|c|c|c|c|}
\hline Khayrkhan & Salaany Gol & Bayan Gol & \multicolumn{2}{|c|}{ Tsagaan Oloom } \\
\hline \multicolumn{2}{|c|}{ Lower Cambrian } & $?$ & Neoproterozoic \\
\hline
\end{tabular}

Figure 11. Comparison and correlation of carbon isotope curves obtained from the Neoproterozoic to early Cambrian of western Mongolia, calibrated by the boundaries of sequences 3 to 12 of Lindsay et al. (1996a, this issue). The columns show Section 1, Tsagaan Gol; Section 2, Salaany Gol; Section 3A, Bayan Gol northern block, plus Section 3B, Bayan Gol southern block; Section 4, KhevteTsakhir-Nuruu; Section 5, Zuune Arts. 'Suspect' carbon isotopic values (with $\delta^{13} \mathrm{C}>-5 \%$, $\delta^{18} \mathrm{O}>-15 \%$ or ferroan carbonate phases in the matrix) are shown as open circles. As can be seen, the filtering out of such values would have little impact on the curves. The suggested correlation of carbon isotopic features ' $R$ ' to ' $W$ ' and ' $A$ ' to ' $G$ ' indicates considerable contrasts in depositional rate between the sections. 
and KTN is not matched at Tsagaan Gol. Again this may imply that the upper part of the Boxonia grumulosa bed is missing at Tsagaan Gol.

Sequence 6 is marked by the distinctive negative anomaly of feature ' $W$ ' at each section, followed by the multiple peaks of carbon isotopic feature ' $A$ ' in sequence 7. The latter feature is seen at Bayan Gol and Tsagaan Gol but is not clearly defined at KTN. The top of sequence 7 is marked by sharply falling values.

The base of the Bayan Gol Formation (sequence 8) has a minor excursion at both Tsagaan Gol and Bayan Gol (Fig. 11, feature 'B'). Sequence 9 contains two peaks at both localities (features ' $C$ ', ' $D$ ') of which the latter reaches values of up to $2.0 \%$. At Bayan Gol, the uppermost carbonates in this sequence show a negative trend which is not seen at Salaany Gol, suggesting that nondeposition or erosion has cut out this portion of the profile.

Correlation of the Bayan Gol Formation at KTN is hindered by the lack of marker beds. Negative anomaly ' $W$ ' is here followed by values up to $4.3 \%$, which cannot be matched in sections to the west (Fig. 11). The succeeding, negative interval contains fossil assemblages at the base that elsewhere are not found below sequence 9 , followed by others typical of sequence 10 . This can best be explained if the positive excursion at KTN correlates with feature ' $E$ ', of which only the upper part is seen in sequence 10 at Salaany Gol and Bayan Gol (Fig. 11).

Slightly negative values are found above feature ' $E$ ' in sequence 11, both at Salaany Gol and at a correlative horizon at KTN. The carbon isotopic character of sequence 12 in the upper part of the Bayan Gol Formation is so far known only from data at Salaany Gol. Here, the great increase in thickness of clastic units, coupled with the relatively stable faunal character (Fig. 6a, b), suggest that the rate of sediment accumulation was increasing. This is also suggested by carbon isotopic feature ' $\mathrm{F}$ ', in which positive values above $3 \%$ (maximum $5.1 \%$ ) are spread through some $450 \mathrm{~m}$ of strata. A major break at the top of the Bayan Gol Formation is suggested by a weathered horizon followed by conglomerates. The Salaany Gol Formation at both Zuune Arts and Salaany Gol has yielded mainly negative $\delta^{13} \mathrm{C}$ values (feature ' $\mathrm{G}$ ').

Figures 12 and 13 show a composite carbon isotopic curve based upon the Tsagaan Gol-Salaany Gol section, to which extra data from Bayan Gol and Zuune Arts have been added. The suggested position of KTN feature ' $E$ '? is also shown.

\section{6.b. Strontium chemostratigraphy}

Previous studies have shown that the lowest ${ }^{87} \mathrm{Sr} /{ }^{86} \mathrm{Sr}$ ratios for a given time interval typically provide the best indication of coeval sea-water values (e.g. Derry et al. 1994; Smith et al. 1994; Nicholas, 1996) although this is not always the case (see Gao \& Land, 1991). Our 'leastaltered' samples from Mongolia follow this general rule of thumb quite well. In Figures 12 and 13, we put forward a suggested curve for ${ }^{87} \mathrm{Sr} /{ }^{86} \mathrm{Sr}$ in Neoproterozoic-early Cambrian sea-water.

The low ${ }^{87} \mathrm{Sr} /{ }^{86} \mathrm{Sr}$ ratio $(0.7057)$ of Riphean carbonates from Kantayshir must lie at some point below the base of the lower Maikhan Uul diamictite (see Section 5.a.3). If this value represents coeval sea-water (which appears possible from trace element and lithofacies data), this would indicate a pre-Sturtian stratigraphic age, that is, $>710 \mathrm{Ma}$ (see, e.g. Asmerom et al. 1991). In Figures 12 and 13 , the ${ }^{87} \mathrm{Sr} /{ }^{86} \mathrm{Sr}$ values obtained from carbonates above the upper diamictite are plotted against the composite carbon isotopic scale. The linear rise in values from 0.7067 to 0.7072 in sequence 3 coincides with the major rise in $\delta^{13} \mathrm{C}$ from -1.9 to $+7.3 \%$. 'Suspect' ${ }^{87} \mathrm{Sr} /{ }^{86} \mathrm{Sr}$ values in sequence 4 are not much higher (0.7073), while one 'suspect' sample from the base of sequence of 5 yields 0.7072 . There is little control yet over whether these latter values accurately record coeval sea-water, so they must be considered as maximum values for this time.

A steep rise in ${ }^{87} \mathrm{Sr} /{ }^{86} \mathrm{Sr}$ values takes place through sequence 5 , from 0.7072 in dolomites at the base, through 0.7077 in dolomites in the middle, to 0.7079 in a 'leastaltered' limestone near the top. Similar 'suspect' values (0.7079-0.7081) are also found in dolomites from just below the Boxonia grumulosa unit at KTN and continue to its top. Unfortunately, there is little control over whether or not such dolomites provide reliable ${ }^{87} \mathrm{Sr} /{ }^{86} \mathrm{Sr}$ ratios, but there are precedents for believing that dolomite samples can retain values close to those of original seawater (e.g. Burns \& Matter, 1993; Nicholas, 1996).

The shift towards 0.7084 in sequences 5 and 6 (at Bayan Gol and Tsagaan Gol) takes place through an interval of rapidly declining $\delta^{13} \mathrm{C}$ values and is punctuated by an abrupt drowning of the carbonate platform and the appearance of the Anabarites trisulcatus fauna. Ratios of 0.7084-0.7085 are maintained through the negative carbon isotope anomaly of feature ' $W$ ' and positive feature 'A' (sequence 7, Bayan Gol and KTN).

The change towards clastic facies in the Bayan Gol Formation is not accompanied by an appreciable change in ${ }^{87} \mathrm{Sr} /{ }^{86} \mathrm{Sr}$ ratios. Sequences 8 and 9 in the Bayan $\mathrm{Gol}$ Formation yield 'least-altered' values of 0.7084 (at Tsagaan Gol) rising to 0.7085 (at Salaany Gol). Similar values are maintained through sequence 10 (at Bayan Gol and Salaany Gol Ridge). It therefore appears that ${ }^{87} \mathrm{Sr} /{ }^{86} \mathrm{Sr}$ ratios remained relatively stable throughout the lower $800 \mathrm{~m}$ or so of the Bayan Gol Formation. 'Leastaltered' values in the upper part of the Formation at Salaany Gol Ridge (at the levels of sequences 11 and 12) show a drop to 0.7083 . A comparable but 'suspect' value of 0.70835 has also been obtained from just below calcimicrobial bioherms at Tayshir (sample Tayshir 1). Both results suggest that a slight decline in ${ }^{87} \mathrm{Sr} /{ }^{86} \mathrm{Sr}$ took place through the middle to upper part of the Bayan Gol Formation.

An erosional break lies beneath the Salaany Gol Formation, of which the lower part reveals a further drop 
in 'least-altered' values to 0.7082 (at Zuune Arts). A low but 'suspect' value of 0.7081 has also been obtained from correlative archaeocyath-bearing carbonates (sample A1) caught up in the ophiolite complex south of the town of Govi-Altay, described by Dorjnamjaa et al. (1993). The upper part of the Salaany Gol Formation shows little change, with 'suspect' values of $0.7081-0.7082$ (Salaany Gol). The consistency of these relatively low values from three different locations implies that the drop in ${ }^{87} \mathrm{Sr} /{ }^{86} \mathrm{Sr}$ was real. A further major erosional break is then followed by a slight rise to 'suspect' values of 0.7083 in the basal Kayrkhan Formation. It is possible, however, that components measured in these samples were reworked from the underlying Salaany Gol Formation.

\section{Global correlation}

\section{7.a. Neoproterozoic carbon isotope stratigraphy}

As discussed above, carbonates of the Tsagaan Oloom Formation lie above the double diamictite of the Maikhan Uul Member, which in turn rests on volcanic rocks of the Dzabkhan Formation, dated between 777 and 732 Ma BP. The diamictites could, however, belong to either the Sturtian or Varangerian glaciations, or both glacial phases could be present. Unfortunately, the microphytolites and Boxonia grumulosa in overlying carbonates may be of limited use for biostratigraphic correlation, although they have mainly been taken to indicate a Vendian age in the past (e.g. Dorjnamjaa \& Bat-Ireedui, 1991).

Chemostratigraphic comparisons between post-Sturtian and post-Varangerian carbonates are not straightforward. Relatively few sections have been characterized so far, and hiatuses are difficult to constrain without fossils, so that the following scheme (e.g. Kaufman \& Knoll, 1995) needs to be tested. (1) Carbonates thought to lie in the immediately post-Sturtian interval have negative $\delta^{13} \mathrm{C}$

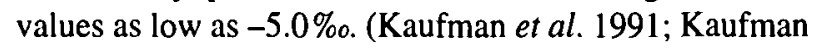
\& Knoll, 1995). (2) Carbonates through the rest of the post-Sturtian interval have values ranging from -2.5 to extremely positive values of +12.0 (Smith et al. 1994) or even +16.0 (Iyer et al. 1995), with the highest values in the upper part (Kaufman \& Knoll, 1995). Indeed, Smith et al. (1994) argue that values as high as +10 and above are confined to the post-Sturtian, pre-Varanger interval. However, high, perhaps untypical or lacustrine, $\delta^{13} \mathrm{C}$ values have been reported from the post-Varanger of Svalbard and Greenland (Knoll et al. 1986; Fairchild \& Spiro, 1987). (3) The Varangerian interval shows a trend towards negative values of -3.0 to -5.0 (Derry, Kaufman \& Jacobsen, 1992; Kaufman, Jacobsen \& Knoll, 1993; Narbonne, Kaufman \& Knoll, 1994; see Kaufman \& Knoll, 1995). (4) Post-Varangerian (Ediacarian) carbonates have values between -5.5 and +7.0 (Lambert $e$ al . 1987; Smith et al. 1994; Kaufman \& Knoll, 1995). (5) Late Ediacarian carbonates appear to have lower values, in the region of 2.0 to 1.0 , trending towards negative values close to the Precambrian-Cambrian boundary (Kaufman \& Knoll, 1995).

Our Precambrian carbon isotopic data admits of at least two possible age interpretations: entirely Ediacarian, or post-Sturtian plus Ediacarian. In the first interpretation, the low $\delta^{13} \mathrm{C}$ values of feature ' $R$ ' obtained from just above the Maikhan Uul diamictite (Figs 11,12) may be compared with values from above other diamictites of presumed Varangerian age around the world. This requires, however, that the heavy values of feature ' $S$ ' be regarded as anomalously high, related to localized conditions of evaporation (cf. Fairchild \& Spiro, 1987; Iyer et al. 1995), high productivity or carbon burial. Bituminous limestones deposited during this interval show no clear evidence for strong evaporation, although they could have been laid down in stratified waters with raised rates of carbon burial.

In the second interpretation, the very positive $\delta^{13} \mathrm{C}$ values of feature ' $S$ ' would be regarded as typical of the post-Sturtian interval. The abrupt shift towards negative values just above feature ' $S$ ' notably accompanies other indications of a gap in the record. It is possible, therefore, that the level of the Varangerian glaciation lies here, beneath feature ' $T$ '. The $\delta^{13} \mathrm{C}$ values of feature ' $U$ ' (see, e.g. Figs 11,12 ) would then compare well with positive values of up to $+7 \%$ reported from Ediacarian strata elsewhere. For further reasons given below, this is our preferred interpretation.

\section{7.b. Neoproterozoic strontium isotope stratigraphy}

Figure 12 shows the emerging framework for ${ }^{87} \mathrm{Sr} /{ }^{86} \mathrm{Sr}$ stratigraphy through the Neoproterozoic, which can be summarized as follows. (1) Least-altered post-Sturtian values lie between 0.7062 and 0.7072 (Derry, Kaufman \& Jacobsen, 1992; Smith et al. 1994). (2) Varangerian to immediately post-Varangerian values range between 0.7068 and 0.7073 (Derry, Kaufman \& Jacobsen, 1992; Narbonne, Kaufman \& Knoll, 1994). Least-altered samples suggest that sea-water ${ }^{87} \mathrm{Sr} /{ }^{86} \mathrm{Sr}$ ratios were close to 0.7066 before the earlier of the two Varanger phases of glaciation and reached a maximum of 0.7070 around the later phase (Derry et al. 1989). (3) Later post-Varangerian (Ediacarian) values rise to between 0.7080 and 0.7085 (Narbonne, Kaufman \& Knoll, 1994; Smith et al. 1994). The rise from 0.7066 to 0.7080 is poorly constrained at present, owing to the lack of suitable carbonate rocks above the diamictite (e.g. Derry, Kaufman \& Jacobsen, 1992; Kaufman, Jacobsen \& Knoll, 1993; Narbonne, Kaufman \& Knoll, 1994). A major problem concerns the comparable range in values found in post-Sturtian, Varangerian and immediately post-Varangerian carbonates (e.g. Derry et al. 1989; Derry, Kaufman \& Jacobsen, 1992; Kaufman, Jacobsen \& Knoll, 1993; Narbonne, Kaufman \& Knoll, 1994; Kaufman \& Knoll, 1995, fig. 6). This problem may be resolved by a combination of carbon and strontium isotope stratigraphy (Smith et al. 1994). 


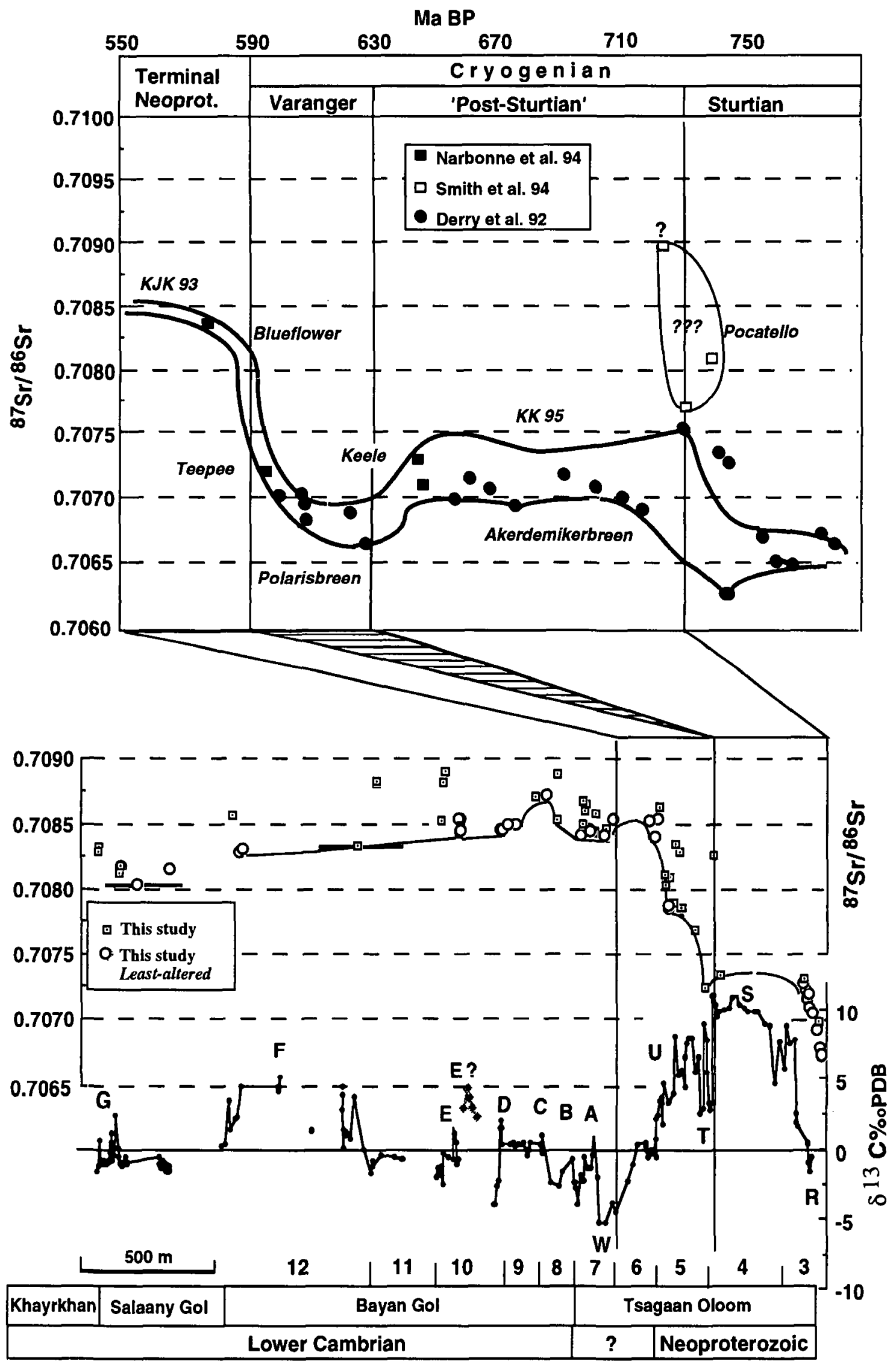

Figure 12. Above is shown the composite ${ }^{87} \mathrm{Sr} /{ }^{86} \mathrm{Sr}$ curve for the later part of the Neoproterozic, compiled from the data of Derry, Kaufman \& Jacobsen (1992), Narbonne, Kaufman \& Knoll (1994) and Smith et al. (1994), and references cited therein. 'KJK 93' shows the least-altered curve suggested by Kaufman, Jacobsen \& Knoll (1993). 'KK 95' shows the least-altered curve suggested by Kaufman \& Knoll (1995). In the lower figure, the ${ }^{87} \mathrm{Sr} /{ }^{86} \mathrm{Sr}$ data from southwest Mongolia (described in the text) is placed above the 
Returning to the Mongolian data, the very high $\delta^{13} \mathrm{C}$ values in sequences 3 and 4 , discussed in Section 7.a, suggested a post-Sturtian and pre-Varangerian age. The form of the ${ }^{87} \mathrm{Sr} /{ }^{86} \mathrm{Sr}$ curve is also consistent with this: a sharp rise (0.7068 to 0.7073 ) above the upper diamictite, followed by a plateau (Fig. 12; cf. Derry, Kaufman \& Jacobsen, 1992; Narbonne, Kaufman \& Knoll, 1994; Smith et al. 1994; Kaufman \& Knoll, 1995). Correlation is suggested, in part, with carbonates of the Shezal Formation, above the Rapitan glaciation and below the Icebrook glaciation. These rocks contain the first discoidal impressions of Ediacaria-type fauna (Narbonne, Kaufman \& Knoll, 1994). The sharp rise in ${ }^{87} \mathrm{Sr} /{ }^{86} \mathrm{Sr}$ values through sequences 5 and $6(0.7073$ to 0.7084$)$ coincides with carbon isotopic features ' $U$ ' to ' $W$ '. Both strontium and carbon isotopic data are consistent with a terminal Neoproterozoic 'Ediacarian' age for this part of the section (cf. Burns et al. 1994; Kaufman \& Knoll, 1995).

\section{7.c. Cambrian biostratigraphy vs. carbon chemostratigraphy}

Near the Precambrian-Cambrian boundary, it becomes possible to integrate carbon and strontium isotopic stratigraphy with data on small skeletal fossils. Correlation using small skeletal fossils is, however, hampered by several problems: they are long ranging, and their first first appearance datum points (FADs) are highly sporadic because of strong environmental and taphonomic controls (Brasier, 1990). Even so, similar 'homotaxial' successions of FADs can be seen across much of Asia (Missarzhevsky, 1982; Brasier, 1989). Such correlations can be tested objectively by means of computer-generated cross-plots of FADs between two sections (cf. 'Shaw diagrams').

In Figure 14 we illustrate cross-plots between our revised and unweighted data set on Mongolian FADs and those from published sections in Siberia and Iran. The wide spread of data shows the considerable freedom in correlating points between sections. We have attempted to overcome this problem by computing a 'best-fit line of correlation' from the data matrix (using computer-generated polynomial equations). Although this line provides some guidance to correlation, it could be misleading where there are major disparities in the preservation potential between two sections over a given time interval (e.g. Lindsay et al. 1996a, this issue). In this respect, we note the vastly greater thickness of putative NemakitDaldynian to mid-Tommotian strata in southwest
Mongolia (c. $1630 \mathrm{~m}$ of boundary strata, cf. c. $120 \mathrm{~m}$ in eastern Siberia), together with better lithofacies for preservation (largely limestones, cf. dolomites in eastern Siberia), and more numerous levels with SSF assemblages ( $c .24$, compared with $c .16$ in Iran, $c .11$ in eastern Siberia, c. 9 in the Olenek and c. 8 in Preanabar; e.g. Hamdi, 1989; Khomentovsky \& Karlova, 1993; Knoll et al. 1995b).

To test the comparative preservation potential of southwest Mongolian and Siberian sections we have plotted generic diversity against stratigraphic height (Fig. 15). Generic diversity was chosen to reduce the noise from taxonomic splitting; each taxon is assumed to range upwards without extinction. Abrupt increases in taxonomic diversity can be seen at the level of the 'Tommotian fauna' across eastern and northern Siberia. This increase lies close to the erosional break at the base of the Pestrotsvet Formation in eastern Siberia, which has been traced into northern Siberia (Khomentovsky \& Karlova, 1993). In southwest Mongolia, no such abrupt break is seen and the diversity increase appears linear.

The abrupt increase in taxonomic diversity seen at the base of the 'Tommotian fauna' in Siberian sections may not be evolutionary, therefore, but a product of an incomplete fossil record. Extensive dolomitization, with only sparse phosphatic intervals appears to have reduced the diversity of the 'Nemakit-Daldynian fauna'. The ensuing interval of erosion, non-deposition and condensation has then brought about an abrupt appearance of the 'Tommotian fauna'. Hence, it can be argued that the fossil record of invertebrate diversification in southwest Mongolia is more complete over this interval than in Siberia. Below, we test this hypothesis against the carbon and strontium isotope data.

\section{7.d. Cambrian carbon isotope stratigraphy}

Carbon isotope stratigraphy for the PrecambrianCambrian boundary has been described in numerous papers (e.g. references in Brasier et al. 1990; Ripperdan, 1994; Kaufman \& Knoll, 1995) and can be summarized as follows. (1) A major negative anomaly reaches values that are often lower (e.g. $-4.6 \%$, eastern Siberia) than seen at any time during the preceding Ediacarian or following Cambrian. (2) Carbon isotopic values climb again through the Nemakit-Daldynian Stage (the preTommotian rise or PTR of Ripperdan, 1994). (3) The first, positive, cycle $\mathrm{Z}$ is punctuated by the earliest skeletal fossil assemblages in eastern Siberia (Brasier, Khomentovsky \& Corfield, 1993). (4) Maximal values of

composite carbon isotopic curve, lithostratigraphy and sequence stratigraphy. Open circles mark 'least-altered' ${ }^{87} \mathrm{Sr} /{ }^{86} \mathrm{Sr}$ ratios (see Fig. 4 and Table 1). Squares mark 'suspect', often higher, values, in which less confidence is placed. The lower bounding line to the ${ }^{87} \mathrm{Sr} /{ }^{86} \mathrm{Sr}$ data is taken to define a ${ }^{87} \mathrm{Sr} /{ }^{86} \mathrm{Sr}$ curve based largely on least-altered samples. Comparison with the global data suggests that sequences 3 and 4 of the Tsagaan Oloom Formation spans the post-Sturtian interval, and that sequences 5 and 6 span the Terminal Neoproterozic. If so, then the Varanger glaciation lies within the break between sequences 4 and 5 . Other possible interpretations are discussed in the text. 


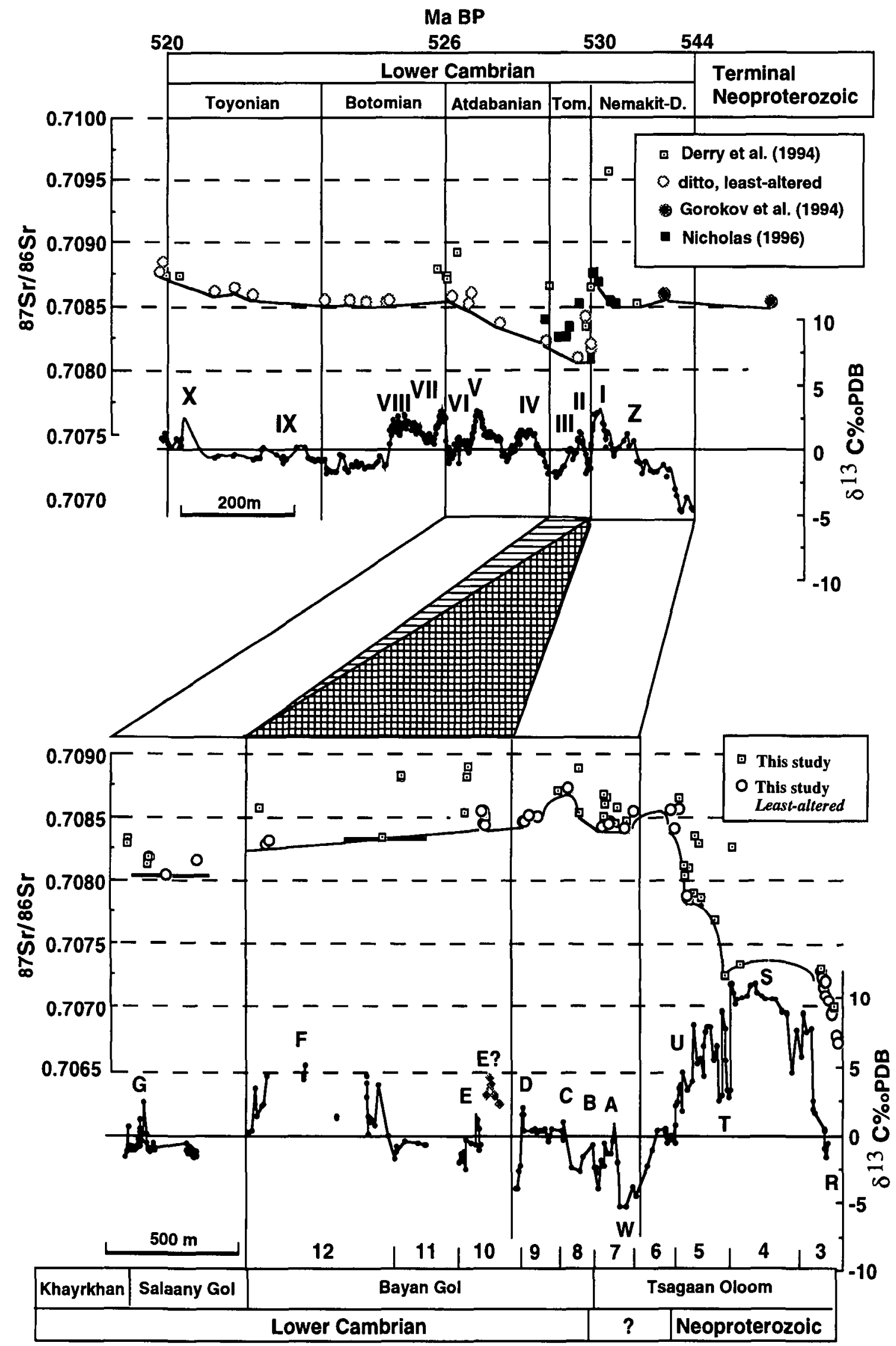

Figure 13. Above is shown the composite ${ }^{87} \mathrm{Sr} /{ }^{86} \mathrm{Sr}$ curve for the Lower Cambrian of Siberia, compiled from the data of Derry $e t$ al. (1994), Gorokov et al. (1995) and Nicholas (1996), alongside the carbon isotope record of Siberia (compiled from data in Brasier $e t$ al. 1994b), and provisional absolute ages (from data in Bowring et al. 1993). The abrupt shifts in ${ }^{87} \mathrm{Sr} /{ }^{86} \mathrm{Sr}$ and $\delta^{13} \mathrm{C}$ values at the base of the Tommotian are consistent with other evidence for a major break at this level in eastern Siberia (see text). In the lower figure, the ${ }^{87} \mathrm{Sr} /{ }^{86} \mathrm{Sr}$ data from southwest Mongolia (described in the text) is placed above the composite carbon isotopic curve, lithostratigraphy 
cycle I (c. $+3.3 \%$, eastern Siberia) occur not far beneath the Tommotian and have been correlated globally. (5) Values as high as $5.4 \%$ are found close to the NemakitDaldynian/Tommotian boundary in Iran and in the Preanabar region of northwest Siberia, where they have been correlated with cycle I in eastern Siberia (Brasier $e t$ al. 1990; Pokrovsky \& Missarzhevsky, 1993). Knoll et al. (1995b) and Kaufman et al. (1996) argue, however, that these high values belong to a cycle I' which is missing from eastern Siberia in the hiatus between the two stages. (6) A further nine isotopic cycles occur between the base of the Tommotian and the base of the middle Cambrian in eastern Siberia, with values oscillating between -2.0 and +3.2 (Magaritz, Holser \& Kirschvink, 1986; Magaritz, 1989; Kirschvink et al. 1991; Magaritz et al. 1991; Brasier et al. 1994a,b).

Figure 14a to $\mathrm{d}$ compares the carbon isotope stratigraphy from Mongolia with those from eastern Siberia (Magaritz, Holser \& Kirschvink, 1986; Brasier, Khomentovsky \& Corfield, 1993), Kotuikan in Preanabar, northwest Siberia (Pokrovsky \& Missarshevsky, 1993), the Olenek uplift, northern Siberia (Knoll et al. 1995a; Pelechaty et al., in press) and northern Iran (Brasier $e t$ al. 1990) alongside the cross-plots of biostratigraphic data (see Section 7.c). Cross-correlation is anchored by negative anomaly ' $W$ ', which lies at the level of the first skeletal faunas of the Anabarites trisulcatus Zone (in Preanabar), or just above (Mongolia, Olenek) or not far below (eastern Siberia). In each region, there appears to be a double negative peak, and at Kotuikan, the base of the Nemakit-Daldynian (= Manykayan) Stage lies between the peaks, at the base of the Manykay Formation (Pokrovsky \& Missarzhevsky, 1993).

Figure 14a shows that isotopic features ' $D$ ' and ' $E$ ' in Mongolia compare reasonably well in position and magnitude with cycle I of eastern Siberia. There are, however, several mismatches. Firstly, the 'Tommotian fauna' is spread through isotopic features ' $C$ ' to ' $F$ '. The base of the Tommotian could therefore lie as low as the base of feature ' $\mathrm{C}$ ' or as high as the top of feature ' $\mathrm{F}$ '. Secondly, the very positive values of features ' $E$ ' and ' $F$ ' cannot be matched in eastern Siberia (at any point in the lower Cambrian).

There are fewer points for comparison with the Olenek uplift (Fig. 14b). The Kessyuse Formation has values up to $4.0 \%$ (Knoll et al. 1995a), at a position that compares with features ' $D$ ' to ' $E$ ' in Mongolia. It is important to note that these peak values in the Kessyuse Formation lie at a level which, in eastern Siberia would be regarded as 'Nemakit-Daldynian' on the grounds of chemostratigraphy (cycle I) and its position beneath a major sequence boundary. In the Olenek, however, the faunas of presumed cycle I contain a basal Tommotian fauna (Khomentovsky \& Karlova, 1993). Event stratigraphy therefore suggests that the Tommotian fauna is diachronous across Siberia.

The carbon isotope and SSF stratigraphies of Mongolia and Preanabar are more easily matched (Fig. 14c), notably features ' $F$ ' and cycle I' at the top of each section. As mentioned above, cycle I' may be the same as cycle I or it may be missing from eastern Siberia, owing to the hiatus beneath the Tommotian (Kaufman et al. 1996). The latter interpretation could explain why the first appearance of 'Tommotian faunas' is stretched out in both Preanabar and Mongolia, through the interval with features ' $E$ ' to ' $F$ '. Such an interpretation is bound to be controversial, however, owing to the presence of supposed middle Tommotian markers at the level of cycle l', with Atdabanian fossils not far above (Dr A. Zhuravlev, pers. comm., 1995). Our carbon isotopic data may therefore be taken to indicate either that there is a major excursion in the middle Tommotian that is as yet undetected in eastern Siberia, or that there is a major hiatus at the base of the Tommotian Stage in eastern Siberia.

Correlation with the Elburz Mountains of Iran (Fig. 14d) is hampered by thick clastic intervals in the upper part of the Iranian section. The positive excursion at the base of the Upper Shale was originally compared with cycle $I$ in eastern Siberia and the Dahai maximum in southern China (Brasier et al. 1990). More recently, Knoll et al. (1995b) and Kaufman et al. (1996) have compared this excursion with the 'heavier' cycle $I^{\prime}$ in Preanabar. Figure $14 \mathrm{~d}$ suggests that such a correlation has little biostratigraphic support. Instead, we make correlations with features ' $D$ ' and ' $E$ ' which are more consistent with fossil data and isotopic amplitude. Feature ' $F$ ' would therefore appear to be unsampled or absent in Iran.

At the top of the Mongolian section, mainly negative values of the Salaany Gol Formation provide some constraints on correlation. Five such intervals are present in eastern Siberia (Figs 11, 12), of which those in the midAtdabanian and upper Atdabanian are consistent with archaeocyath data in the Salaany Gol Formation. There is no chemostratigraphic support for suggestions that this formation ranges into the lower Botomian (e.g. Voronin et al. 1982), which is characterized in Siberia by markedly positive values (Brasier et al. 1994a).

\section{7.e. Cambrian strontium isotope stratigraphy}

The strontium isotope stratigraphy for the early Cambrian (Figure 13) has been described from eastern Siberia by Derry et al. (1994), with additional data in Gorokhov

and sequence stratigraphy (as in Fig. 12). Comparison with the Siberian data suggests that sequences 7 to 9 of the Bayan Gol Formation span the Nemakit-Daldynian interval of eastern Siberia. Sequences 10 to 12 , with carbon isotopic features ' $E$ ' and ' $F$ ', may span the Tommotian (horizontal hatching) or span the hiatus at the base of the Tommotian in eastern Siberia (cross-hatching). Either way, this interval may be correlated with the Medvezhaya Formation of Preanabar, northern Siberia (cf. Knoll et al. 1995b, Kaufman et al. 1996). Other possible interpretations are discussed in the text. 

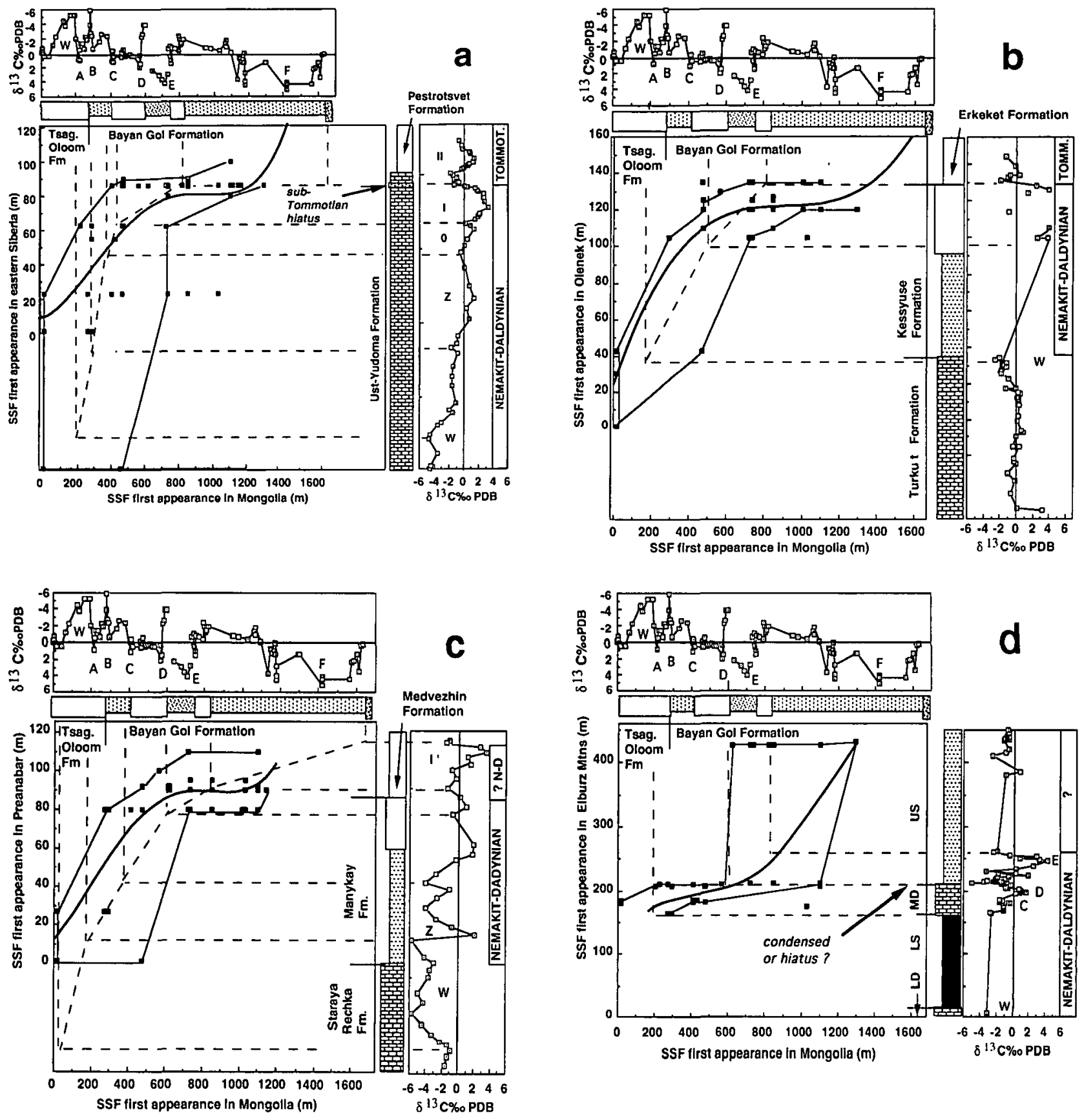

Figure 14. The so-called 'explosive phase' of the Cambrian radiation is illustrated by these four integrated biostratigraphychemostratigraphy cross-plots. For each of four sections, data on the stratigraphic height (in metres) of SSF first appearances is used to generate a matrix with similar data from southwest Mongolia. Points of correlation lie largely within an envelope of probable biostratigraphic correlation (two thin lines). The curving median line in each cross-plot may be taken as a 'best-fit line of correlation', and was produced using computer-generated polynomial equations. Negative carbon isotope anomaly ' $W$ ' is used as an anchor point. Dotted lines of suggested correlation between this and later negative isotopic features have been drawn in such a way as to lie reasonably close to the 'best-fit line'. The matrices thus formed between Mongolia and (a) eastern. Siberia, (b) Preanabar, northern Siberia, and (c) Olenek in northern Siberia suggest that these Siberian sections are affected by condensation or missing strata in the mid to upper part of carbon cycle I. A comparable 'break' in the fossil record appears to be indicated just above correlated feature ' $D$ ' in Iran (d). These inferred breaks are followed by 'explosive phases' in the respective diversity curves (Fig. 15). Isotopic data are taken from Mongolia (herein); eastern Siberia: Brasier, Khomentovsky \& Corfield (1993); Brasier et al. (1994b); Olenek: Knoll et al. (1995a); Preanabar: Pokrovsky \& Missarzhevsky (1993); Knoll et al. (1995b); Iran: Brasier et al. (1990). SSF data from Mongolia (sources in the text); Siberia: Khomentovsky \& Karlova (1993); Knoll et al. (1995b); Iran: Hamdi (1989). LD = Lower Dolomite; LS = Lower Shale; MD = Middle Dolomite; US = Upper Shale. 
et al. (1995) and Nicholas (1996). The main trends are as follows. (1) Dolostones of the lower Nemakit-Daldynian stage (above anomaly ' $W$ ') yield least-altered ${ }^{87} \mathrm{Sr} /{ }^{86} \mathrm{Sr}$ ratios of around 0.7085 . (2) Carbon cycle $I$ of the Nemakit-Daldynian yields values of $c$. $0.7086-0.7087$ or higher. (3) Limestones of the basal Tommotian show a sharp drop down to 0.7081 , which appears to be maintained through to the middle Tommotian. (4) Values rise to 0.7083 in the basal Atdabanian and reach 0.7085 near the top of the Atdabanian Stage. (5) Botomian values also lie at around 0.7085 . (6) Least-altered values rise to 0.7087 at the base of the Amgan Stage (middle Cambrian).

The strontium isotope data from Mongolia (Fig. 13) provide an intriguing picture. 'Least-altered' ratios of $0.7084-0.7085$ range through carbon isotope anomaly ' $W$ ' to feature ' $E$ ' and are consistent with a NemakitDaldynian age. A poorly characterized peak of values (0.7087), like that at the top of the Nemakit-Daldynian, occurs at the base of sequence 9 , followed by a downward shift towards Tommotian values of 0.7083 reached near the top of the Bayan Gol Formation. So long and gentle is this fall in ${ }^{87} \mathrm{Sr} /{ }^{86} \mathrm{Sr}$ values, in comparison with that seen in eastern Siberia, that one must seriously consider whether the Bayan Gol Formation includes strata either condensed or missing from the base of the type Tommotian. This explanation certainly has the power to explain some otherwise mystifying phenomena, such as the abrupt diversification in fauna at the base of the Tommotian in eastern Siberia (Fig. 15), the abrupt downward shift in ${ }^{87} \mathrm{Sr} /{ }^{86} \mathrm{Sr}$ ratios at the same level, and the absence of carbon isotopic features ' $E$ ' and ' $F$ ' (= cycle I' of Kaufman et al. 1996).

The ${ }^{87} \mathrm{Sr} /{ }^{86} \mathrm{Sr}$ values obtained from the Salaany Gol Formation provide yet further, surprising comparisons. Ratios of $0.7081-0.7082$ are below those reported from the upper Atdabanian of eastern Siberia but compare with values from the upper Tommotian to mid-Atdabanian. Furthermore, ratios of 0.7083 from the Khayrkhan Formation are appreciably lower than those from the type Botomian, although we cannot discount that the material sampled represents clasts reworked from below.

Strontium isotope stratigraphy would therefore seem to suggest that the Cambrian formations of Mongolia could be somewhat older than estimated from earlier biostratigraphic correlations. These previous correlations therefore deserve critical scrutiny on biostratigraphic grounds. Alternatives to this view are as follows. (1) The $\mathrm{Sr}$ isotopes in Siberia and Mongolia have been inadequately sampled to date. This appears unlikely given the concordance of results obtained from each area. (2) Diagenetic exchange effects have brought about isotopic resetting. Such effects are, however, largely overcome by the use of 'least-altered values' discussed above. (3) $\mathrm{Sr}$ isotopes in Mongolia have experienced a lag effect owing to poor exchange with sea-water. This would mean that the Mongolian sections were deposited in a basin cut off from the Sr reservoir of the ocean for most of the time in order to develop their own ${ }^{87} \mathrm{Sr}{ }^{86} \mathrm{Sr}$ signature. All the evidence of lithofacies and biofacies is, however, against such a restricted setting. (4) The $\mathrm{Sr}$ isotope ratio of seawater was not the same worldwide in Early Cambrian time. This would mean that the Mongolian samples (or the Siberian samples for that matter) would not be truly representative of sea-water as a whole. Such an inference goes against the basic assumption of strontium isotope stratigraphy, that the oceans are thoroughly mixed with respect to $\mathrm{Sr}$ at any one time.

\section{Conclusions}

The following conclusions may be drawn from this study.

(1) Limestones above the Maikhan Uul diamictites have negative $\delta^{13} \mathrm{C}$ values (negative anomaly ' $R$ ') and ${ }^{87} \mathrm{Sr} /{ }^{86} \mathrm{Sr}$ ratios like those found elsewhere above both the Sturtian and Varangerian glaciations. At higher levels in the Tsagaan Gol Formation, however, very positive $\delta^{13} \mathrm{C}$ values are reached $(<11.4 \%$; feature ' $\mathrm{S}$ ') and ${ }^{87} \mathrm{Sr} /{ }^{86} \mathrm{Sr}$ ratios outline a plateau at around 0.7073 . Both compare well with values known elsewhere from postSturtian/Rapitan carbonates. A sharp fall in $\delta^{13} \mathrm{C}$ (feature ' $\mathrm{T}$ ') and suspected drop in ${ }^{87} \mathrm{Sr} /{ }^{86} \mathrm{Sr}$ follows the sequence $4 / 5$ boundary, below which there is evidence for recrystallization and karstic solution. This break could well lie at the level of the Varangerian glaciation.

(2) Carbon isotopic values in the succeeding sequence 5 do not exceed $8.0 \%$ (feature ' $U$ ') and fall as the Boxonia grumulosa stromatolite unit is approached. Positive carbon isotopic values $(<8.0 \% 0)$ and ${ }^{87} \mathrm{Sr} /{ }^{86} \mathrm{Sr}$ ratios climbing towards 0.7085 , indicate a postVarangerian (Ediacarian) age.

(3) A major negative $\delta^{13} \mathrm{C}$ anomaly (feature ' $\mathrm{W}$ ') is found in the interval between the latest Neoproterozoic and the earliest Cambrian. This anomaly is unrelated to facies changes and lies up to $200 \mathrm{~m}$ above a sharp, diagenetically-influenced, fall in $\delta^{18} \mathrm{O}$. A similar negative anomaly is also known from this level in Siberia, Iran and northwest Canada (see, e.g. Brasier et al. 1990; Brasier et al. 1994a; Ripperdan, 1994; Kaufman \& Knoll, 1995). Its discovery in Mongolia confirms that anomaly ' $W$ ' is a synchronous geochemical marker, with important potential for global correlation. Least-altered ${ }^{87} \mathrm{Sr} /{ }^{86} \mathrm{Sr}$ values of $0.7084-0.7085$ occur in this interval.

Carbon isotope anomaly ' $W$ ' may be used to trace the diachronous appearance of the Anabarites trisulcatusProtohertzina fauna across the globe. In most regions so far studied, this assemblage appears within or above anomaly ' $W$ '. The earliest example of this assemblage in Mongolia, however, comes from levels below anomaly ' $W$ ', in the upper part of feature ' $U$ ', at a level comparable with the appearance of Cambrotubulus sp. in the Olenek uplift (Knoll et al. 1995a). At Tsagaan Gol, this level also contains the oldest known assemblage of hexactinellid sponge spicules.

(4) Multiple carbon isotopic peaks are found within the overlying lower Cambrian of the upper Tsagaan Oloom to 


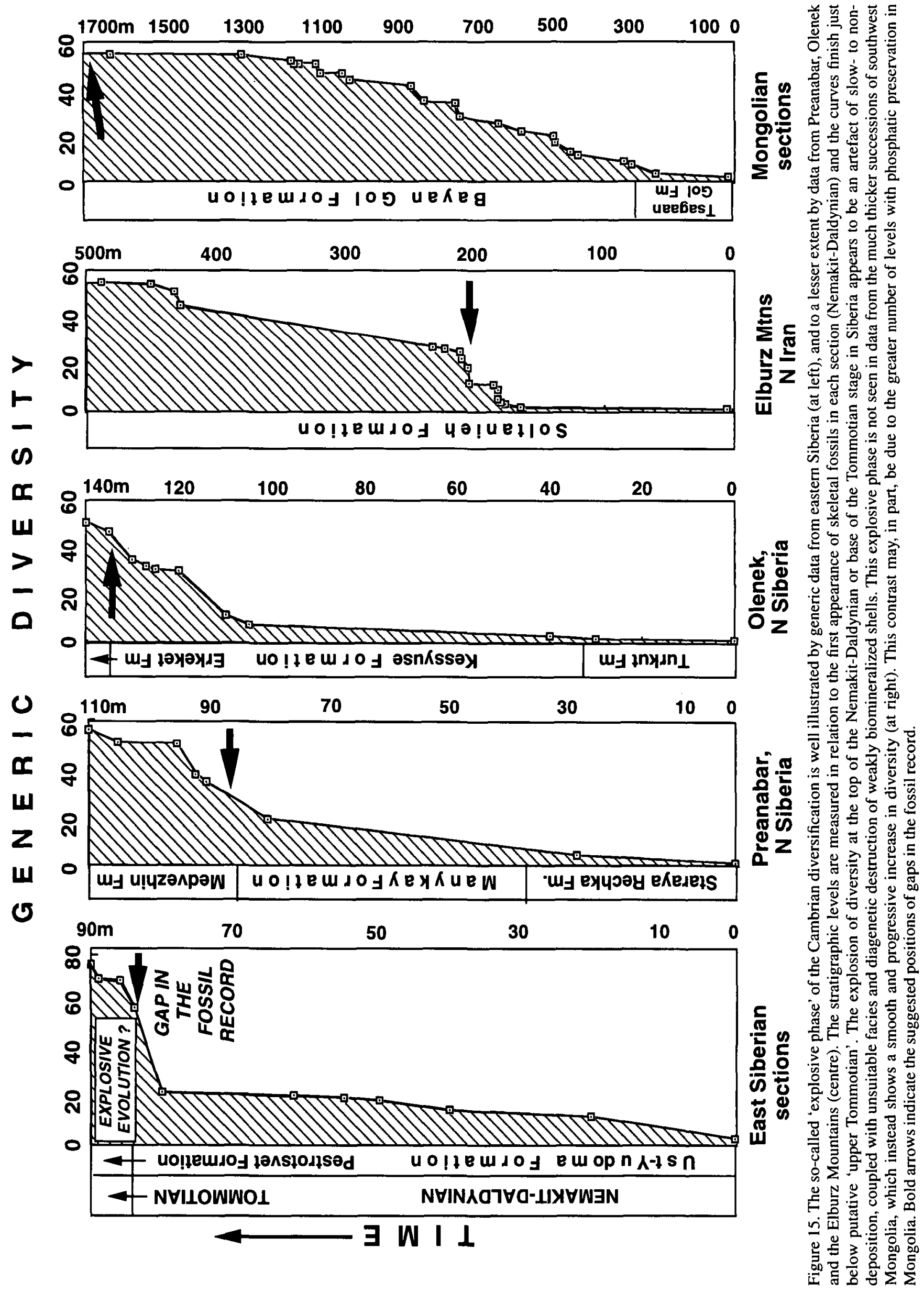


Bayan Gol formations (features ' $A$ ' to ' $F$ '). These peaks successively exceed $2 \%$ (feature ' $D$ '), $4 \%$ (feature ' $E$ '?) and $5 \%$ (feature ' $F$ '). Least-altered ${ }^{87} \mathrm{Sr} /{ }^{86} \mathrm{Sr}$ values of 0.7084-0.7085 are sustained through features ' $A$ ' to ' $B$ ', with a peak of 0.7087 close to feature ' $\mathrm{C}$ ', falling to 0.7083 in the region of feature ' $F$ '. Such carbon and strontium isotope values compare well with those from the Nemakit-Daldynian to earliest Tommotian of Siberia. Cross-plots of SSFs are consistent with a correlation between features ' $B$ ' to ' $D$ ' and carbon cycles $Z$ to $I$ in eastern Siberia.

An important contrast emerges, however, with the type Tommotian of Siberia, which lacks the heavy $\delta^{13} \mathrm{C}$ of feature ' $\mathrm{F}$ ' and yields much lower ${ }^{87} \mathrm{Sr} /{ }^{86} \mathrm{Sr}$ values of 0.7081 (cf. Derry et al. 1994; Nicholas, 1996). Chemostratigraphic data point to the possibility that the Bayan Gol Formation, with its rich succession of early skeletal fossils, could be entirely pre-Tommotian. This interpretation has the power to explain major contrasts in the rate of diversification of SSFs recorded from different sections. In eastern Siberia, the succession is thin, SSF horizons are comparatively few, and an important hiatus lies below the base of the Tommotian, which is followed by a leap in diversity. In southwest Mongolia, the succession is thick, reported SSF horizons are more numerous, and the SSF diversity climbs steadily through the section.

(5) Carbon isotopes are mainly negative in the unconformably overlying Salaany Gol Formation, which yields ${ }^{87} \mathrm{Sr} /{ }^{86} \mathrm{Sr}$ values of $0.7081-0.7082$ from several widely dispersed sections. This combination of values would admit a Tommotian to mid-Atdabanian age but not the late Atdabanian to Botomian age suggested by Voronin et al. (1982).

(6) Trace fossils, of a type only known from the Cambrian and above, first appear near the base of the Bayan Gol Formation (Goldring \& Jensen, 1996, this issue) at the level of carbon isotopic feature ' $B$ ', with ${ }^{87} \mathrm{Sr} /{ }^{86} \mathrm{Sr}$ ratios of 0.7084 . According to the data of Khomentovsky \& Gibsher (1996, this issue), this assemblage would correlate with the Purella antiqua Zone of the Nemakit-Daldynian Stage in Siberia, which lies in the upper part of carbon isotope cycle $\mathrm{Z}$ (Brasier, Khomentovsky \& Corfield, 1993). Cambrian ichnofossil assemblages with Phycodes pedum and Rusophycus cf. avalonensis lie higher in the Bayan Gol Formation (Goldring \& Jensen, 1996, this issue), bracketed by carbon isotopic features ' $D$ ' and ' $E$ ' and by ${ }^{87} \mathrm{Sr} /{ }^{86} \mathrm{Sr}$ values of 0.7085 .

Phycodes spp. is not yet known from anywhere below negative anomaly ' $W$ '. It appears a little above this anomaly in northwest Canada (Narbonne, Kaufman \& Knoll, 1994) and, perhaps, at a similar level in northern Siberia (Fedonkin, 1987; Bowring et al. 1993).

(7) Our Mongolian data have important evolutionary implications. Hitherto, it has been assumed that the Cambrian diversification of animals entered its 'explosive phase' at the beginning of the Tommotian (e.g. Rozanov, 1992) or during the later Nemakit-Daldynian (Knoll et al.
$1995 a$ ) in Siberia. The Mongolian evidence suggests that these two 'explosive phases' are actually artefacts of slow sediment accumulation rate, unsuitable facies and diagenesis, and that the true course of evolution was much smoother and more progressive, beginning as far back as the Ediacarian. The exact form of the curve must depend on assumptions about sediment accumulation rate and absolute dating.

Acknowledgements. We thank colleagues at the Palaeontological Institute (Moscow), Dorjnamjaa, Bat-Ireedui, Soelmaa and colleagues at the Geological Institute (Ulaan Baatar), plus Stefan Bengtson (Uppsala), V. V. Khomentovsky (Novosibirsk) and Rachel Wood (Cambridge) for field support. A. Yu. Rozanov (PIN, Moscow) and R. Barsbold (Ulaan Baatar) are thanked for help in arranging the expeditions. Julie Cartlidge, Roy Goodwin and Martin Whitehouse (Oxford) assisted with preparation of samples and mass spectrometry, and the late Andy Clark drafted the original figures. GS would like to thank R. Steiger, F. Oberli, F. Madsen, Frau Fonyo and M-T. Baer of the ETH Zürich and P. Stille and B. Kiefel of the CGS/CNRS Strasbourg for their technical supervision and expertise. The research of $E$. Zhegallo was supported by the Russian foundation for Fundamental Research, project no. RFFI 93-05-8503. Andrey Zhuravlev (PIN) and Andy Knoll (Harvard) are thanked for useful comments on the manuscript.

\section{References}

Allen, J. R. \& MATTHEws, R. K. 1982. Isotopic signatures associated with early meteoric diagenesis. Sedimentology 29, 797-817.

Amantov, V. A. 1963. The principal characteristic features of stratigraphy and environmental conditions for the formation of Cambrian deposits in the north-east of Mongolia. Materials on the Geology of the MPR. Gostopotekhizdat $1963,15-28$ (in Russian).

ASmerom, Y., Jacobsen, S. B., KNOll, A. H., Butterfield, N. J. \& SwETT, K. 1991. Sr isotope variations in Late Proterozoic seawater: Implications for crustal evolution. Geochimica et Cosmochimica Acta 55, 2883-94.

Astashkin, V., Pegel', T. V., Repina, L. N., Belyaeva, G. V., Esakova, N. V., Rozanov, A. Yu., Zhuravlev, A. Yu., OsadChaYA, D. V. \& PKHOMOV, N. N. 1995. The Cambrian System of th Foldbelts of Russia and Mongolia. International Union of Geological Sciences, Publication no. 32.

Baikova, V. S. \& Amelin, Yu. V. 1994. Sm-Nd age of Gashunnursky dyke complex (Mongolia). Doklady Academii Nauk Rossii 334, 343-5 (in Russian).

Bezzubetsev, V. V. 1963. On the Precambrian-Cambrian stratigraphy of the Dzabkhan River Basin. Materials on the Geology of MPR. Gostopotekhizdat 1963, 29-42 (in Russian).

Bowring, S. A., Grotzinger, J. P., Isachsen, C. E., KNoll, A. H., Pelechaty, S. \& Kolosov, P. 1993. Calibrating Cambrian evolution. Science 261, 1293-8.

Brand, U. \& Veizer, J. 1980. Chemical diagenesis of a multicomponent carbonate system - 1: Trace elements. Journal of Sedimentary Petrology 50, 1219-36.

Brasier, M. D. 1989. Palaeotethyan sections. In The Precambrian-Cambrian boundary (eds J. W. Cowie and M. D. Brasier), pp. 117-65. Oxford: Clarendon Oxford.

Brasier, M. D. 1990. Phosphogenic events and skeletal preservation across the Precambrian-Cambrian boundary 
interval. In Phosphorite Research and Development (eds A. G. Notholt and I. Jarvis), pp. 289-303. Geological Society, London, Special Publication no. 52.

BRASIER, M. D. 1992. Introduction. Background to the Cambrian explosion. Journal of the Geological Society, London 149, 585-7.

Brasier, M. D., ANDERSon, M. M. \& CORfIEld, R. M. 1992. Oxygen- and carbon-isotope stratigraphy of early Cambrian carbonates in Southeastern Newfoundland and England. Geological Magazine 129, 265-79.

Brasier, M. D., Corfield, R. M., Derry, L. A., Rozanov, A. Yu. \& Zhuravlev, A. Yu. $1994 a$. Multiple $\delta^{13} \mathrm{C}$ excursions spanning the Cambrian explosion to the Botomian crisis in Siberia. Geology 22, 455-8.

Brasier, M. D., CowIE, J. W. \& TAYloR, M. 1994. Decision on the Precambrian-Cambrian boundary stratotype. Episodes 17, 3-8.

Brasier, M. D., Khomentovsky, V. V. \& Corfield, R. M. 1993. Stable isotopic calibration of the earliest skeletal fossil assemblages in eastern Siberia (PrecambrianCambrian boundary). Terra Nova 5, 225-32.

Brasier, M. D., Magaritz, M., Corfield, R., Luo Huilin, Wu Xiche, Ouyang Lin, Jiang Zhiwen, Hamd, B., He Tinggul \& Fraser, A. G. 1990. The carbon- and oxygen-isotope record of the Precambrian-Cambrian boundary interval in China and Iran and their correlation. Geological Magazine 127, 319-32.

Brasier, M. D., Rozanov, A. Yu., Zhuravlev, A. Yu., CORFIELD, R. M. \& DERRY, L. A. 1994b. A carbon isotope reference scale for the Lower Cambrian succession in Siberia: Report of IGCP Project 303. Geological Magazine 131, 767-83.

BuRns, S. J., HAUdENSCHILd, U. \& MATTER, A. 1994. The strontium isotopic composition of carbonates from the late Precambrian (ca. 560-540 Ma) Hugf Group of Oman. Chemical Geology 111, 269-82.

Burns, S. J. \& MATTER, A. 1993. Carbon isotopic record of the latest Proterozoic from Oman. Eclogae Geologica Helvetiae 86, 595-607.

BuyaKayte, M. J. \& Kuz'michev, A. B. 1989. 718 million years: the $\mathrm{Rb}-\mathrm{Sr}$ erochron of the Arkoi Series of Eastern Sayan. Doklady Akademii Nauk SSSR, 150-4 (in Russian).

Coleman, R. G. 1990. Can international cooperation help reconstruct the Paleo-Asian ocean? Episodes 13(3), 184-5.

Derrr, L. A., Brasier, M. D., Corfield, R. M., Rozanov, A. Yu. \& Zhuravlev, A. Yu. 1994. Sr and C isotopes in Lower Cambrian carbonates from the Siberian craton: a palaeoenvironmental record during the "Cambrian excursion'. Earth and Planetary Science Letters 128, 671-81.

Derry, L. A., Kaufman, A. J. \& Jacobsen, S. B. 1992. Sedimentary cycling and environmental change in the Late Proterozoic: evidence from stable and radiogenic isotopes. Geochimica et Cosmochimica Acta 56, 1317-29.

Derry, L. A., Keto, L. S., Jacobsen, S. B., Knoll, A. H. \& SWETT, K. 1989. Sr isotopic variations in Upper Proterozoic carbonates from Svalbard and East Greenland. Geochimica et Cosmochimica Acta 53, 2331-9.

DorjnamuaA, D. \& Bat-Ireedui, Y. A. 1991. Dokembriy Mongolii. Akademia Nauk MPR, Geological Institute (in Russian).

DorjnamuaAa, D. \& Bat-Ireedui, Y. A., DashdavaA, Z. \& SoelmaA, D. 1993. Precambrian-Cambrian Geology of the Dzavkhan Zone. Unpublished excursion guidebook. Earth Sciences Department, Oxford, $36 \mathrm{pp}$.

Drozdova, N. A. 1980. Algae in Lower Cambrian mounds of western Mongolia. Trudy Sovmestnaya Sovetsko-
Mongol'skaya Paleontologicheskaya Ekspeditsiya, Moscow, 10, 1-140 (in Russian).

ENDONZHAMTS, ZH. \& LKHASUREN, B. 1988. Stratigraphy of the transitional beds between the Precambrian and Cambrian in the Zavkhan zone. Pozdniy Dokembriy i Ranniy Paleozoy Sibiri. Riphey $i$ Vend. Izdatelstvo Instituta Geologii i Geophiziki, Novosibirsk, pp. 150-62 (in Russian).

EsAKova, N. V. \& ZHEGALlo, E. A. 1996. Stratigrafaya i fauna nizhnego Kembriya Mongolii (Lower Cambrian stratigraphy and fauna of Mongolia). Sovmestnaya SovetskoMongol'skaya Paleontologicheskaya Ekspeditsiya, Moscow, 46, 208 pp. (in Russian).

FAIRCHILD, I. J. \& SPIRO, B. 1987. Petrological and isotopic implications of some contrasting Late Precambrian carbonates, E. Spitsbergen. Sedimentology 34, 973-89.

Fedonkin, M. A. 1987. Paleoichnology of the PrecambrianCambrian transition in the Russian Platform and Siberia. In Trace Fossils, Small Shelly Fossils and the Precambrian-Cambrian Boundary (eds E. Landing, G. M. Narbonne and P. Myrow), p. 12. Bulletin of the New York State Museum no. 463.

Friedman, I. \& O'NeiLl, J. R. 1977. Compilation of stable isotope fractionation factors of geochemical interest. In Data of Geochemistry (ed. M. Fleicher). United States Geological Survey Professional Paper N 440-KK, Washington D.C., 110 pp.

GAO, G. \& LAND, L. S. 1991. Geochemistry of CambroOrdovician Arbuckle limestone, Oklohoma: implications for diagenetic $\delta^{18} \mathrm{O}$ alteration and secular $\delta^{13} \mathrm{C}$ and ${ }^{87} \mathrm{Sr} /{ }^{86} \mathrm{Sr}$ variation. Geochimica et Cosmochimica Acta $\mathbf{5 5}$, 2911-20.

Gibsher, A. S., Bat-Ireedui, Y. A., Balakhonov, I. G. \& EFREMENKO, D. E. 1991. The Bayan Gol reference section of the Vendian-Lower Cambrian in central Mongolia (subdivision and correlation). In Late Precambrian and Early Palaeozoic of Siberia. Siberian Platform and its framework (ed. V.V. Khomentovsky), pp. 107-20. Novosibirsk: Ob'edinennyy Institut Geologii, Geofiziki i Mineralogii, Sibirskoe Otdelenie, Akademiya Nauk SSSR, $151 \mathrm{pp}$. (in Russian).

GiBSHER, A. S. \& KHOMENTOvSKy, V. V. 1990. The sections of the Tsagan Oloom and Bayan Gol formations of the Vendian-Lower Cambrian in the Dzabkhan zone of Mongolia. Pozdniy Dokembriy i Ranniy Paleozoy Sibiri. Voprosy Regional'noy Stratigraphii, pp. 79-91. Novosibirsk: Izdateltsvo Instituta Geologii i Geofiziki (in Russian).

GoldRING, R. \& JENSEN, S. 1996. Trace fossils and biofabrics at the Precambrian-Cambrian boundary interval in western Mongolia. Geological Magazine 133, 403-15.

Gorokhov, I. M., Semikhatov, M. A., Basakov, A. V., Kuyavin, E. P., Mel'nikov, N. N., Sochava, A. V. \& TURCHENKo, T. L. 1995. Sr isotopic composition in Riphean, Vendian and Lower Cambrian carbonates from Siberia. Stratigraphy and Geological Correlation 3, 1-28.

GraNT, S. W. F. 1992. Carbon isotopic vital effect and organic diagenesis, Lower Cambrian Forteau Formation, northwest Newfoundland: implications for $\delta^{13} \mathrm{C}$ chemostratigraphy. Geology 20, 243-6.

HAMDI, B. 1989. Stratigraphy and palaeontology of the Late Precambrian to early Cambrian in the Alborz Mountains, northern Iran. Geological Survey of Iran, Report 59, 41 pp., 6 pls.

Hudson, J. D. 1977. Stable isotopes and limestone lithification. Journal of the Geological Society, London 136, 157-64. 
ILYIN, A. V. 1982. Geological development of Southern Siberia and Mongolia in the late Precambrian-Cambrian. Moscow: Nauka, 116 pp. (in Russian).

IYeR, S. S., Babinski, M., KRouse, H. R. \& Chemale, F. JR. 1995. Highly ${ }^{13} \mathrm{C}$-enriched carbonate and organic matter in the Neoproterozoic sediments of the Bambui Group, Brazil. Precambrian Research 73, 271-82.

Irwin, H., CurTis, C. \& Coleman, M. 1977. Isotopic evidence for source of diagenetic carbonates formed during burial of organic-rich sediments. Nature 269, 209-13.

Kaufman, A. J., Hayes, J. M., Knoll, A. H. \& Germs, G. J. B. 1991. Isotopic compositions of carbonates and organic carbon from upper Proterozoic successions in Namibia: stratigraphic variation and the effects of diagenesis and metamorphism. Precambrian Research 49, 301-27.

Kaufman, A. J., Jacobsen, S. B. \& Knoll, A. H. 1993. The Vendian record of $\mathrm{Sr}$ and $\mathrm{C}$ isotopic variations in seawater: implications for tectonics and palaeoclimate. Earth and Planetary Science Letters 120, 409-30.

KaufMan, A. J. \& KNOLL, A. H. 1995. Neoproterozoic variations in the C-isotopic composition of seawater: stratigraphic and biogeochemical implications. Precambrian Research 73, 27-49.

Kaufman, A. J., Knoll, A. H., Semikhatov, M. A., Grotzinger, J. P., Jacobsen, S. B. \& Adams, W. 1996. Isotopic chemostratigraphy of Proterozoic-Cambrian boundary beds in the western Anabar region, Northern Siberia. Geological Magazine 133, in press.

Kepezhinskas, P. K., Kepezhinskas, K. B. \& Pukhtel, I. S. 1991. Lower Paleozoic oceanic crust in Mongolian Caledonides: $\mathrm{Sm} / \mathrm{Nd}$ isotope and trace element data. Geophysical Research Letters 18(7), 1301-4.

КномеNTOVSKY, V. V. \& GiBSHER, A. S. 1996. The Neoproterozoic-lower Cambrian in northern Govi-Altay, western Mongolia: regional setting, lithostratigraphy and biostratigraphy. Geological Magazine 133, 371-90.

Khomentovsky, V. V. \& Karlova, G. A. 1993. Biostratigraphy of the Vendian-Cambrian beds and the lower Cambrian boundary in Siberia. Geological Magazine 130, 29-45.

KirschVink, J., Magaritz, M., Ripperdan, R. L., Zhuravlev, A. Yu. \& Rozanov, A. Yu. 1991. The Precambrian/Cambrian boundary: magnetostratigraphy and carbon isotopes resolve correlation problems between Siberia, Morrocco and south China. GSA Today 1, 69-71, 87,91 .

Knoll, A. H., Grotzinger, J. P., Kaufman, A. J. \& Kolosov, P. 1995. Integrated approaches to terminal Proterozoic stratigraphy: an example from the Olenek Uplift, northeastern Siberia. Precambrian Research 73, 251-70.

Knoll, A. H., Hayes, J. M., Kaufman, A. J., Swett, K. \& LAMBERT, I. B. 1986. Secular cariations in carbon isotope ratios from Upper Proterozoic successions of Svalbard and East Greenland. Nature 321, 832-8.

Knoll, A. H., Kaufman, A. J., Semikhatov, M. A., Grotzinger, J. P. \& ADAMS, W. 1995. Sizing up the subTommotian unconformity in Siberia. Geology 23, $1139-43$.

KоRовоv, M. N. 1980. Lower Cambrian biostratigraphy and miomeroid trilobites of the Lower Cambrian of Mongolia. In Lower Cambrian and Carboniferous biostratigraphy of Mongolia (eds V. V. Menner and S. V. Meyen), pp. 601-15. Trudy Sovmestnoy Sovetsoko-Mongol'skoy Paleontologicheskoy Ekspeditsii, Moscow 26, (in Russian).

KoRobov, M. N. \& MisSARZHevsKy, V. V. 1977. On the Cambrian and Precambrian boundary layers of western
Mongolia. In Palaeozoic Invertebrata of Mongolia (eds L.P. Tartarinov and others), pp. 7-9. Trudy Sovmestnaya Sovetsko-Mongol'skaya Paleontologicheskaya Ekspeditsiya, Moscow 5, (in Russian).

LAmbert, I. B., Walter, M. R., Zang Wenglong, Lu Songnian \& MA Guogan. 1987. Palaeoenvironment and carbon isotope stratigraphy of upper Proterozoic carbonates of the Yangtze Platform. Nature 325, 140-2.

LESNOV, F. P. 1993. Multistage formation of mafic-ultramafic plutonic complexes of ophiolite associations. Fourth International Symposium on Geodynamic evolution of Palaeo-Asian ocean, pp. 97-9. IGCP Project 282 Report no. 4. Novosibirsk.

Lindsay, J. F., Brasier, M. D., DorjnamuaA, D., Goldring, R., KruSE, P. D. \& WOOD, R. A. 1996a. Facies and sequence controls on the appearance of the Cambrian biota in southwestern Mongolia: implications for Precambrian-Cambrian boundary. Geological Magazine 133, 417-28.

Lindsay, J. F., Brasier, M. D., Shields, G., Khomentovsky, V. V. \& BAT-IREEDUI, Y. A. 1996b. Glacial facies associations in a Neoproterozoic back-arc setting, Zavkhan Basin, western Mongolia. Geological Magazine 133, 391-402.

MagaritZ, M. $1989 .{ }^{13} \mathrm{C}$ minima follow extinction events: a clue to faunal radiation. Geology 17, 337-40.

Magaritz, M., Holser, W. T. \& KirchVink, J. L. 1986. Carbon-isotope events across the Precambrian-Cambrian boundary on the Siberian Platform. Nature 320, 258-9.

Magaritz, M., Kirschvink, J. L., Latham, A. J., ZhuraVlev, A. YU. \& Rozanov, A. Yu. 1991. Precambrian/Cambrian boundary problem: carbon isotope correlations for Vendian and Tommotian time between Siberia and Morocco. Geology 19, 847-50.

Markova, N. P. 1975. Stratigraphy of the Lower and Middle Paleozoic of Western Mongolia. Moscow: Nauka, 120 pp. (in Russian).

Markova, N. P., Korobov, N. M. \& Zhuravleva, Z. A. 1972. On the problem of the Vendian-Cambrian of the south-western part of Mongolia. Byulleten' Moskovskogo Obschchestva Ispytateley Prirody, Otdelenie Geologicheskiy 47, 57-70 (in Russian).

MissarzheVSKY, V. V. 1977. Conodonts (?) and phosphatic problematica from the Cambrian of Mongolia and Siberia. In Palaeozoic Invertebrata of Mongolia (eds L. P. Tartarinov and others), pp. 10-19. Trudy Sovmestnaya SovetskoMongol'skaya Paleontologicheskaya Ekspeditsiya, Moscow 5 (in Russian).

MISSARZHEVSKY, V. V. 1982. Raschlenenie i korrelyatsia pogranichnykh tolshch dokembriya i kembriya po nekotorym problematichnym gruppam skeletnykh okamenelostey. Byulleten' Moskovskogo Obschchestva Ispyateley Prirody, Otdelenie Geologicheskiy 57, 52-68.

NarbonNe, G. M., Kaufman, A. J. \& KNOLL, A. H. 1994. Integrated chemostratigraphy and biostratigraphy of the Windermere Supergroup, northwestern Canada: implications for Neoproterozoic correlations and early evolution of animals. Bulletin of the Geological Society of America 106,1281-92.

Nicholas, C. J. 1996. The Sr isotope evolution of the oceans during the 'Cambrian Explosion'. Journal of the Geological Society, London, 153, 243-54.

Pelechaty, S. M., Kaufman, A. K. \& Grotzinger, J. P. In press. Evaluation of $\delta^{13} \mathrm{C}$ isotope stratigraphy for intrabasinal correlation: Vendian strata of the Olenek uplift and Kharaulakh Mountains, Siberian platform, Russia. Bulletin of the Geological Society of America. 
Pokrovsky, B. G. \& Missarzhevsky, V. V. 1993. Isotopic correlation of Precambrian and Cambrian of the Siberian platform. Doklady Akademy Nauk 329, 768-7I (in Russian).

PrEISS, W. 1976. The biostratigraphic potential of Precambrian stromatolites. Precambrian Research 5, 207-19.

RAABEN, M. Y. \& ZABRODIN, V. Y. 1969. Biostratigraphic characteristics of the Upper Riphean in the Arctic. Doklady Akademii Nauk, SSR 184, 676-9.

RIPPERDAN, R. 1994. Global variations in carbon isotope composition during the latest Neoproterozoic and earliest Cambrian. Annual Review of Earth and Planetary Sciences 22, 385-417.

Rosenbaum, I. \& Sheppard, S. M. F. 1986. An isotopic study of siderites, dolomites and ankerites at high temperature. Geochimica et Cosmochimica Acta 50, 1147-50.

Rozanov, A. YU. 1992. Some problems concerning the Precambrian-Cambrian transition and the Cambrian faunal radiation. Journal of the Geological Society, London 149, 593-8.

SaYUTina, T. A. 1985. Cribricyaths of the lower Cambrian from Mongolia. In Problematics of the Precambrian and Palaeozoic (eds B.S. Sokolov and I.T. Zhuravleva), pp. 38-44. Transactions of the Institute of Geology and Geophysics, Siberian Branch, USSR Academy of Sciences 632, (in Russian).

Şengör, A. M. C., Natal'in, B. A. \& Burtman, V. S. 1993. Evolution of the Altaid tectonic collage and Palaeozoic crustal growth in Eurasia. Nature 364, 299-307.

ShEPPARD, S. M. F. \& SCHWARCZ, H. P. 1970. Fractionation of carbon and oxygen isotopes and magnesium between coexisting metamorphic calcite and dolomite. Contributions to Mineralogy and Petrology 26, 161-98.

SMith, L. H., KaUfman, A. J., KNOLL, A. H. \& LinK, P. K. 1994. Chemostratigraphy of predominantly siliciclastic Neoproterozoic successions: a case study of the Pocatello Formation and Lower Brigham Group, Idaho, USA. Geological Magazine 131, 301-14.

STEIGER, R. H. \& JAEGER, E. 1977. Subcommission on geochronology: convention on the use of decay constants in geo- and cosmochronology. Earth and Planetary Science Letters 36, 359-62.

USHATINSKAYA, G. T. 1993. New genus of paterinid (brachiopod) from the Lower Cambrian of western Mongolia Paleontological Zhurnal 1, 115-18 (in Russian).

UshatinSKAYA, G. T. 1995. The earliest lingulates. Rossiyskaya Akademiya Nauk, Paleontologicheskaya Institut, Trudy 262,91 pp. (in Russian).

VIDAL, G., MoczYdlowsKa, M. \& Rudavskaya, V. R. 1995. Constraints on the early Cambrian radiatio and correlation of the Tommotian and Nemakit-Daldynian regional stages of eastern Siberia. Journal of the Geological Society, London 152, 499-510.

Voronin, Yu. I., Voronova, L. G., Drozdova, N. A. Zhuravlev, A. Yu., Rozanov, A. Yu., Sayutina, T. A. \& Fonin, V. D. 1983. Precambrian-Cambrian deposits of the Zuune Arts section in Western Mongolia. Byulleten Moskovskogo Obschestva Ispytateley Prirody, Otdel Geologicheskiy 58, 53-66 (in Russian)

Voronin, Yu. I., Voronova, L. G., Grigor'Eva, N. V., Drozdova, N. A., Zhegallo, E. A., Zhuravlev, A. Yu., Ragozina, A. L., Rozanov, A. Yu., Sayutina, T. A., Sysoev, V. A. \& Fonin, V. D. 1982. The Precambrian/Cambrian boundary in the geosynclinal areas (the reference section of Salaany-Gol, MPR). Trudy Sovmestnaya Sovetsko-Mongol'skaya Paleontologicheskaya Ekspeditsiya, Moscow 18, 180 pp. (in Russian).

Voronova, L. G., Voronin, Yu. I., Drozdova, N. A., Esakova, N. V., Zhegallo, E. A., ZhuraVleV, A. Yu., LuChinina, V. A., Meshrova, N. P., Ragozina, A. L., Sayutina, T. A. \& FonIN, V. D. 1986. Organic remains in the Lower Cambrian strata of the Zavkhan and Khungiy interfluve (Mongolia). Akademiya Nauk SSSR, Sibirskoe Otdelinie, Institut Geologii i Geofiziki, Trudy 669, 163-8 (in Russian).

Walters, H. I., Claypool, I. G. E. \& Philip, C. W. 1972. Reaction rate and ${ }^{18} \mathrm{O}$ acid preparation method Geochimica et Cosmochimica Acta 36, 120-40.

Wood, R., Zhuravlev, A. Yu. \& Chimed Tseren, A. 1993. The ecology of Lower Cambrian buildups from Zuune Arts, Mongolia: implications for early metazoan reef evolution. Sedimentology $40,829-58$.

Zhegallo, L. \& ZhuRAVlev, A. YU. 1991. Guidebook for the International excursion to the Vendian-Cambrian deposits of the Dzabkhan Zone of Mongolia. Unpublished guidebook, Palaeontological Institute, Moscow, 24 pp.

\section{Appendix}

Table 1. Strontium isotope and elemental composition of carbonates from the Neoproterozoic-Cambrian of southwest Mongolia (Figs. 4, 12 and 13)

\begin{tabular}{|c|c|c|c|c|c|c|c|}
\hline Sample & Strat. height & $\mathrm{Sr}(\mathrm{ppm})$ & $\mathrm{Mn}(\mathrm{ppm})$ & $\mathrm{Fe}(\mathrm{ppm})$ & $\%$ dissolution & $\mathrm{Mg} / \mathrm{Ca} \times 100$ & $87 \mathrm{Sr} / 86 \mathrm{Sr}$ \\
\hline \multicolumn{8}{|c|}{ Tsagaan Oloom Fm. } \\
\hline Tsag. 1 & 0.400 & 2900.000 & 225.000 & 117.000 & 95.000 & 0.190 & 0.706754 \\
\hline Tayshir 2 & 4.000 & 1350.000 & 303.000 & 522.000 & 94.000 & 0.540 & 0.706796 \\
\hline Tsag. 2* & 10.000 & 960.000 & 124.000 & 103.000 & 77.000 & 0.330 & 0.706990 \\
\hline Tsag. 3 & 16.000 & 1500.000 & 140.000 & 217.000 & 94.000 & 0.220 & 0.706944 \\
\hline Tsag. 4 & 22.000 & 1060.000 & 157.000 & 153.000 & 96.000 & 0.200 & 0.707050 \\
\hline Tsag. 5 & 30.000 & 1500.000 & 156.000 & 2000.000 & 91.000 & 0.240 & 0.707094 \\
\hline Tsag. 6 & 35.000 & 650.000 & 15.000 & 20.000 & 98.000 & & 0.707200 \\
\hline Tsag. 7 & 40.000 & 1700.000 & 12.000 & 30.000 & 97.000 & 0.130 & 0.707164 \\
\hline Tsag. 8 & 45.000 & 950.000 & 18.000 & 35.000 & 97.000 & 0.150 & 0.707224 \\
\hline Tsag. 9* & 50.000 & & 13.000 & 20.000 & 97.000 & & 0.707288 \\
\hline Tsag. 19-TS7* & 360.000 & 934.000 & & & & & 0.707345 \\
\hline Tsag. 20-TS8* & 380.000 & 1110.000 & & & & & 0.707247 \\
\hline Tsag. 11* & 392.000 & & & & 95.000 & & 0.708273 \\
\hline Tsag. 20-TS9* & 430.000 & 60.000 & & & & & 0.707253 \\
\hline Tsag. 20-TS10* & 475.000 & 2043.000 & & & & & 0.707693 \\
\hline
\end{tabular}


Table 1 (cont.)

\begin{tabular}{|c|c|c|c|c|c|c|c|}
\hline Sample & Strat. height & $\mathrm{Sr}(\mathrm{ppm})$ & $\mathrm{Mn}(\mathrm{ppm})$ & $\mathrm{Fe}(\mathrm{ppm})$ & $\%$ dissolution & $\mathrm{Mg} / \mathrm{Ca} \times 100$ & $87 \mathrm{Sr} / 86 \mathrm{Sr}$ \\
\hline Tsag. 12* & 510.000 & & & & & & 0.707864 \\
\hline Tsag. 13* & 520.000 & & & & 97.000 & & 0.708297 \\
\hline Tsag. 14* & 530.000 & 95.000 & 86.000 & 1400.000 & 87.000 & 0.220 & 0.708355 \\
\hline Tsag. $16^{*}$ & 540.000 & 1500.000 & 100.000 & 1300.000 & 60.000 & 0.210 & 0.707887 \\
\hline KTN 1* & 554.000 & 45.000 & 120.000 & 788.000 & 98.000 & & 0.707856 \\
\hline KTN 2* & 559.000 & 39.500 & 45.000 & 1154.000 & 98.000 & & 0.708095 \\
\hline Tsag. 21 & 564.000 & 2300.000 & 26.000 & 128.000 & 94.000 & 0.130 & 0.707871 \\
\hline KTN 3* & 564.000 & 43.000 & 52.000 & 1308.000 & 98.000 & & 0.708050 \\
\hline KTN 4* & 569.000 & 34.000 & 30.000 & 438.000 & 98.000 & & 0.708122 \\
\hline Bay Sla* & 596.000 & 122.000 & 204.000 & 1100.000 & 73.000 & & 0.708640 \\
\hline Bay S0 & 598.000 & 990.000 & 183.000 & 1070.000 & 86.000 & 0.280 & 0.708530 \\
\hline Tsag. 20 & 618.000 & 2300.000 & 28.000 & 410.000 & 90.000 & 0.170 & 0.708417 \\
\hline Bay $\$ 4$ & 618.000 & 620.000 & 38.000 & 150.000 & 95.000 & 0.470 & 0.708527 \\
\hline Bay \$5 & 623.000 & 755.000 & 114.000 & 266.000 & 97.000 & 0.420 & 0.708425 \\
\hline Tsag. 24 & 780.000 & 1080.000 & 165.000 & 901.000 & 94.000 & 0.120 & 0.708553 \\
\hline Bay. By O2 & 800.000 & 550.000 & 10.000 & 46.000 & 96.000 & & 0.708430 \\
\hline Bay. Bdl4* & 800.000 & 510.000 & 1170.000 & 571.000 & 98.000 & & 0.708487 \\
\hline Bay $2^{*}$ & 837.000 & 520.000 & 113.000 & 1170.000 & 96.000 & & 0.708562 \\
\hline Bay 4* & 847.000 & 1090.000 & 1600.000 & 1220.000 & 97.000 & 0.290 & 0.708439 \\
\hline Bay 33 & 870.000 & 620.000 & 79.000 & 476.000 & 95.000 & 0.670 & 0.708458 \\
\hline Tsag. 25* & 870.000 & 284.000 & 39.000 & 306.000 & 86.000 & 0.200 & 0.708478 \\
\hline Bay $40^{*}$ & 880.000 & 1120.000 & 274.000 & 247.000 & 75.000 & 0.510 & 0.708574 \\
\hline Bay $42^{*}$ & 882.000 & 1520.000 & 994.000 & 715.000 & 66.000 & 0.570 & 0.708648 \\
\hline Bay $44^{*}$ & 890.000 & 1500.000 & 2700.000 & 2010.000 & 77.000 & 0.420 & 0.708500 \\
\hline Tsag. 26* & 895.000 & 980.000 & 332.000 & & 81.000 & 0.220 & 0.708687 \\
\hline \multicolumn{8}{|l|}{ Bayan Gol Fm. } \\
\hline Tsag. 28 & 902.000 & 2200.000 & 43.000 & 650.000 & 88.000 & 0.200 & 0.708427 \\
\hline Tsag. 31* & 990.000 & 433.000 & 70.000 & 219.000 & 98.000 & 0.110 & 0.708537 \\
\hline Tsag. 32* & 990.000 & 491.000 & 175.000 & 790.000 & 90.000 & 0.170 & 0.708887 \\
\hline Tsag. 34 & 1030.000 & 1600.000 & 283.000 & 1400.000 & 86.000 & 0.210 & 0.708726 \\
\hline Bay $45^{*}$ & 1063.000 & 1200.000 & 5000.000 & 1560.000 & 42.000 & 0.430 & 0.708674 \\
\hline Bay 56 & 1122.000 & 1280.000 & 73.000 & 109.000 & 98.000 & 0.210 & 0.708494 \\
\hline Sal By 14 & 1150.000 & 1020.000 & 830.000 & 830.000 & 94.000 & 0.320 & 0.708492 \\
\hline Sal By 2l & 1202.000 & 2200.000 & 71.000 & 561.000 & 93.000 & 0.340 & 0.708462 \\
\hline Sal. By $22 b$ & 1207.000 & 1140.000 & 106.000 & 683.000 & 97.000 & 0.350 & 0.708467 \\
\hline Sal By 25 & 1350.000 & 740.000 & 116.000 & 312.000 & 92.000 & & 0.708480 \\
\hline Sal By 25 & 1350.000 & 740.000 & 116.000 & 312.000 & 92.000 & & 0.708480 \\
\hline Bay 21-B $64 *$ & 1358.000 & 1000.000 & 196.000 & 1050.000 & 65.000 & 0.510 & 0.708437 \\
\hline Bay 21-B65* & 1360.000 & 1070.000 & & 840.000 & 98.000 & 0.520 & 0.708541 \\
\hline Sal. By 26 & 1360.000 & 600.000 & 105.000 & 194.000 & 89.000 & & 0.708452 \\
\hline Sal By 26 & 1360.000 & 600.000 & 105.000 & 194.000 & 89.000 & & 0.708452 \\
\hline Bay 21-B66 & 1366.000 & 2350.000 & 68.000 & 536.000 & 96.000 & 0.660 & 0.708549 \\
\hline Bay $21-B 71 *$ & 1419.000 & 840.000 & 94.000 & 549.000 & 75.000 & 0.300 & 0.708876 \\
\hline Bay $21-B 72 *$ & 1424.000 & 350.000 & 55.000 & 246.000 & 91.000 & 0.210 & 0.708784 \\
\hline Bay 21 B $73^{*}$ & 1429.000 & 380.000 & 48.000 & 169.000 & 97.000 & 0.260 & 0.708502 \\
\hline Sal. By $36^{*}$ & 1683.000 & 510.000 & 378.000 & 636.000 & 94.000 & & 0.708829 \\
\hline Sal By 36* & 1683.000 & 510.000 & 378.000 & 636.000 & 94.000 & & 0.708835 \\
\hline Sal. By47 & 2193.000 & 1700.000 & 417.000 & 2600.000 & 87.000 & 0.360 & 0.708313 \\
\hline Sal. By48 & 2201.000 & 2000.000 & 470.000 & 765.000 & 96.000 & 0.260 & 0.708283 \\
\hline Sal. By $49^{*}$ & 2230.000 & 290.000 & 633.000 & 189.000 & 85.000 & 0.190 & 0.708476 \\
\hline \multicolumn{8}{|l|}{ Salaany Gol Fm. } \\
\hline $\mathrm{ZA}-8(2)$ & 2463.000 & 740.000 & 183.000 & 1400.000 & 87.000 & 0.470 & 0.708165 \\
\hline Sal. SGI(e.a)* & 2650.000 & 271.000 & 161.000 & 484.000 & 97.000 & 0.300 & 0.708194 \\
\hline Sal. SGI $(\mathrm{HCl})^{*}$ & 2650.000 & 323.000 & 160.000 & 457.000 & 97.000 & 0.300 & 0.708215 \\
\hline Sal. SGI* & 2650.000 & 350.000 & 160.000 & 300.000 & 97.000 & 0.300 & 0.708195 \\
\hline Sal. SG3w* & 2660.000 & & & & 96.000 & & 0.708134 \\
\hline Sal. SG3r* & 2660.000 & & & & 96.000 & & 0.708211 \\
\hline Tayshir 1* & 1600.000 & 750.000 & 1010.000 & 2300.000 & 92.000 & & 0.708350 \\
\hline Al & 2400.000 & 600.000 & 349.000 & 650.000 & 94.000 & 0.280 & 0.708053 \\
\hline \multicolumn{8}{|l|}{ Khayrkhan Fm. } \\
\hline Sal. KHm* & 2735.000 & & & & 90.000 & & 0.708293 \\
\hline Sal. KHr* & 2735.000 & & & & 90.000 & & 0.708339 \\
\hline
\end{tabular}

The sample numbers give the locality, followed by the field collection number. Tsag., Tsagaan Gol; KTN, Khevte-Tsakhir-Nuruu; Bay, Bayan Gol; Tayshir section (see Lindsay et al. 1996b, this issue); Sal, Salaany Gol; ZA, Zuune Arts; A, Govi-Altay ophiolite complex. The stratigraphic height (metres) for this and following tables is calculated from the composite scale (Figs. 11-13). Two samples have less certain stratigraphic heights, estimated within the following limits: Tayshir $1(1600-1900 \mathrm{~m})$; Al (2400-2700 m). Oxford analyses = Tsag. 19-TS7 to Tsag. 20-TS10; rest are ETH and Strasbourg analyses. Blank spaces $=$ not measured or did not run. Samples Tsag 11 and KTN 1 to 4 were predominantly dolomite, and $\mathrm{Mg} / \mathrm{Ca}$ ratios were not measured. Asterisks mark those samples considered to be 'suspect' samples (as opposed to 'least-altered' samples) on the basis of high $\mathrm{Mn} / \mathrm{Sr}$ $>0.6, \mathrm{Fe} / \mathrm{Sr} 3.0, \mathrm{Sr}<550 \mathrm{ppm}$ or $>15 \%$ acetic acid insoluble residue. Samples whose trace element chemistries are not known, or which are dolomitic, are automatically considered to be 'suspect' (see Figs 4, 12 and 13). All geochemical data displayed have been obtained from the acetic acid soluble fraction of the samples, except in the cases of dolomites. 
Table 2. Carbon and oxygen isotopic composition of carbonates in the Tsagaan Gol section (Fig. 5)

\begin{tabular}{|c|c|c|c|c|c|}
\hline Sample & Height (m) & Lithology & $\delta^{13} \mathrm{C}$ & $\delta^{18} \mathrm{O}$ & Formation \\
\hline 16-TSI & 0.300 & C bmud lam & -0.5 & -8.1 & Tsagaan Oloom \\
\hline 16-TS1 & 0.300 & Cbmud lam & -0.5 & -5.8 & Tsagaan Oloom \\
\hline 16-TS2* & 5.300 & C bmud lam & -1.5 & -16.7 & Tsagaan Oloom \\
\hline 16-TS2* & 5.300 & C bmud lam & -1.8 & -16.7 & Tsagaan Oloom \\
\hline 16-TS3* & 12.300 & $\mathrm{C}$ bmud pel org & -1.1 & -14.1 & Tsagaan Oloom \\
\hline 16-TS3* & 12.300 & $\mathrm{C}$ bmud pel org & -0.9 & -14.3 & Tsagaan Oloom \\
\hline 16-VKI-3352 & 14.000 & Calcite & 0.4 & -11.0 & Tsagaan Oloom \\
\hline 16-TS4 & 15.300 & C bmud pel org & 0.1 & -14.2 & Tsagaan Oloom \\
\hline 16-TS4 & 15.300 & C bmud pel org & 0.5 & -11.5 & Tsagaan Oloom \\
\hline $18-V K 2-3358$ & 56.000 & Calcite & 1.6 & -13.8 & Tsagaan Oloom \\
\hline 18-VK3-3358 & 56.000 & Dolomite & 2.7 & -11.5 & Tsagaan Oloom \\
\hline 18-TS5* & 61.000 & FC bmud lam & 1.3 & -10.9 & Tsagaan Oloom \\
\hline 18-TS5* & 61.000 & FC bmud lam & 1.9 & -9.4 & Tsagaan Oloom \\
\hline $18-V K 4-3360$ & 66.000 & Calcite & 8.0 & -6.9 & Tsagaan Oloom \\
\hline 18-VK5-3361 & 81.000 & Calcite & 7.8 & -10.2 & Tsagaan Oloom \\
\hline 18-VK6-3362 & 96.000 & Calcite & 9.1 & -4.0 & Tsagaan Oloom \\
\hline $18-\mathrm{VK} 7-3363$ & 101.000 & Calcite & 6.0 & -7.8 & Tsagaan Oloom \\
\hline 19-VK8-3364 & 120.000 & Calcite & 6.8 & -8.1 & Tsagaan Oloom \\
\hline 19-VK9-3365 & 140.000 & Calcite & 4.7 & -9.6 & Tsagaan Oloom \\
\hline 19-VK10-3368 & 160.000 & Calcite & 8.9 & -8.3 & Tsagaan Oloom \\
\hline 19-VK11-3367 & 180.000 & Calcite & 9.1 & -7.8 & Tsagaan Oloom \\
\hline $19-\mathrm{VK} 12-3368$ & 205.000 & Dolomite & 11.0 & -2.3 & Tsagaan Oloom \\
\hline 19-VK13-3369 & 220.000 & Calcite & 10.0 & -4.8 & Tsagaan Oloom \\
\hline $19-\mathrm{VK}-3370$ & 235.000 & Calcite vein & 4.0 & -30.4 & Tsagaan Oloom \\
\hline 19-VK14-337I & 245.000 & Calcite & 9.8 & -2.8 & Tsagaan Oloom \\
\hline 19-VK15-3372 & 260.000 & Calcite & 10.3 & -2.7 & Tsagaan Oloom \\
\hline 19-VK16-3373 & 275.000 & Dolomite & 10.7 & -2.1 & Tsagaan Oloom \\
\hline 19-VK17-3375 & 285.000 & Calcite & 11.0 & -0.4 & Tsagaan Oloom \\
\hline 19-VK18-3376 & 305.000 & Calcite & 10.3 & -3.8 & Tsagaan Oloom \\
\hline 19-VK $19-3377$ & 315.000 & Calcite & 10.2 & -3.8 & Tsagaan Oloom \\
\hline 19-VK20-3378 & 335.000 & Calcite & 10.0 & -3.9 & Tsagaan Oloom \\
\hline 19-TS7 & 360.000 & C blam vg spar & 9.3 & -6.2 & Tsagaan Oloom \\
\hline 19-TS7 & 360.000 & C blam vg spar & 9.6 & -4.1 & Tsagaan Oloom \\
\hline 19-VK22-3379 & 365.000 & Calcite & 10.8 & -2.8 & Tsagaan Oloom \\
\hline $20-V K 23-3380$ & 379.000 & Dolomite & 11.4 & -4.8 & Tsagaan Oloom \\
\hline 20-TS8 & 380.000 & $\mathrm{Cb}$ onc spar & 11.1 & -3.9 & Tsagaan Oloom \\
\hline 20-TS8 & 380.000 & C b onc spar & 10.7 & -4.2 & Tsagaan Oloom \\
\hline 20-VK24-338I & 381.000 & Dolomite & 3.4 & -2.2 & Tsagaan Oloom \\
\hline 20-VK25-3382 & 387.000 & Dolomite & 2.8 & -13.1 & Tsagaan Oloom \\
\hline $20-$ VK26-3383 & 392.000 & Dolomite & 3.3 & -4.6 & Tsagaan Oloom \\
\hline 20-VK27-3385 & 397.000 & Calcite & 6.5 & -7.9 & Tsagaan Oloom \\
\hline 20-VK28-3387 & 400.000 & Calcite & 6.4 & -8.5 & Tsagaan Oloom \\
\hline 20-VK28-3387 & 400.000 & Dolomite & 2.6 & -5.8 & Tsagaan Oloom \\
\hline 20-VK-29-338 & 410.000 & Dolomite & 8.0 & -9.1 & Tsagaan Oloom \\
\hline 20-VK30-3389 & 415.000 & Dolomite & 3.2 & -8.0 & Tsagaan Oloom \\
\hline $20-V K 31-3390$ & 425.000 & Dolomite & 2.2 & -6.8 & Tsagaan Oloom \\
\hline 20-TS9 & 430.000 & D mud ic & 4.9 & -5.0 & Tsagaan Oloom \\
\hline 20-TS9 & 430.000 & D mud ic & 6.5 & -5.6 & Tsagaan Oloom \\
\hline 20-VK32-339l & 445.000 & Calcite & 5.6 & -11.0 & Tsagaan Oloom \\
\hline 20-VK33-3302 & 455.000 & Dolomite & 8.0 & -5.5 & Tsagaan Oloom \\
\hline 20-VK33-3392 & 455.000 & Calcite & 5.8 & -11.0 & Tsagaan Oloom \\
\hline 20-VK34-3393 & 472.000 & Calcite & 7.6 & -11.3 & Tsagaan Oloom \\
\hline 20-VK34-3393 & 472.000 & Dolomite & 8.0 & -9.3 & Tsagaan Oloom \\
\hline 20-TS 10 & 475.000 & D bmud ic org & 7.6 & -11.3 & Tsagaan Oloom \\
\hline 20-TS10 & 475.000 & D bmud ic org & 7.5 & -8.5 & Tsagaan Oloom \\
\hline 21-VK35-3394 & 482.000 & Dolomite & 6.6 & -9.9 & Tsagaan Oloom \\
\hline 21-TS11 & 484.000 & D mud pel & 4.3 & -3.6 & Tsagaan Oloom \\
\hline 21-TS11 & 484.000 & D mud pel & 0.0 & -8.7 & Tsagaan Oloom \\
\hline 21-VK36-3395 & 497.000 & Calcite & 5.3 & -11.3 & Tsagaan Oloom \\
\hline 21-VK36-3395 & 497.000 & Dolomite & 3.6 & -9.3 & Tsagaan Oloom \\
\hline 22-TS12 & 510.000 & C mud pel spar & 5.3 & -8.4 & Tsagaan Oloom \\
\hline 22-TS 12 & 510.000 & C mud pel spar & 4.8 & -8.8 & Tsagaan Oloom \\
\hline 22-VK37-3396 & 521.500 & Calcite & 8.2 & -9.3 & Tsagaan Oloom \\
\hline 22-VK38-3397 & 529.000 & Dolomite & 4.2 & -3.3 & Tsagaan Oloom \\
\hline 22-VK39-3398 & 546.000 & Dolomite & 3.5 & -4.2 & Tsagaan Oloom \\
\hline $22-\mathrm{TS} 13$ & 564.000 & C wkst pel ic & 4.7 & -7.9 & Tsagaan Oloom \\
\hline $22-\mathrm{TS} 13$ & 564.000 & C wkst pel ic & 4.5 & -8.2 & Tsagaan Oloom \\
\hline 23-VK40-3399 & 569.000 & Dolomite & 1.8 & -4.1 & Tsagaan Oloom \\
\hline 23-TS15* & 571.000 & FD mud lam & 3.3 & -2.8 & Tsagaan Oloom \\
\hline 23-TS15* & 571.000 & FD mud lam & -0.3 & -2.3 & Tsagaan Oloom \\
\hline 23-TS16 & 576.000 & D wkst ic & 3.6 & -1.7 & Tsagaan Oloom \\
\hline 23-TS 16 & 576.000 & D wkst ic & 3.7 & -1.0 & Tsagaan Oloom \\
\hline
\end{tabular}


Table 2 (cont.)

\begin{tabular}{|c|c|c|c|c|c|}
\hline Sample & Height (m) & Lithology & $\delta^{13} \mathrm{C}$ & $\delta^{18} \mathrm{O}$ & Formation \\
\hline 23-TS 17 & 582.000 & D mud spar & 3.3 & -0.8 & Tsagaan Oloom \\
\hline 23-TS17 & 582.000 & D mud spar & 3.4 & -0.0 & Tsagaan Oloom \\
\hline 23-TS18 & 587.000 & D mud cmb FDv & 2.3 & -1.4 & Tsagaan Oloom \\
\hline 23-TS18 & 587.000 & D mud cmb FDv & 2.4 & -2.9 & Tsagaan Oloom \\
\hline 23-VK4I-3400 & 590.000 & Dolomite & 2.2 & -3.6 & Tsagaan Oloom \\
\hline 23-TS 19 & 592.000 & D onc grst $P$ & -0.6 & -2.5 & Tsagaan Oloom \\
\hline 23-TS19 & 592.000 & D onc grst $P$ & -0.6 & -0.5 & Tsagaan Oloom \\
\hline 23-TS20 & 595.000 & D strom spar vg & 0.8 & -0.5 & Tsagaan Oloom \\
\hline 23-TS20 & 595.000 & D strom spar vg & -0.6 & -1.8 & Tsagaan Oloom \\
\hline $23-V K 42-3401$ & 595.000 & Dolomite & 2.4 & -4.0 & Tsagaan Oloom \\
\hline 24-TS21* & 597.000 & FD lam in & -0.2 & -3.1 & Tsagaan Oloom \\
\hline 24-TS21* & 597.000 & FD lam in & -0.1 & -3.1 & Tsagaan Oloom \\
\hline 24-TS 14* & 598.000 & FD lam spar $P$ & -0.3 & -5.8 & Tsagaan Oloom \\
\hline 24-TS $14 *$ & 598.000 & FD lam spar P & -1.7 & -22.9 & Tsagaan Oloom \\
\hline 24-TS23* & 609.000 & FD lam spar $\mathbf{P}$ & -0.3 & -4.8 & Tsagaan Oloom \\
\hline $24-\mathrm{TS} 23^{*}$ & 609.000 & FD lam spar $P$ & 0.8 & -2.5 & Tsagaan Oloom \\
\hline 24-TS24 & 614.000 & D lam spar $P$ & 0.0 & -4.4 & Tsagaan Oloom \\
\hline 24-TS24 & 614.000 & D lam spar $P$ & -0.1 & -4.7 & Tsagaan Oloom \\
\hline 25-TS26 & 618.000 & C mud pel & -0.1 & -12.2 & Tsagaan Oloom \\
\hline 25-TS26 & 618.000 & $\mathrm{C}$ mud pel & 0.3 & -11.7 & Tsagaan Oloom \\
\hline $25-\mathrm{TS} 27^{*}$ & 623.000 & C strom ic & -0.5 & -15.7 & Tsagaan Oloom \\
\hline $25-\mathrm{TS} 27$ & 623.000 & C strom ic & -1.7 & -13.0 & Tsagaan Oloom \\
\hline $25-\mathrm{TS} 28^{*}$ & 628.000 & C wkst ic & 0.2 & -18.8 & Tsagaan Oloom \\
\hline $25-\mathrm{TS} 28$ & 628.000 & C wkst ic & 0.2 & -14.4 & Tsagaan Oloom \\
\hline 25-TS29 & 633.000 & C bwkst ic ch & 0.5 & -11.2 & Tsagaan Oloom \\
\hline 25-TS29 & 633.000 & C bwkst ic ch & 0.3 & -10.8 & Tsagaan Oloom \\
\hline $25-V K 42-3401-1$ & 635.000 & Calcite & -0.2 & -27.3 & Tsagaan Oloom \\
\hline 25-VK43-3402 & 660.000 & Calcite & 0.6 & -14.2 & Tsagaan Oloom \\
\hline $25-V K 44-3403$ & 685.000 & Calcite & -1.3 & -11.3 & Tsagaan Oloom \\
\hline $25-V K 45-3404$ & 700.000 & Dolomite & -2.1 & -9.8 & Tsagaan Oloom \\
\hline 25-VK46-3405 & 745.000 & Dolomite & -4.3 & -9.8 & Tsagaan Oloom \\
\hline $26-V K 47-3406$ & 758.000 & Dolomite & -3.8 & -9.3 & Tsagaan Oloom \\
\hline $26-V K 48-3407$ & 783.000 & Calcite & -5.5 & -10.3 & Tsagaan Oloom \\
\hline 26-VK49-3408 & 808.000 & Calcite & -5.4 & -11.0 & Tsagaan Oloom \\
\hline 26-VK50-3409 & 818.000 & Calcite & -2.1 & -11.0 & Tsagaan Oloom \\
\hline $27-\mathrm{TS} 30$ & 832.000 & C wkst pel v & 0.9 & -13.3 & Tsagaan Oloom \\
\hline 27-TS30 & 832.000 & C wkst pel v & 0.6 & -14.9 & Tsagaan Oloom \\
\hline 27-TS31 & 837.000 & $\mathrm{C}$ bmud lam v & -0.5 & -11.3 & Tsagaan Oloom \\
\hline 27-TS31 & 837.000 & $\mathrm{C}$ bmud lam v & -0.9 & -13.0 & Tsagaan Oloom \\
\hline $27-T S 32$ & 843.000 & $\mathrm{C}$ mud pel v & -1.4 & -9.0 & Tsagaan Oloom \\
\hline 27-TS32 & 843.000 & C mud pel v & -1.4 & -9.2 & Tsagaan Oloom \\
\hline 27-TS33 & 843.000 & C pkst D spar & -1.3 & -8.4 & Tsagaan Oloom \\
\hline 27-TS33 & 85.000 & C pkst D spar & -1.3 & -9.7 & Tsagaan Oloom \\
\hline 27-TS37b & 867.000 & C onc pkst & -0.5 & -11.9 & Tsagaan Oloom \\
\hline 27-TS37b* & 867.000 & C onc pkst & -3.6 & -17.3 & Tsagaan Oloom \\
\hline 27-TS37a & 872.000 & C pkst D spar & -2.2 & -12.4 & Tsagaan Oloom \\
\hline 27-TS37a & 872.000 & C pkst D spar & -2.4 & -12.3 & Tsagaan Oloom \\
\hline 27-TS36 & 877.000 & C grst D spar & -2.7 & -10.0 & Tsagaan Oloom \\
\hline 27-TS36 & 877.000 & C grst D spar & -2.3 & -9.5 & Tsagaan Oloom \\
\hline 27-TS35 & 882.000 & C grst D spar & -1.9 & -11.5 & Tsagaan Oloom \\
\hline 27-TS35 & 883.000 & C grst D spar & -2.1 & -10.7 & Tsagaan Oloom \\
\hline 27-TS34* & 897.000 & Conc grst & -4.6 & -16.1 & Tsagaan Oloom \\
\hline 27-TS34 & 897.000 & C onc grst & -3.9 & -13.6 & Tsagaan Oloom \\
\hline 27-TS40* & 898.000 & C onc grst & -6.2 & -12.7 & Tsagaan Oloom \\
\hline $27-T S 40$ & 898.000 & C onc grst & -5.9 & -12.4 & Tsagaan Oloom \\
\hline 28-TS38* & 902.000 & Cmud D spar P & -2.7 & -16.1 & Bayan Gol \\
\hline 28-TS38* & 902.000 & Cmud D spar P & -3.6 & -16.8 & Bayan Gol \\
\hline 28-TS4I & 903.000 & C mud D spar & -3.5 & -13.9 & Bayan Gol \\
\hline 28-TS41 & 903.000 & $C$ mud D spar & -3.0 & -13.0 & Bayan Gol \\
\hline 28-TS42 & 909.000 & C mud D spar & -2.4 & -12.2 & Bayan Gol \\
\hline 28-TS42 & 909.000 & C mud D spar & -3.3 & -12.2 & Bayan Gol \\
\hline 29-TS43 & 917.000 & $\mathrm{C}$ mud & -0.6 & -14.4 & Bayan Gol \\
\hline 29-TS43 & 917.000 & $\mathrm{C}$ mud & 1.0 & -13.8 & Bayan Gol \\
\hline 29-TS44* & 954.000 & Cmud D spar P & -1.7 & -15.6 & Bayan Gol \\
\hline 29-TS44* & 954.000 & Cmud D spar P & -1.7 & -15.5 & Bayan Gol \\
\hline $31-T S 45^{*}$ & 963.000 & $\mathrm{C}$ mud ic & -3.0 & -15.5 & Bayan Gol \\
\hline 31-TS45* & 963.000 & $\mathrm{C}$ mud ic & -2.7 & -15.5 & Bayan Gol \\
\hline 33-TS39* & 1000.000 & C wkst ic & -2.4 & -15.3 & Bayan Gol \\
\hline 33-TS39 & 1000.000 & Cwkst ic & -2.5 & -14.6 & Bayan Gol \\
\hline 34-TS47* & 1027.000 & $\mathrm{C}$ mud ic & 1.0 & -18.4 & Bayan Gol \\
\hline 34-TS47* & 1027.000 & $\mathrm{C}$ mud ic & 0.5 & -19.5 & Bayan Gol \\
\hline 34-TS46* & 1030.000 & $\mathrm{C}$ mud ic $\mathrm{Cv}$ & -0.3 & -19.5 & Bayan Gol \\
\hline
\end{tabular}


Table 2 (cont.)

\begin{tabular}{|c|c|c|c|c|c|}
\hline Sample & Height (m) & Lithology & $\delta^{13} \mathrm{C}$ & $\delta^{18} \mathrm{O}$ & Formation \\
\hline 34-TS46* & 1030.000 & $\mathrm{C}$ mud ic $\mathrm{Cv}$ & -0.4 & -20.5 & Bayan Gol \\
\hline 34-TS48 & 1035.000 & $\mathrm{C}$ mud pel & -0.1 & -14.3 & Bayan Gol \\
\hline 34-TS48 & 1035.000 & C mud pel & 0.4 & -14.1 & Bayan Gol \\
\hline
\end{tabular}

Sample numbers for this and following tables give bed number, followed by lab. number. Key for this and following tables: VK = Moscow samples; others are Oxford samples. Asterisks mark samples considered to be 'suspect' (as opposed to 'least-altered') on the basis of $\delta^{18} 0-15 \%, \delta^{13} \mathrm{C}-6.0 \%$, or with conspicuous ferroan carbonate phases in the matrix. Lithology: $\mathrm{C}$, calcite; D or Dol, dolomite; F, ferroan; P, with phosphate; ar, archaeocyathan; arg, argillaceous; b, bituminous; bdst, boundstone; ch, chert; cmb calcimicrobial; fen, fenestrae; glauc, glauconitic; grst, grainstone; ic, intraclasts; lam, laminated; mb, microbial; mspar, microsparitic; mud, mudstone; onc, oncoidal; org, organic-rich; pkst, packstone; pel, peloidal; qtz, quartz grains; spa, spar; strom, stromatolitic; wkst, wackestone; v, veins; vg, vugs.

Table 3. Carbon and oxygen isotopic composition of carbonates in the Salaany Gol section (Fig. 9)

\begin{tabular}{|c|c|c|c|c|c|c|}
\hline \multicolumn{2}{|c|}{ Sample } & \multirow{2}{*}{$\frac{\text { Height }(\mathrm{m})}{1078.000}$} & \multirow{2}{*}{$\begin{array}{l}\text { Lithology } \\
\text { C mud }\end{array}$} & \multirow{2}{*}{$\frac{\delta^{13} \mathrm{C}}{0.5}$} & \multirow{2}{*}{$\frac{\delta^{18} \mathrm{O}}{-9.3}$} & \multirow{2}{*}{$\begin{array}{l}\text { Formation } \\
\text { Bayan Gol }\end{array}$} \\
\hline $5 /$ & $7-1$ & & & & & \\
\hline $5 /$ & $7-45$ & 1082.000 & Calcite & -0.1 & -10.2 & Bayan Gol \\
\hline $5 /$ & $7-2$ & 1088.000 & C ic wkst & 0.1 & -6.7 & Bayan Gol \\
\hline $5 /$ & 7.2 & 1088.000 & $\mathrm{C}$ ic wkst $\mathrm{P}$ & 0.0 & -9.0 & Bayan Gol \\
\hline $5 /$ & $7-44$ & 1089.000 & Calcite & 0.0 & -9.0 & Bayan Gol \\
\hline $5 /$ & $7-3$ & 1090.000 & C strom P & -0.4 & -8.8 & Bayan Gol \\
\hline $5 /$ & $7-4$ & 1100.000 & C ic wkst qtz & 0.4 & -8.7 & Bayan Gol \\
\hline $5 /$ & $7-5$ & 1110.000 & $\mathrm{C}$ ic mb mud & 0.3 & -7.8 & Bayan Gol \\
\hline $5 /$ & $7-6^{*}$ & 1121.000 & C mb mud spar & 0.3 & -15.7 & Bayan Gol \\
\hline $5 /$ & $7-7$ & 1131.000 & $\mathrm{C}$ mb mud spar & 0.2 & -9.0 & Bayan Gol \\
\hline $5 /$ & $7-8$ & 1141.000 & C mb mud Dspar & 0.5 & -8.8 & Bayan Gol \\
\hline $5 /$ & $7-9$ & 1151.000 & C mb mud Dspar & 0.4 & -8.5 & Bayan Gol \\
\hline $5 /$ & $7-10$ & 1161.000 & CD mud & 1.7 & -6.9 & Bayan Gol \\
\hline $5 /$ & $7-10$ & 1161.000 & CD mud & 1.5 & -7.0 & Bayan Gol \\
\hline $5 /$ & $7-11$ & 1171.000 & CD mud & 1.7 & -8.1 & Bayan Gol \\
\hline $5 /$ & $7-11$ & 1171.000 & CD mud & 1.6 & -9.5 & Bayan Gol \\
\hline $5 /$ & $7-12$ & 1183.000 & C cmb mud spar & 1.6 & -7.4 & Bayan Gol \\
\hline $5 /$ & $7-X+1$ & 1183.000 & Cmb mud & 0.3 & -8.8 & Bayan Gol \\
\hline $5 /$ & $7-X+4$ & 1187.000 & Cmb mud & 2.0 & -9.6 & Bayan Gol \\
\hline $7 /$ & $9-13$ & 1353.000 & CD grst & 2.4 & -9.3 & Bayan Gol \\
\hline $7 /$ & $9-13$ & 1353.000 & $\mathrm{CD}$ grst & 2.3 & -9.1 & Bayan Gol \\
\hline $7 /$ & $9-14$ & 1368.000 & C wkst qtz & 1.5 & -11.2 & Bayan Gol \\
\hline $7 /$ & $9-15$ & 1388.000 & C cmb pkst spar & -0.6 & -9.1 & Bayan Gol \\
\hline $7 /$ & $9-16$ & 1398.000 & C mb mud spar & 0.8 & -11.5 & Bayan Gol \\
\hline $7 /$ & $9-17$ & 1408.000 & $\mathrm{C}$ ic mud & -0.3 & -9.8 & Bayan Gol \\
\hline $7 /$ & $9-17$ & 1408.000 & $\mathrm{C}$ arg pkst & -0.7 & -11.2 & Bayan Gol \\
\hline $7 /$ & $9-18$ & 1436.000 & C grst & -1.9 & -14.4 & Bayan Gol \\
\hline 81 & $10-47$ & 1567.000 & Calcite & -0.7 & -14.7 & Bayan Gol \\
\hline 81 & $10-48 *$ & 1568.000 & Calcite & -0.7 & -15.6 & Bayan Gol \\
\hline 81 & $10-49 *$ & 1597.000 & Calcite & -0.5 & -15.3 & Bayan Gol \\
\hline 81 & $10-50$ & 1647.000 & Calcite & -0.4 & -12.5 & Bayan Gol \\
\hline 91 & $11-19$ & 1678.000 & C pel pkst qtz & -1.2 & -14.0 & Bayan Gol \\
\hline $9 /$ & $11-20$ & 1683.000 & C mb mud spar & -0.8 & -9.5 & Bayan Gol \\
\hline $9 /$ & $11-21$ & 1688.000 & C mb mud spar & -1.7 & -8.6 & Bayan Gol \\
\hline $10 /$ & $12-22$ & 1715.000 & C pel pkst spar & -0.0 & -14.5 & Bayan Gol \\
\hline $10 /$ & $12-24^{*}$ & 1752.000 & C mspar P & 3.7 & -15.8 & Bayan Gol \\
\hline $10 /$ & $12-52^{*}$ & 1763.000 & Calcite & 0.7 & -16.7 & Bayan Gol \\
\hline $10 /$ & $12-53^{* *}$ & 1766.000 & Calcite & 0.8 & -15.4 & Bayan Gol \\
\hline $10 /$ & $12-50$ & 1776.000 & Calcite & 1.2 & -12.5 & Bayan Gol \\
\hline $10 /$ & $12-25$ & 1782.000 & $\mathrm{C}$ mb mud qtz & 1.0 & -13.1 & Bayan Gol \\
\hline $10 /$ & $12-26^{*}$ & 1785.000 & C mb mud D & 1.3 & -16.1 & Bayan Gol \\
\hline $10 /$ & $12-27^{*}$ & 1788.000 & $C \mathrm{cmb} \operatorname{mud} \mathrm{P}$ & 1.4 & -16.1 & Bayan Gol \\
\hline $10 /$ & $12-23$ & 1790.000 & $\mathrm{C} \mathrm{cmb} \mathrm{mud} \mathrm{qtz}$ & 0.0 & -14.3 & Bayan Gol \\
\hline $10 /$ & $12-28$ & 1796.000 & C pel pkst qtz & 3.9 & -14.4 & Bayan Gol \\
\hline $10 /$ & $12-29 *$ & 1797.000 & C pel pkst qtz & 4.2 & -16.1 & Bayan Gol \\
\hline $10 /$ & $12-54$ & 1833.000 & $\mathrm{C}$ ic mud $\mathrm{P}$ & -4.6 & -7.2 & Bayan Gol \\
\hline $10 /$ & $12-30$ & 1913.000 & $\mathrm{C} \mathrm{cmb}$ mud $\mathrm{qtz}$ & 1.4 & -14.9 & Bayan Gol \\
\hline $10 \prime$ & $12-31$ & 1914.000 & $\mathrm{C}$ mud qtz & 1.3 & -16.2 & Bayan Gol \\
\hline 111 & $13-32$ & 2037.000 & $C \mathrm{cmb}$ mud & 5.1 & -13.9 & Bayan Gol \\
\hline $11 /$ & $|3-5|$ & 2038.000 & Calcite & 4.1 & -13.3 & Bayan Gol \\
\hline 111 & $13-33 *$ & 2039.000 & Cooid grst & 4.3 & -15.4 & Bayan Gol \\
\hline
\end{tabular}


Table 3. (cont.)

\begin{tabular}{|c|c|c|c|c|c|c|}
\hline \multicolumn{2}{|c|}{ Sample } & \multirow{2}{*}{$\frac{\text { Height }(\mathrm{m})}{2183.000}$} & \multirow{2}{*}{$\begin{array}{l}\text { Lithology } \\
\text { C ic grst }\end{array}$} & \multirow{2}{*}{$\frac{\delta^{13} \mathrm{C}}{4.4}$} & \multirow{2}{*}{$\frac{\delta^{18} \mathrm{O}}{-12.2}$} & \multirow{2}{*}{$\frac{\text { Formation }}{\text { Bayan Gol }}$} \\
\hline 121 & $15-34$ & & & & & \\
\hline 121 & $15-35$ & 2193.000 & C ooid qtz grst & 2.3 & -12.9 & Bayan Gol \\
\hline 121 & $16-36$ & 2201.000 & C ooid qtz grst & 2.1 & -12.2 & Bayan Gol \\
\hline $12 /$ & $16-37$ & 2218.000 & C ic qtz grst & 1.4 & -11.2 & Bayan Gol \\
\hline $12 /$ & $16-38$ & 2228.000 & $\mathrm{C}$ ic qtz grst & 3.4 & -9.5 & Bayan Gol \\
\hline 121 & $16-39$ & 2239.000 & C ic qtz pkst & 0.4 & -10.9 & Bayan Gol \\
\hline 121 & $17-40^{*}$ & 2250.000 & $\mathrm{C}$ mb mud & 0.2 & -16.3 & Bayan Gol \\
\hline $14 \%$ & MKHI9 & 2613.500 & Calcite & -1.1 & -11.8 & Salaany Gol \\
\hline 141 & MKHI9 & 2613.500 & Calcite & -1.0 & -11.5 & Salaany Gol \\
\hline 141 & MKHI8 & 2618.000 & Calcite & -0.5 & -12.5 & Salaany Gol \\
\hline 141 & MKHI8* & 2618.000 & Calcite & -0.8 & -16.5 & Salaany Gol \\
\hline $14 /$ & MKHI7 & 2626.500 & Calcite & -1.1 & -10.4 & Salaany Gol \\
\hline 141 & MKHI7 & 2626.500 & Calcite & -1.0 & -9.8 & Salaany Gol \\
\hline 141 & MKH16 & 2633.500 & Calcite & -1.0 & -9.2 & Salaany Gol \\
\hline 141 & MKH16 & 2633.500 & Calcite & -1.2 & -9.4 & Salaany Gol \\
\hline 141 & MKH1S & 2638.500 & Calcite & -0.9 & -9.1 & Salaany Gol \\
\hline 141 & MKH15 & 2638.500 & Calcite & -1.0 & -10.1 & Salaany Gol \\
\hline 141 & MKHI4 & 2648.500 & Calcite & 0.1 & -10.3 & Salaany Gol \\
\hline 141 & MKHI4 & 2648.500 & Calcite & -0.6 & -10.1 & Salaany Gol \\
\hline 141 & MKHI3 & 2655.500 & Calcite & 2.5 & -8.2 & Salaany Gol \\
\hline 141 & MKHI3 & 2655.500 & Calcite & 0.1 & -9.3 & Salaany Gol \\
\hline 141 & MKHI2 & 2663.500 & Calcite & 0.1 & -11.4 & Salaany Gol \\
\hline 141 & MKHI2 & 2663.500 & Calcite & -0.5 & -11.7 & Salaany Gol \\
\hline 141 & MKHII* & 2669.500 & Calcite & -0.8 & -16.3 & Salaany Gol \\
\hline 141 & MKH11 & 2668.500 & Calcite & 0.2 & -12.6 & Salaany Gol \\
\hline 141 & MKHIO & 2674.000 & Calcite & 1.2 & -11.4 & Salaany Gol \\
\hline 141 & MKHIO & 2674.000 & Calcite & 0.4 & -10.4 & Salaany Gol \\
\hline 141 & MKH9 & 2679.000 & Calcite & -0.2 & -13.5 & Salaany Gol \\
\hline 141 & MKH9* & 2679.000 & Calcite & -0.3 & -15.2 & Salaany Gol \\
\hline 141 & MKH8 & 2684.000 & Calcite & -1.0 & -8.8 & Salaany Gol \\
\hline 141 & MKH8 & 2684.000 & Calcite & -0.9 & -8.4 & Salaany Gol \\
\hline 141 & MKH7 & 2689.000 & Calcite & -1.1 & -9.1 & Salaany Gol \\
\hline 141 & MKH7 & 2689.000 & Calcite & -1.0 & -9.0 & Salaany Gol \\
\hline 141 & MKH6 & 2694.000 & Calcite & -1.1 & -9.6 & Salaany Gol \\
\hline 141 & MKH6 & 2694.000 & Calcite & -1.1 & -9.1 & Salaany Gol \\
\hline 141 & MKH5 & 2698.000 & Calcite & -0.9 & -9.3 & Salaany Gol \\
\hline 141 & MKH5 & 2698.000 & Calcite & -1.0 & -8.6 & Salaany Gol \\
\hline 141 & $\mathrm{MKH} 4$ & 2703.000 & Calcite & -0.9 & -9.6 & Salaany Gol \\
\hline 141 & MKH4 & 2703.000 & Calcite & -1.1 & -10.4 & Salaany Gol \\
\hline 141 & MKH3 & 2708.000 & Calcite & -0.9 & -9.2 & Salaany Gol \\
\hline $14 /$ & MKH3 & 2708.000 & Calcite & -0.8 & -10.1 & Salaany Gol \\
\hline 141 & MKH2 & 2713.000 & Calcite & -1.1 & -9.2 & Salaany Gol \\
\hline $14 /$ & MKH2 & 2713.000 & Calcite & -1.1 & -9.3 & Salaany Gol \\
\hline 141 & MKHI & 2718.000 & Calcite & -0.8 & -7.4 & Salaany Gol \\
\hline 141 & MKHI & 2718.000 & Calcite & -1.0 & -8.7 & Salaany Gol \\
\hline 141 & $20-41$ & 2719.000 & Calcite & 0.7 & -8.2 & Salaany Gol \\
\hline 141 & $21-42$ & 2720.000 & Calcite & -1.2 & -9.7 & Salaany Gol \\
\hline 141 & $21-43$ & 2730.000 & Calcite & -1.5 & -8.4 & Salaany Gol \\
\hline
\end{tabular}


Table 4. Carbon and oxygen isotopic composition of carbonates in the Bayan Gol section 3A (Fig. 8)

\begin{tabular}{|c|c|c|c|c|c|}
\hline Sample & Height & Lithology & $\delta^{13} \mathrm{C}$ & $\delta^{18} \mathrm{O}$ & Formation \\
\hline 3-BAY 3-1 & 25.000 & C bmud & -0.1 & -3.2 & Bayan Gol \\
\hline 3-BAY 1 & 35.000 & $\mathrm{C}$ bmud lam & 0.9 & -1.2 & Bayan Gol \\
\hline 3-BVK-1 & 35.000 & & 1.1 & -8.7 & Bayan Gol \\
\hline 3-BVK-2 & 50.000 & & 4.0 & -8.9 & Bayan Gol \\
\hline 3-BAY 3-2 & 60.000 & $\mathrm{Cb}$ lam wkst & 1.4 & -10.2 & Bayan Gol \\
\hline 4-BAY 4-3 & 70.000 & C b mud spar & 2.1 & -13.2 & Bayan Gol \\
\hline 4-BAY 4-4 & 80.000 & C b lam wkst & 4.6 & -8.6 & Bayan Gol \\
\hline 4-BAY 4-5 & 90.000 & C lam pel mud & 4.1 & -14.9 & Bayan Gol \\
\hline 4-BVK-3 & 92.000 & & 3.5 & -4.2 & Bayan Gol \\
\hline 4-BAY 4-6 & 95.000 & $\mathrm{C}$ mud & 2.4 & -12.4 & Bayan Gol \\
\hline 4-BAY 4-7 & 100.000 & C pel mud & 2.5 & -10.3 & Bayan Gol \\
\hline 4-BAY 4-8 & 110.000 & C pel mud spar & 3.7 & -2.4 & Bayan Gol \\
\hline 4-BAY 4-9 & 120.000 & C pel mud spar & 3.9 & -1.0 & Bayan Gol \\
\hline 4-BVK-4 & 150.000 & & 4.0 & -7.8 & Bayan Gol \\
\hline 4-BVK-5 & 215.000 & & 2.9 & -11.6 & Bayan Gol \\
\hline 4-BVK-6 & 290.000 & & 2.8 & -6.9 & Bayan Gol \\
\hline 5-BAY 5-10 & 300.000 & C strom mud & 2.2 & -8.4 & Bayan Gol \\
\hline 5-BVK-7 & 310.000 & & -0.8 & -3.1 & Bayan Gol \\
\hline $5-B \vee K-8$ & 325.000 & & 1.1 & -2.5 & Bayan Gol \\
\hline 5-BAY 5-11 & 335.000 & $C$ pel mud & 2.2 & -7.6 & Bayan Gol \\
\hline 5-BVK-9 & 355.000 & & 3.0 & -4.5 & Bayan Gol \\
\hline 5-BVK-10 & 365.000 & Dolomite & 3.5 & -4.5 & Bayan Gol \\
\hline 5-BVK-11 & 375.000 & Dolomite & 0.1 & -5.0 & Bayan Gol \\
\hline 6-BAY $\quad 6-12$ & 380.000 & D pel pkst & 1.6 & -10.7 & Bayan Gol \\
\hline $6-B V K-12$ & 385.000 & Dolomite & 2.9 & -4.8 & Bayan Gol \\
\hline 6-BVK-13 & 400.000 & Dolomite & 0.0 & -6.0 & Bayan Gol \\
\hline 6-BVK-14 & 420.000 & Dolomite & 0.2 & -5.8 & Bayan Gol \\
\hline 6-BVK-15 & 430.000 & Dolomite & 3.2 & -7.5 & Bayan Gol \\
\hline $6-B V K-16$ & 450.000 & Dolomite & 3.9 & -5.0 & Bayan Gol \\
\hline 7-BAY 7-15 & 460.000 & D pel pkst & 2.3 & -11.0 & Bayan Gol \\
\hline 7-BVK-17 & 470.000 & Dolomite & 3.0 & -5.0 & Bayan Gol \\
\hline 7-BAY $\quad 7-16$ & 475.000 & D ic pkst & 1.9 & -8.3 & Bayan Gol \\
\hline 7-BCK-18 & 490.000 & Dolomite & 2.9 & -7.6 & Bayan Gol \\
\hline 7-BVK-19 & 510.000 & Dolomite & 2.6 & -5.1 & Bayan Gol \\
\hline 7-BVK-20 & 520.000 & Dolomite & 3.2 & -4.0 & Bayan Gol \\
\hline 7-BVK-21 & 525.000 & Dolomite & 2.9 & -6.0 & Bayan Gol \\
\hline 7-BVK-22 & 535.000 & Dolomite & 2.5 & -3.9 & Bayan Gol \\
\hline 7-BVK-23 & 540.000 & Dolomite & 4.0 & -3.5 & Bayan Gol \\
\hline 7-BVK-24 & 545.000 & Dolomite & 3.0 & -2.4 & Bayan Gol \\
\hline 7-BVK-25 & 560.000 & Dolomite & 3.5 & -3.4 & Bayan Gol \\
\hline 7-BVK-26 & 570.000 & Dolomite & 2.9 & -2.1 & Bayan Gol \\
\hline 7-BVK-27 & 580.000 & Dolomite & 3.2 & -3.2 & Bayan Gol \\
\hline $7-B V K-28$ & 600.000 & Dolomite & 2.8 & -3.8 & Bayan Gol \\
\hline 7-BAY 7-18 & 610.000 & D spar & 3.0 & -2.7 & Bayan Gol \\
\hline 8-BVK-29 & 625.000 & Dolomite & 2.5 & -5.2 & Bayan Gol \\
\hline 8-BVK-30 & 640.000 & Dolomite & 0.6 & -4.8 & Bayan Gol \\
\hline 8-BAY $\quad 8-20$ & 655.000 & D microspar & 2.9 & -2.0 & Bayan Gol \\
\hline 8-BVK-31 & 665.000 & Dolomite & 1.6 & -4.5 & Bayan Gol \\
\hline $9-B V K-32$ & 675.000 & Dolomite & 1.1 & -3.4 & Bayan Gol \\
\hline 9-BAY 9-19 & 685.000 & $\mathrm{D} \mathrm{cmb}$ mud & 1.7 & -1.5 & Bayan Gol \\
\hline 9-BVK-33 & 690.000 & Dolomite & 2.1 & -1.7 & Bayan Gol \\
\hline $11-B V K-34$ & 715.000 & Calcite-Dol & 2.3 & -9.1 & Bayan Gol \\
\hline 11-BVK-35 & 735.000 & Calcite-Dol & 0.5 & -8.9 & Bayan Gol \\
\hline 11-BVK-36 & 750.000 & Calcite-Dol & 0.6 & -8.6 & Bayan Gol \\
\hline 11-BVK-37 & 765.000 & Calcite-Dol & -2.0 & -10.2 & Bayan Gol \\
\hline 11-BVK-38 & 785.000 & Calcite-Dol & -2.8 & -10.0 & Bayan Gol \\
\hline 11-BVK-39 & 795.000 & Calcite-Dol & -2.5 & -8.9 & Bayan Gol \\
\hline 11-BVK-40 & 810.000 & Calcite-Dol & -1.5 & -8.2 & Bayan Gol \\
\hline Il-BVK-4l & 830.000 & Calcite & 0.2 & -13.3 & Bayan Gol \\
\hline $11-B V K-42$ & 845.000 & Calcite & -2.2 & -10.0 & Bayan Gol \\
\hline $11-B V K-43$ & 855.000 & Calcite & -0.4 & -12.5 & Bayan Gol \\
\hline 12-BVK-44* & 865.000 & Calcite & -1.8 & -15.8 & Bayan Gol \\
\hline
\end{tabular}


Table 5. Carbon and oxygen isotopic composition of carbonates in the Bayan Gol section 3B (Fig. 9)

\begin{tabular}{|c|c|c|c|c|c|}
\hline Sample & Height $(\mathrm{m})$ & Lithology & $\delta^{13} \mathrm{C}$ & $\delta^{18} \mathrm{O}$ & Formation \\
\hline 9/B30 & 791.000 & D cmb spar & 2.9 & -4.0 & Tsagaan Oloom \\
\hline $10 / \mathrm{B} 31$ & 792.000 & $\mathrm{CD}$ mspar & 1.8 & -9.3 & Tsagaan Oloom \\
\hline 11/BAY 11-21 & 797.000 & $\mathrm{C}$ pel mud & 1.3 & -7.9 & Tsagaan Oloom \\
\hline $11 / \mathrm{B} 32$ & 816.000 & $\mathrm{CD}$ mud spar & -0.2 & -13.3 & Tsagaan Oloom \\
\hline $11 / \mathrm{B} 33$ & 829.000 & C pel mspar & 0.3 & -7.8 & Tsagaan Oloom \\
\hline $12 / \mathrm{B} 24$ & 834.000 & C mud F spar & -3.3 & -12.8 & Tsagaan Oloom \\
\hline $15 / 11-22$ & 928.000 & $\mathrm{C}$ mud & -0.2 & -7.8 & Tsagaan Oloom \\
\hline $15 / 11-\mathrm{T}$ & 953.000 & C mud & $0-6$ & -12.3 & Tsagaan Oloom \\
\hline $15 / \mathrm{B} 35^{*}$ & 955.000 & C pel mspar & 0.4 & -16.5 & Tsagaan Oloom \\
\hline $15 / \mathrm{B} 36$ & 958.000 & C pel mspar & -0.4 & -8.9 & Tsagaan Oloom \\
\hline 15/B37 & 963.000 & C pel pkst & -2.6 & -11.4 & Tsagaan Oloom \\
\hline $15 / \mathrm{B} 38^{*}$ & 972.000 & C pel pkst & -0.7 & -20.0 & Tsagaan Oloom \\
\hline 16/B39 & 990.000 & C pel mspar & 0.0 & -11.7 & Tsagaan Oloom \\
\hline $16 / \mathrm{B} 40$ & 1000.000 & C pel mspar & 0.5 & -14.6 & Tsagaan Oloom \\
\hline 17/B1 & 1008.000 & C mb mud spar & -2.5 & -12.7 & Bayan Gol \\
\hline 17/B2 & 1013.000 & CD mud spar & -2.6 & -10.3 & Bayab Gol \\
\hline 17/B3 & 1018.000 & CD pel mspar & -2.7 & -7.8 & Bayan Gol \\
\hline $17 / \mathrm{B} 4$ & 1023.000 & CD ic grst & -2.8 & -9.0 & Bayan Gol \\
\hline 17/B5 & 1029.500 & CD pel mspar & -3.4 & -9.0 & Bayan Gol \\
\hline 17/B6 & 1034.500 & CD pel mspar & -3.3 & -8.5 & Bayan Gol \\
\hline $17 / \mathrm{B} 7$ & 1036.500 & CD ic grst & -3.9 & -8.9 & Bayan Gol \\
\hline 17/B8 & 1041.500 & C ic grst & -3.6 & -8.7 & Bayan Gol \\
\hline 18/B9 & 1047.500 & $\mathrm{C}$ ic grst & -3.4 & -7.5 & Bayan Gol \\
\hline $18 / \mathrm{B} 10$ & 1052.500 & $\mathrm{C}$ ic grst & -2.7 & -7.4 & Bayan Gol \\
\hline 18/B11 & 1057.500 & C pel pkst qtz & -2.9 & -9.1 & Bayan Gol \\
\hline $18 / \mathrm{B} 12$ & 1062.500 & $\mathrm{C}$ ic grst & -0.9 & -7.3 & Bayan Gol \\
\hline $18 / \mathrm{B} 14$ & 1082.500 & $\mathrm{C}$ mud glauc & -1.8 & -11.5 & Bayan Gol \\
\hline $18 / \mathrm{B} 15^{*}$ & 1083.500 & $\mathrm{C} \mathrm{cmb} \mathbf{F}$ spar & -0.7 & -9.4 & Bayan Gol \\
\hline 19/B46 & 1125.000 & $\mathrm{C}$ mud qtz pkst & -0.3 & -11.6 & Bayan Gol \\
\hline $19 / B 47$ & 1128.000 & $C$ ic grst & -0.9 & -12.2 & Bayan Gol \\
\hline $19 / \mathrm{B} 48$ & 1148.000 & CD cmb spar & -2.2 & -9.7 & Bayan Gol \\
\hline 19/B49 & 1153.000 & CD wkst spar & -2.2 & -10.4 & Bayan Gol \\
\hline 19/B50 & 1158.000 & C mb mud spar & -2.5 & -9.3 & Bayan Gol \\
\hline 19/B51 & 1163.000 & C cmb spar & -2.2 & -8.4 & Bayan Gol \\
\hline 19/B52 & 1168.000 & CD mspar fen & -2.0 & -8.7 & Bayan Gol \\
\hline 19/B53 & 1172.000 & CD mspar fen & -1.4 & -8.5 & Bayan Gol \\
\hline 19/B54 & 1177.000 & C mb pkst & -1.9 & -8.6 & Bayan Gol \\
\hline 19/B55 & 1182.000 & $\mathrm{C}$ ic grst & -1.9 & -8.5 & Bayan Gol \\
\hline 19/B56 & 1187.000 & C cortoid grst & -1.0 & -9.1 & Bayan Gol \\
\hline 19/B57 & 1192.000 & C cortoid grst & 1.5 & -10.3 & Bayan Gol \\
\hline 19/B58 & 1197.000 & C cortoid grst & -2.3 & -7.8 & Bayan Gol \\
\hline $19 / \mathrm{B} 59$ & 1202.000 & C mb mspar & -2.7 & -9.4 & Bayan Gol \\
\hline 19/B60 & 1207.000 & $\mathrm{C}$ mb fen spar & -3.9 & -10.8 & Bayan $\mathrm{Gol}$ \\
\hline 19/B61 & 1212.000 & $\mathrm{C}$ mb fen spar & -4.0 & -11.5 & Bayan Gol \\
\hline 19/B 62 & 1217.000 & $\mathrm{C}$ mb fen spar & -3.9 & -12.3 & Bayan Gol \\
\hline $21 / \mathrm{B} 63$ & 1270.000 & $\mathrm{C}$ cortoid grst & -0.6 & -10.4 & Bayan Gol \\
\hline $21 / B 64$ & 1276.000 & C pel mspar & -1.0 & -10.1 & Bayan Gol \\
\hline $21 / \mathrm{B} 65$ & 1282.000 & C cmb mud & 0.5 & -8.7 & Bayan Gol \\
\hline 21/B66 & 1288.000 & C mb fen & 1.1 & -8.8 & Bayan Gol \\
\hline $21 / \mathrm{B} 67$ & 1294.000 & C ic grst & -0.7 & -7.5 & Bayan Gol \\
\hline $21 / \mathrm{B} 69$ & 1304.000 & C pel mspar & -2.4 & -8.3 & Bayan Gol \\
\hline $21 / B 70^{*}$ & 1308.000 & $\mathrm{C}$ ic pel grst & -1.9 & -15.7 & Bayan Gol \\
\hline 21/B71* & 1313.000 & C FD pel pkst & -1.1 & -8.8 & Bayan Gol \\
\hline 21/B72 & 1318.000 & $\mathrm{C}$ ic grst Fv & -1.7 & -9.2 & Bayan Gol \\
\hline $21 / \mathrm{B} 73$ & 1323.000 & C i grst spar & -1.4 & -9.6 & Bayan Gol \\
\hline
\end{tabular}

Samples 8/Bay 8-20 to 16/B-40 are from the northern block (1991); 17/B1 to 21/B73 are from the southern block (1993). 
Table 6. Carbon and oxygen isotopic composition of carbonates in the Khevte-Tsakir-Nurruu section (Fig. 10)

\begin{tabular}{|c|c|c|c|c|c|}
\hline Sample & Height (m) & Lithology & $\delta^{13} \mathrm{C}$ & $\delta^{18} \mathrm{O}$ & Formation \\
\hline $0-\mathrm{VK} 1$ & 10.000 & Dolomite & 3.5 & -5.0 & Tsagaan Oloom \\
\hline 0-VK2 & 40.000 & Dolomite & 5.8 & -3.7 & Tsagaan Oloom \\
\hline 0 -VK3 & 50.000 & Dolomite & 3.5 & -4.2 & Tsagaan Oloom \\
\hline 0-VK4 & 70.000 & Dolomite & 4.6 & -5.7 & Tsagaan Oloom \\
\hline $0-$ VK5 & 85.000 & Dolomite & 5.5 & -4.9 & Tsagaan Oloom \\
\hline $0-$ VK 6 & 100.000 & Dolomite & 4.2 & -4.6 & Tsagaan Oloom \\
\hline 0 -VK7 & 120.000 & Dolomite & 3.9 & -5.2 & Tsagaan Oloom \\
\hline 0 -VK8 & 140.000 & Dolomite & 3.5 & -4.4 & Tsagaan Oloom \\
\hline 0-VK9 & 150.000 & Dolomite & 1.0 & -5.2 & Tsagaan Oloom \\
\hline $0-$ VK 10 & 175.000 & Dolomite & 2.0 & -4.1 & Tsagaan Oloom \\
\hline 0 -VK 11 & 200.000 & Dolomite & 3.5 & -4.2 & Tsagaan Oloom \\
\hline $0-V K 12$ & 230.000 & Dolomite & 2.6 & -3.8 & Tsagaan Oloom \\
\hline 0 -VK 13 & 260.000 & Dolomite & 0.0 & -5.5 & Tsagaan Oloom \\
\hline $0-$ VK 14 & 290.000 & Dolomite & 2.0 & -3.6 & Tsagaan Oloom \\
\hline $0-V K 15$ & 330.000 & Dolomite & 2.2 & -5.0 & Tsagaan Oloom \\
\hline $0-\mathrm{VK} 16$ & 380.000 & Dolomite & 0.2 & -7.7 & Tsagaan Oloom \\
\hline 0. VK 17 & 410.000 & Dolomite & -0.5 & -4.8 & Tsagaan Oloom \\
\hline 1-VK18 & 420.000 & Dolomite & 2.5 & -9.4 & Tsagaan Oloom \\
\hline I-KTN2 & 429.000 & D strom $\mathrm{cmb}$ & 3.3 & -1.8 & Tsagaan Oloom \\
\hline 1-KTN3 & 435.000 & $\mathrm{D}$ strom $\mathrm{cmb}$ & 2.8 & -2.3 & Tsagaan Oloom \\
\hline l-KTN4 & 439.000 & D strom $\mathrm{cmb}$ & 3.1 & -2.4 & Tsagaan Oloom \\
\hline 1-VK20 & 440.000 & Dolomite & 2.6 & -1.7 & Tsagaan Oloom \\
\hline 1-KTN5 & 444.000 & D mud pel & 2.7 & -2.5 & Tsagaan Oloom \\
\hline l-VK2l & 450.000 & Dolomite & 3.0 & -3.3 & Tsagaan Oloom \\
\hline l-KTN6 & 452.000 & D mud vg & 2.9 & -0.8 & Tsagaan Oloom \\
\hline 1-KTN7 & 460.000 & D grst in & 3.5 & -0.8 & Tsagaan Oloom \\
\hline $1-V K 22$ & 460.000 & Dolomite & 3.1 & -4.2 & Tsagaan Oloom \\
\hline 1-VK23 & 470.000 & Dolomite & 2.5 & -3.5 & Tsagaan Oloom \\
\hline 1-KTN8 & 470.000 & D grst in & 3.7 & 0.3 & Tsagaan Oloom \\
\hline $4 / 5-$ VK 24 & 520.000 & Calcite & -3.8 & -11.2 & Tsagaan Oloom \\
\hline $4 / 5-\mathrm{T} 4$ & 527.000 & Cpel mud & -2.8 & -10.5 & Tsagaan Oloom \\
\hline 4/5-VK25 & 540.000 & Calcite & -0.9 & -11.2 & Tsagaan Oloom \\
\hline $4 / 5-\mathrm{T} 5$ & 550.000 & C pel mud & -1.6 & -9.4 & Tsagaan Oloom \\
\hline $4 / 5-\mathrm{T} 6$ & 560.000 & C pel mud & -2.3 & -9.9 & Tsagaan Oloom \\
\hline $4 / 5-T 7$ & 570.000 & C pel mud & -1.0 & -9.6 & Tsagaan Oloom \\
\hline 6-T8 & 580.000 & C pel mud & -1.5 & -9.6 & Tsagaan Oloom \\
\hline 6-T9 & 605.000 & C pel mud spar & -2.7 & -8.4 & Tsagaan Oloom \\
\hline 7-KTNI6 & 614.000 & Conc & -2.4 & -9.0 & Tsagaan Oloom \\
\hline 7-KTN15 & 625.000 & C grst & 2.3 & -7.7 & Tsagaan Oloom \\
\hline 7-KTN13 & 645.000 & C grst & 3.0 & -8.4 & Tsagaan Oloom \\
\hline 7-KTN12 & 655.000 & C grst & 3.8 & -7.7 & Tsagaan Oloom \\
\hline 7-KTNII & 665.000 & C pel spar & 4.3 & -6.9 & Tsagaan Oloom \\
\hline 7-KTN10 & 675.000 & C pel spar D & 2.9 & -9.8 & Tsagaan Oloom \\
\hline $8 / 9-\mathrm{T} 13$ & 680.000 & D spar & -2.2 & -12.1 & Tsagaan Oloom \\
\hline $8 / 9-\mathrm{T} 14$ & 687.000 & C pel mud spar & -2.3 & -8.5 & Tsagaan Oloom \\
\hline 8/9-T15 & 693.000 & C pel mud & -2.2 & -7.8 & Tsagaan Oloom \\
\hline $8 / 9-\mathrm{T} 16$ & 703.000 & C pel mud & -2.2 & -7.0 & Tsagaan Oloom \\
\hline $10-T 17$ & 710.000 & C pel mud qtz & -1.6 & -7.3 & Bayan Gol \\
\hline 10-T18 & 717.000 & $\mathrm{Ccmb}$ mud & -1.9 & -8.9 & Bayan Gol \\
\hline 11-T19 & 725.000 & C cmb mud & -2.0 & -8.2 & Bayan Gol \\
\hline $11-\mathrm{T} 20$ & 730.000 & C cmb mud & -3.8 & -9.2 & Bayan Gol \\
\hline $12-\mathrm{T} 21$ & 728.000 & $\mathrm{C}$ mb mud & -1.6 & -9.1 & Bayan Gol \\
\hline $13-\mathrm{T} 22$ & 745.000 & C mb mud & -2.0 & -11.5 & Bayan Gol \\
\hline 13-T23 & 772.000 & Cspar & 1.3 & -11.0 & Bayan Gol \\
\hline $16-T 24$ & 922.000 & C mb mud & -1.4 & -11.2 & Bayan Gol \\
\hline $16-\mathrm{T} 25$ & 950.000 & C mb mud spar & -0.3 & -13.4 & Bayan Gol \\
\hline $16-T 26$ & 1010.000 & $\mathrm{C}$ cmb mud & 0.0 & -9.2 & Bayan Gol \\
\hline
\end{tabular}


Table 7. Carbon and oxygen isotopic composition of carbonates in the Zuune Arts section (Fig. 2) .

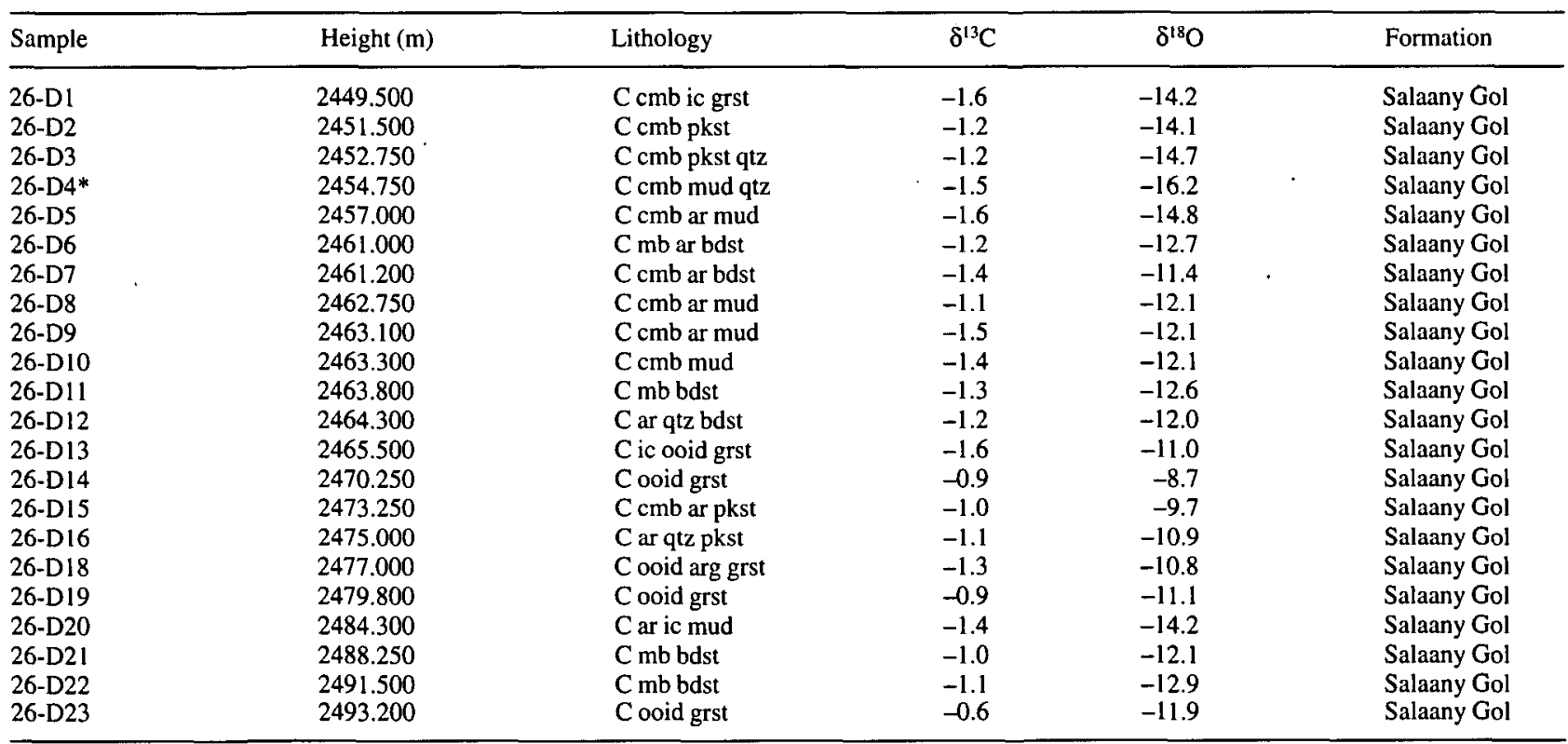

